\title{
ipen
}

AUTARQUIA ASSOCIADA À UNIVERSIDADE DE SÃO PAULO

\section{OXIDAÇÃO DO ETANOL POR ELETROCATALISADOR A BASE DE PLATINA E ESTANHO (PtSn/C-ITO) PREPARADOS PELO MÉTODO DE REDUÇÃO POR BOROHIDRETO DE SÓDIO.}

CONRADO DE VASCONCELOS PEREIRA

Dissertação apresentada como parte dos requisitos para obtenção do Grau de Mestre em Tecnologia Nuclear - Materiais.

Orientador:

Prof. Dr. Almir Oliveira Neto.

São Paulo 
OXIDAÇÃO DO ETANOL POR ELETROCATALISADOR A BASE DE PLATINA E ESTANHO (PtSn/C-ITO) PREPARADOS PELO MÉTODO DE REDUÇÃO POR BOROHIDRETO DE SÓDIO.

\section{CONRADO DE VASCONCELOS PEREIRA}

Dissertação apresentada como parte dos requisitos para obtenção do Grau de Mestre em Tecnologia Nuclear - Materiais.

Orientador:

Prof. Dr. Almir Oliveira Neto.

Versão corrigida

Versão original disponível no IPEN

São Paulo 


\section{AGRADECIMENTOS}

Ao meu orientador Prof. Dr. Almir Oliveira Neto pela amizade, confiança e apoio ao longo de todo este trabalho.

Aos meus pais Fábio Pereira e Eulina de Vasconcelos Pereira e a minha namorada Cloris Macedo pelo apoio e confiança em mim depositados.

Aos professores Dr. Vanderlei Sérgio Bergamaschi e Dr. Jamil M. S. Ayoub pelas orientações e transmissão de conhecimentos em suas disciplinas ministradas.

Aos amigos e profissionais Dr. Júlio Nandenha e Dr. Ricardo Marcelo Piasentin por me ensinarem a manejar os equipamentos de análise na parte experimental.

E por fim aos meus amigos do laboratório do Centro de Células a Combustível a Hidrogênio; Carlos, Monique, Elaine e em especial Guilherme por ter me auxiliado com o tratamento de dados da parte experimental. 


\title{
OXIDAÇÃO DO ETANOL POR ELETROCATALISADOR A BASE DE PLATINA E ESTANHO (PtSn/C-ITO) PREPARADOS PELOS MÉTODOS DE REDUÇÃO POR BOROHIDRETO DE SÓDIO.
}

\author{
Conrado de Vasconcelos Pereira
}

\begin{abstract}
RESUMO
Os eletrocatalisadores de PtSn/C-ITO foram preparados pelo método de redução via borohidreto de sódio com uma carga metálica de $20 \%$ em massa suportados em carbono Vulcan XC72 e óxidos de estanho e índio (ITO) nas seguintes composições; 50:50, 70:30 e 90:10. Os eletrocatalisadores foram submetidos a análises de caracterização por difração de raios-x (DRX), microscopia de transmissão eletrônica (MET), espectroscopia de energia dispersiva de raios $x$ (EDX) e análises eletroquímicas pelas técnicas de voltametria cíclica e de amperometria para os estudos da oxidação eletroquímica em etanol. Nas técnicas eletroquímicas foi utilizado o eletrodo de camada fina porosa onde os eletrocatalisadores foram testados tanto no meio ácido quanto no meio alcalino. Experimentos em célula unitária alimentadas diretamente por etanol foram testados simulando condições reais de operação. As análises eletroquímicas e de caracterização física em meio ácido permitiram comparar o desempenho e estabilidades dos eletrocatalisadores em estudo e também demonstraram os benefícios da adição do estanho e do ITO, tendo como destaque o eletrocatalisador de PtSn/C-ITO 70:30. Em meio alcalino o eletrocatalisador PtSn/C-ITO 50:50 demonstrou ter o melhor desempenho nas análises de voltametria cíclica e amperometria, entretanto, a mesma eficácia não ocorreu nos experimentos em célula unitária o que leva a crer que em meio alcalino o mecanismo de oxidação do etanol sob temperatura e outros parâmetros reais pertinentes à operação da célula precisam ser mudados e/ou estudados.
\end{abstract}

Palavras-chave: Etanol, Estanho (Sn), ITO, Meio ácido, Meio alcalino. 


\title{
ETHANOL OXIDATION USING PLATINUM AND TIIN AS ELECTROCATALYST (PtSn/C-ITO) PREPARED BY SODIUM REDUCTION BOROHYDRIDE METHOD.
}

\section{Conrado de Vasconcelos Pereira}

\begin{abstract}
PtSn /C-ITO electrocatalysts were prepared by the sodium borohydride reduction method with $20 \%$ mass metallic load supported on Vulcan XC72 carbon and tin and indium oxides (ITO) in the following compositions; 50:50, 70:30 and 90:10. The electrocatalysts were subjected to $x$-ray diffraction characterization (XRD), transmission electron microscope (TEM), energy dispersive $x$-ray spectroscopy (EDX) and electrochemical analyzes using cyclic voltammetry and amperometric techniques for studies of ethanol electrochemical oxidation. In the electrochemical techniques the thin porous coating was used where the electrocatalysts were tested in both the acidic and alkaline media. Experiments in unit cell fed directly by ethanol were tested simulating real operating conditions. The electrochemical and physical characterization analyzes in acid medium allowed to compare the performance and stabilities of the electrocatalysts under study and also demonstrated the benefits of the addition of tin and ITO, with emphasis at PtSn/C-ITO 70:30 electrocatalyst. In alkaline media the PtSn/C-ITO 50:50 electrocatalyst demonstrated the best performance in the tests of cyclic voltammetry and amperometry, however, the same efficiency did not happen in the unit cell tests which leads to believe that in alkaline medium the oxidation mechanism of ethanol under temperature and other actual pertinent parameters to cell operation need to be changed and/or studied.
\end{abstract}

Keywords: Ethanol, Tin (Sn), ITO, Acid medium, Alkaline medium. 


\section{SUMÁRIO}

1. INTRODUÇÃO

2. OBJETIVO

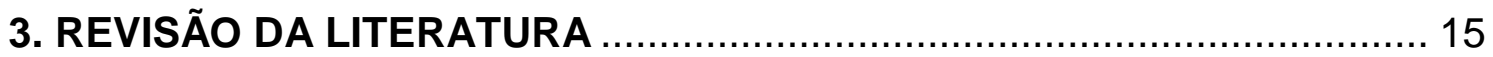

3.1 Breve histórico de células a combustível.............................................. 15

3.1.1 Tipos de Célula a Combustível......................................................... 16

3.2 Células a combustível de etanol direto (DEFC) …….............................. 19

3.2.1 Reação de eletro-oxidação do etanol ................................................. 20

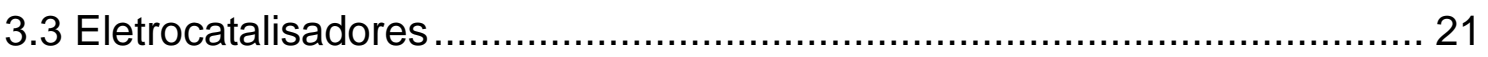

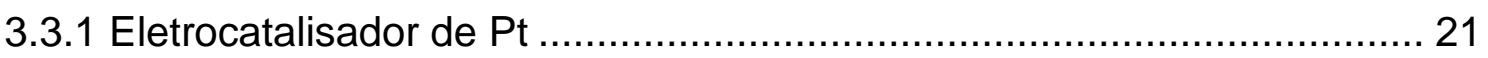

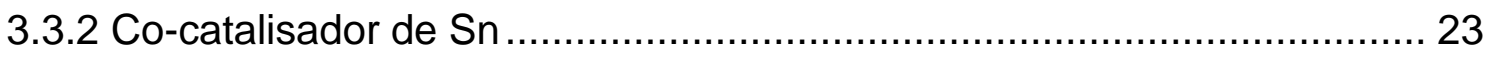

3.3.3 Mecanismo bifuncional e mecanismo eletrônico ..................................... 23

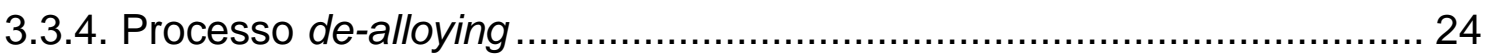

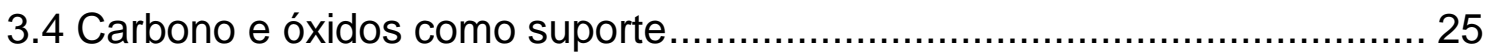

3.5 Métodos de preparação de catalisadores.............................................. 26

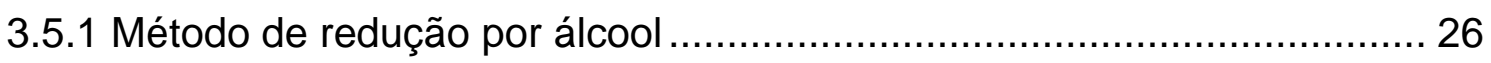

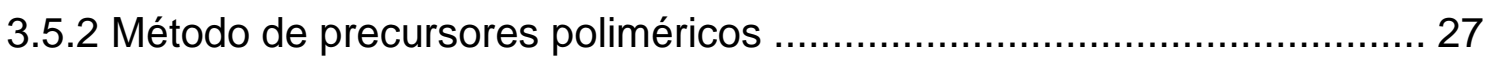

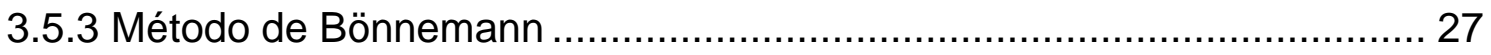

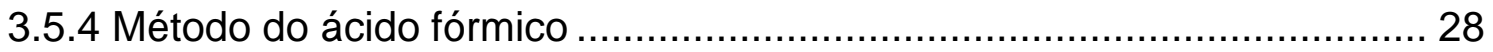

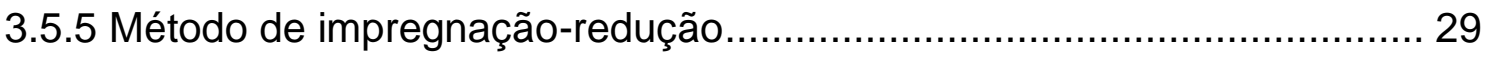

3.5.6 Método de redução por borohidreto de sódio ........................................ 29

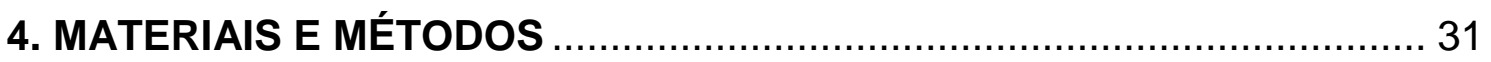

4.1 Preparação e caracterização dos eletrocatalisadores ................................. 31

4.1.1 Preparação do eletrodo de trabalho pela técnica de camada fina porosa31

4.2 Caracterização eletroquímica dos eletrocatalisadores .............................. 32

4.3 Caracterização físico-química dos eletrocatalisadores ............................. 33

4.3.1 Técnica de difração de raios $X(D R X)$................................................ 33

4.3.2 Técnica de microscopia eletrônica de transmissão (MET) …………….. 34

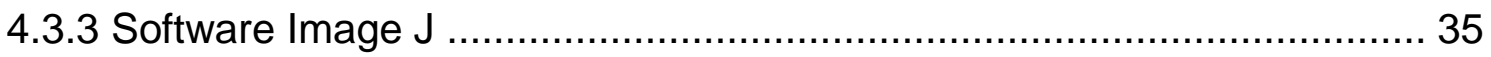

4.3.4 Técnica de espectroscopia de energia dispersiva de raios $\mathrm{x}$ (EDX) ........ 35

4.4 Produção do conjunto membrana-eletrodos (MEA) ……......................... 35

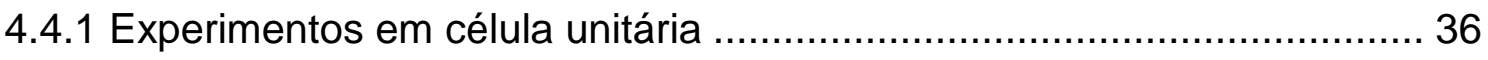




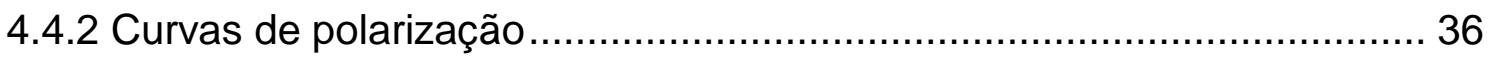

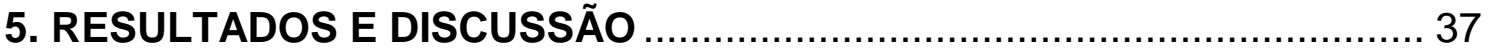

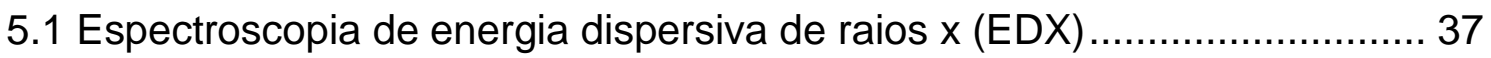

5.1.1 Composição atômica nominal e experimental (EDX) ……….................. 37

5.2 Análise de difração por raios-X (DRX) ................................................... 41

5.3 Microscopia eletrônica de transmissão (MET) ........................................ 44

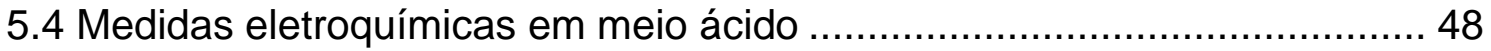

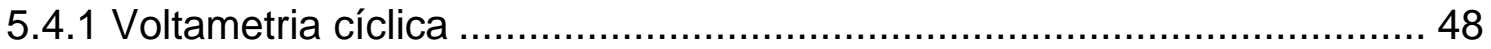

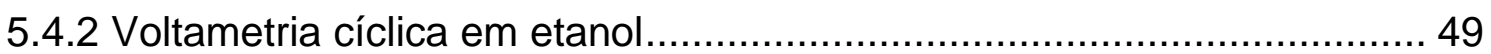

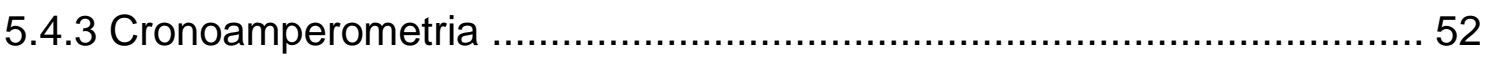

5.5 Medidas em célula combustível unitária em meio ácido ……………....... 54

5.6 Medidas eletroquímicas em meio alcalino............................................... 56

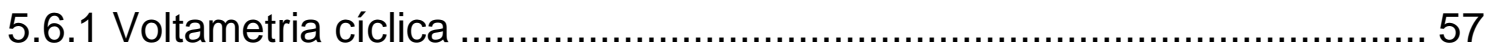

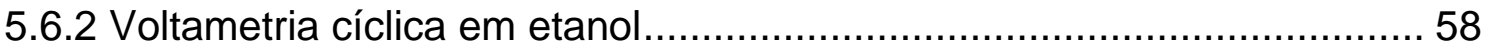

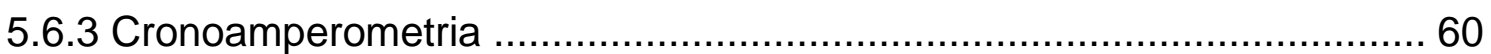

5.7 Medidas em célula combustível unitária em meio alcalino ......................... 62

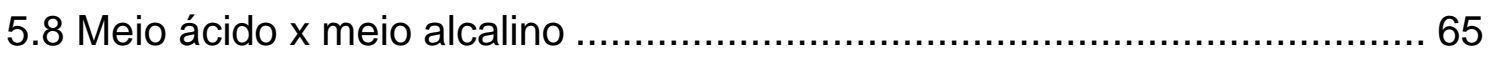

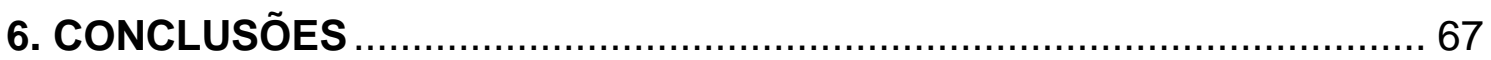

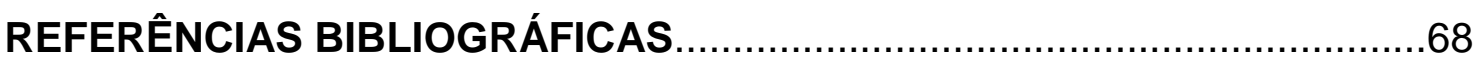




\section{LISTA DE TABELAS}

TABELA 1. Tipos principais de célula a combustível.

TABELA 2. Composição atômica nominal e experimental, obtida pela técnica EDX, para Pt/C, Pt/C-ITO, PtSn/C 70:30, PtSn/C-ITO 50:50, PtSn/C-ITO 70:30 e $\mathrm{PtSn} / \mathrm{C}$-ITO 90:10 sintetizados pelo método de redução via borohidreto de sódio.

TABELA 3. Parâmetro de rede, para os eletrocatalisadores de Pt/C, Pt/C-ITO, $\mathrm{PtSn} / \mathrm{C}$ 70:30, PtSn/C-ITO 50:50, PtSn/C-ITO 70:30 e PtSn/C-ITO 90:10........42 TABELA 4. Estimativa de tamanho de cristalito calculados pela equação de Scherrer, para os eletrocatalisadores de Pt/C, Pt/C-ITO, PtSn/C 70:30, PtSn/CITO 50:50, PtSn/C-ITO 70:30 e PtSn/C-ITO 90:10

TABELA 5. Tamanho mínimo, médio e máximo de partícula para os eletrocatalisadores de Pt/C, Pt/C-ITO, PtSn/C 70:30, PtSn/C-ITO 50:50, PtSn/CITO 70:30 e PtSn/C-ITO 90:10.

TABELA 6. Potenciais de início da oxidação do etanol em meio ácido para os eletrocatlisadores de Pt/C, Pt/C-ITO, PtSn/C 70:30, PtSn/C-ITO 50:50, PtSn/CITO 70:30 e PtSn/C-ITO 90:10.

TABELA 7. Valores de oxidação após 30 minutos de operação pela técnica de cronoamperometria em meio ácido para os eletrocatalisadores de $\mathrm{Pt} / \mathrm{C}, \mathrm{Pt} / \mathrm{C}$ ITO, PtSn/C70:30, PtSn/C-ITO 50:50, PtSn/C-ITO 70:30 e PtSn/C-ITO 90:10 .53

TABELA 8. Potencial de circuito aberto em $\mathrm{mV}$ e densidade de corrente em $\mathrm{mW}$ obtidos pelos experimentos em célula unitária em meio ácido para os eletrocatalisadores de Pt/C, Pt/C-ITO, PtSn/C 70:30, PtSn/C-ITO 50:50, PtSn/CITO 70:30 e $\mathrm{PtSn} / \mathrm{C}$-ITO 90:10 .55

TABELA 9. Potenciais de início da oxidação do etanol em meio alcalino para os eletrocatlisadores de Pt/C, Pt/C-ITO, PtSn/C 70:30, PtSn/C-ITO 50:50, PtSn/CITO 70:30 e PtSn/C-ITO 90:10.

TABELA 10. Valores de oxidação após 1800 segundos de operação pela técnica de cronoamperometria em meio alcalino para os eletrocatalisadores de $\mathrm{Pt} / \mathrm{C}$, 
Pt/C-ITO, PtSn/C70:30, PtSn/C-ITO 50:50, PtSn/C-ITO 70:30 e PtSn/C-ITO 90:10. 61

TABELA 11. Potencial de circuito aberto em $\mathrm{mV}$ e densidade de corrente em $\mathrm{mW}$ obtidos pelos experimentos em célula unitária em meio alcalino para os eletrocatalisadores de Pt/C, Pt/C-ITO, PtSn/C 70:30, PtSn/C-ITO 50:50, PtSn/CITO 70:30 e PtSn/C-ITO 90:10. 63

TABELA 12. Comparação dos valores de oxidação após 30 minutos de operação pela técnica de cronoamperometria do meio ácido com o meio alcalino para os eletrocatalisadores de Pt/C, Pt/C-ITO, PtSn/C70:30, PtSn/C-ITO 50:50, PtSn/CITO 70:30 e PtSn/C-ITO 90:10. 


\section{LISTA DE FIGURAS}

FIGURA 1. Diagrama e estrutura de uma célula PEMFC .................................18

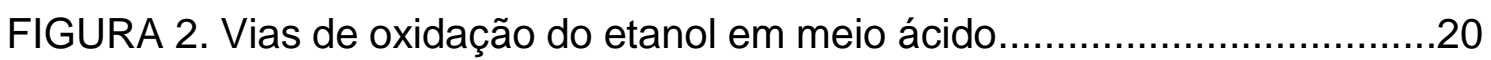

FIGURA 3. Mecanismo de oxidação do etanol em Pt no meio alcalino...............21

FIGURA 4. Curva de Vulcano para adsorção de hidrogênio em diferentes metais

22

FIGURA 5. Imagem obtida por microscópio de varredura para o eletrocatalisador $\mathrm{Pt} / \mathrm{C}$ 38

FIGURA 6. Imagem obtida por microscópio de varredura para o eletrocatalisador $\mathrm{Pt} / \mathrm{C}-\mathrm{ITO}$ 38

FIGURA 7. Imagem obtida por microscópio de varredura para o eletrocatalisador $\mathrm{PtSn} / \mathrm{C}$ 70:30.

FIGURA 8. Imagem obtida por microscópio de varredura para o eletrocatalisador PtSn/C-ITO 50:50.

FIGURA 9. Imagem obtida por microscópio de varredura para o eletrocatalisador PtSn/C-ITO 70:30. 40

FIGURA 10. Imagem obtida por microscópio de varredura para 0 eletrocatalisador PtSn/C-ITO 90:10

FIGURA 11. Difratogramas de raios- $x$ dos eletrocatalisadores $\mathrm{Pt} / \mathrm{C}, \mathrm{Pt} / \mathrm{C}-\mathrm{ITO}$, $\mathrm{PtSn} / \mathrm{C}$ 70:30, PtSn/C-ITO 50:50, PtSn/C-ITO 70:30 e PtSn/C-ITO 90:10. 41

FIGURA 12. Histograma da distribuição dos tamanhos das partículas do eletrocatalisador $\mathrm{Pt} / \mathrm{C}$ e micrografia obtida por MET . .44

FIGURA 13. Histograma da distribuição dos tamanhos das partículas do eletrocatalisador Pt/C-ITO e micrografia obtida por MET. 45

FIGURA 14. Histograma da distribuição dos tamanhos das partículas do eletrocatalisador PtSn/C 70:30 e micrografia obtida por MET. 45

FIGURA 15. Histograma da distribuição dos tamanhos das partículas do eletrocatalisador PtSn/C-ITO 50:50 e micrografia obtida por MET. .46 
FIGURA 16. Histograma da distribuição dos tamanhos das partículas do eletrocatalisador PtSn/C-ITO 70:30 e micrografia obtida por MET ....................46 FIGURA 17. Histograma da distribuição dos tamanhos das partículas do eletrocatalisador PtSn/C-ITO 90:10 e micrografia obtida por MET

FIGURA 18. Voltamogramas cíclicos dos eletrocatalisadores Pt/C, Pt/C-ITO, $\mathrm{PtSn} / \mathrm{C}$ 70:30, PtSn/C-ITO 50:50, PtSn/C-ITO 70:30 e PtSn/C-ITO 90:10 em meio ácido $\mathrm{H}_{2} \mathrm{SO}_{4}$ 0,5 Mol. L-1....

FIGURA 19. Voltamogramas cíclicos dos eletrocatalisadores Pt/C, Pt/C-ITO, $\mathrm{PtSn} / \mathrm{C}$ 70:30, PtSn/C-ITO 50:50, PtSn/C-ITO 70:30 e PtSn/C-ITO 90:10 em meio ácido $\mathrm{H}_{2} \mathrm{SO}_{4}$ 0,5 Mol. $\mathrm{L}^{-1}$ na presença de etanol $1 \mathrm{~mol}$. L $\mathrm{L}^{-1}$ .50 FIGURA 20. Curva cronoamperométrica para os eletrocatalisadores de $\mathrm{Pt} / \mathrm{C}$, $\mathrm{Pt} / \mathrm{C}$-ITO, PtSn/C 70:30, PtSn/C-ITO 50:50, PtSn/C-ITO 70:30 e PtSn/C-ITO 90:10 na presença de $0,5 \mathrm{~mol}$. $\mathrm{L}^{-1} \mathrm{H}_{2} \mathrm{SO}_{4}$ e de etanol 1 mol. $\mathrm{L}^{-1}$. 52 FIGURA 21. Curvas de Polarização para Pt/C, Pt/C-ITO, PtSn/C 70:30, PtSn/CITO 50:50, PtSn/C-ITO 70:30 e PtSn/C-ITO 90:10, fluxo $=1 \mathrm{~mL} \mathrm{~min}{ }^{-1}$ de solução etanol 2 mols L-1. Cátodo alimentado com 2 barr de oxigênio puro. Temperatura de operação da célula $=100^{\circ} \mathrm{C}$. Temperatura de $\mathrm{H}_{2}, \mathrm{O}_{2}=85^{\circ} \mathrm{C}$ .54 FIGURA 22. Voltamogramas cíclicos dos eletrocatalisadores Pt/C, Pt/C-ITO, $\mathrm{PtSn} / \mathrm{C}$-ITO 50:50, PtSn/C 70:30, PtSn/C-ITO 70:30 e PtSn/C-ITO 90:10 em meio alcalino $\mathrm{KOH} 1,0 \mathrm{Mol}$. $\mathrm{L}^{-1}$.....

FIGURA 23. Voltamogramas cíclicos dos eletrocatalisadores Pt/C, Pt/C-ITO, $\mathrm{PtSn} / \mathrm{C}$ 70:30, PtSn/C-ITO 50:50, PtSn/C-ITO 70:30 e PtSn/C-ITO 90:10 em meio alcalino $\mathrm{KOH} 1,0 \mathrm{Mol}$. L $\mathrm{L}^{-1}$ na presença de etanol $1 \mathrm{~mol} \mathrm{~L}^{-1}$ .58 FIGURA 24. Curva cronoamperométrica para os eletrocatalisadores de $\mathrm{Pt} / \mathrm{C}$, Pt/C-ITO, PtSn/C 70:30, PtSn/C-ITO 50:50, PtSn/C-ITO 70:30 e PtSn/C-ITO 90:10 na presença de 1,0 mol. $\mathrm{L}^{-1}$ de $\mathrm{KOH}$ e etanol $1 \mathrm{~mol}^{\mathrm{L}} \mathrm{L}^{-1}$ 60 FIGURA 25. Curvas de Polarização para Pt/C, Pt/C-ITO, PtSn/C 70:30, PtSn/C-

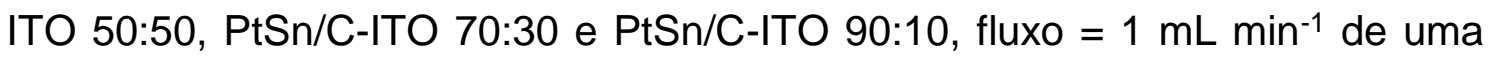
solução etanol $2 \mathrm{~mol} \mathrm{~L}^{-1}$ de $\mathrm{KOH}$ na presença de 2,0 $\mathrm{mol} \mathrm{L}^{-1}$ de etanol. O cátodo foi mantido sob fluxo de oxigênio de $150 \mathrm{~mL}$ min-1. Temperatura de operação da célula $=100^{\circ} \mathrm{C}$. Temperatura de $\mathrm{H}_{2}, \mathrm{O}_{2}=85^{\circ} \mathrm{C}$ 


\section{INTRODUÇÃO}

A energia é uma das chaves para os grandes objetivos do homem e da sua prosperidade para um mundo melhor. Desde a época das cavernas 0 homem tem usado a energia para sua alimentação, sobrevivência e melhoria da qualidade de vida como um todo. Com o passar dos anos a raça humana tem buscado o bem-estar material e isto tem sido em grande parte proveniente das várias formas de energia, como na utilização do carvão, do petróleo e da eletricidade [1-2].

Hoje com a modernidade e o crescimento da população no planeta, a demanda de energia é extremamente grande fazendo com que a humanidade venha a buscar meios mais eficientes e menos poluentes para suprir as necessidades humanas e não agredir de forma degenerativa o planeta.

As células a combustível são uma alternativa promissora no mercado de energia, pois possuem elevada eficiência, baixo nível de ruído, pouca ou nenhuma emissão de poluentes e podem ser utilizadas em aplicações estacionárias, veículos e aparelhos portáteis [2-3].

Uma das células a combustível mais utilizadas é a PEMFC: Proton Exchange Membrane Fuel Cell. "Célula a combustível de membrana polimérica condutora de prótons" [3]. As células a combustível do tipo PEMFC mais eficientes utilizam hidrogênio como combustível e o uso do hidrogênio puro apresenta alguns inconvenientes, como o seu transporte, armazenamento e distribuição. No Brasil o uso do hidrogênio como combustível traria a necessidade de uma nova estrutura logística e física, ou seja, a construção de postos aptos a distribuir ou gerar o hidrogênio, como também a criação de normas e legislação para o manuseio do hidrogênio seriam requeridas. Portanto a utilização de um combustível líquido é mais apropriada em virtude de sua produção, armazenagem e distribuição, fazendo com que toda a estrutura atual seja aproveitada. A PEMFC possui algumas subdivisões devido ao uso de combustíveis alternativos ao hidrogênio. Dentre elas podemos destacar a DMFC; Direct Methanol Fuel Cell (célula a combustível de metanol direto) e a DEFC; Direct Ethanol Fuel Cell (célula a combustível de etanol direto) [4,5]. Ambas 
possuem estrutura similar a PEMFC, contudo, utilizam como combustível o metanol (DMFC) ou etanol (DEFC) onde estes combustíveis sofrem oxidação no ânodo [3].

Dentre todos os eletrocatalisadores binários estudados até o momento verificou-se que os eletrocatalisadores $\mathrm{PtSn} / \mathrm{C}$ são mais ativos que os demais eletrocatalisadores binários na oxidação eletroquímica do etanol [7-14], no entanto os principais produtos da eletro-oxidação do etanol sobre os eletrocatalisadores $\mathrm{PtSn} / \mathrm{C}$ ainda são acetaldeído e ácido acético e por este fator há ainda a necessidade do desenvolvimento de novos eletrocatalisadores.

Uma segunda proposta tem sido o uso de óxidos como suporte em eletrocatalisadores para células a combustível. Park e colaboradores [20] mostraram que o óxido de índio e estanho (ITO) utilizado como suporte de nanopartículas de $\mathrm{Pt}$ foi mais ativo para a oxidação do metanol em relação $\mathrm{Pt} / \mathrm{C}$, enquanto que Parrondo e colaboradores [16] mostraram nanopartículas de Pt/C e $\mathrm{In}_{2} \mathrm{O}_{3}$ com uma atividade superior a $\mathrm{Pt} / \mathrm{C}$, o aumento da atividade pode ser atribuída aos efeitos de $\ln _{2} \mathrm{O}_{3}$ adjacentes a Pt (efeito bifuncional).

Assim, neste trabalho buscou-se desenvolver eletrocatalisadores binários formados por PtSn/C-ITO para emprego no estudo da oxidação eletroquímica do etanol. 


\section{OBJETIVO}

O objetivo deste trabalho consiste na preparação e na caracterização de eletrocatalisadores $\mathrm{PtSn} / \mathrm{C}$-ITO em diferentes composições atômicas pelo método de redução via borohidreto de sódio para o estudo da oxidação em etanol em meio ácido e alcalino. 


\section{REVISÃO DA LITERATURA}

\subsection{Breve histórico de células a combustível}

A tecnología de células a combustível foi descoberta muito antes do desenvolvimento da eletroquímica, em 1839 pelo físico britânico William Robert Grove (1811-1896). [21]

A primeira célula a combustível, era composta por duas tiras de platina imersas em água acidulada; a parte superior de uma delas era exposta ao hidrogênio, e a outra ao oxigênio. A descoberta permaneceu por muitos anos como uma curiosidade científica. Em 1880, dois químicos ingleses Ludwing Mond e Carl Langer, desenvolveram uma célula a combustível de maior durabilidade empregando um monocondutor poroso para manter o eletrólito [21].

No início do século XX Fritz Haber, Walther H. Nernst, e Edmond Bauer experimentaram células com eletrólito sólido. Devido ao progresso limitado e ao elevado custo os estudos foram esquecidos [21].

No final dos anos de 1930 e até após a segunda guerra mundial, Francis Thomas Bacon e colaboradores, desenvolveram uma célula a combustível com eletrólito alcalino e os eletrodos de difusão gasosa, onde o combustível gasoso em contato com um dos lados do eletrodo é efetivamente mantido sob controle e em contato com um eletrólito aquoso do outro lado [21].

Durante as décadas de 50 e 60. A National Aeronautics and Space Administration (NASA), depois de descartar a possibilidade de uso de reatores nucleares por serem de alto risco, as baterias por serem pesadas e de vida curta e a energia fotovoltaica de difícil manejo para uso em missão espacial, decidiu investir maciçamente no desenvolvimento de um sistema compacto de geração de eletricidade, a célula combustível. Nos dias de hoje as células a combustível produzem com segurança energia e água, e foram utilizadas em marcos importantes da história espacial como nas missões Apollo e Space Shuttle [21]. 


\subsubsection{Tipos de Célula a Combustível}

As células a combustível operam de maneira contínua oxidando um combustível no ânodo e reduzindo oxigênio usualmente do ar no cátodo, elas transformam energia química em calor e energia elétrica. Este processo completa-se pela circulação dos elétrons no circuito externo até produção de trabalho elétrico [4]. Sua eficiência teórica é determinada pelo quociente entre a energia livre da reação " $\Delta G$ " e a entalpia da reação " $\Delta H$ " [3-4].

Os principais tipos de células a combustível utilizadas são: AFC: Alkaline Fuel Cell "célula a combustível alcalina" com faixa de temperatura de operação de $60^{\circ} \mathrm{C}$ à $90^{\circ} \mathrm{C}$. PEMFC: Proton Exchange Membrane Fuel Cell "célula a combustível de membrana polimérica condutora de prótons" com faixa de temperatura de operação de $80^{\circ} \mathrm{C}$ à $90^{\circ} \mathrm{C}$. PAFC: Phosforic Acid Fuel Cell "célula combustível de ácido fosfórico" com faixa de temperatura de operação de $160^{\circ} \mathrm{C}$ à 200ㄷ․ MCFC: Molten Carbonate Fuel Cell " célula combustível de carbonato fundido" com faixa de temperatura de operação de $650^{\circ} \mathrm{C}$ à $700^{\circ} \mathrm{C}$ e SOFC: Solide Oxide Fuel Cell "célula combustível de óxido sólido" com faixa de temperatura de operação de $800^{\circ} \mathrm{C}$ à $1000^{\circ} \mathrm{C}$. Sendo as três primeiras classificadas como de baixa temperatura de operação e as duas últimas como de alta temperatura de operação. [3]

A TAB.1 descreve as diferenças com mais detalhes entre as principais células a combustível atualmente usadas. 
TABELA 1. Tipos principais de célula a combustível [3]

\begin{tabular}{|c|c|c|c|c|c|}
\hline Tipo & $\begin{array}{c}\text { Eletrólito } \\
\text { Espécie } \\
\text { transportada } \\
\text { e espessura }\end{array}$ & $\begin{array}{c}\text { Faixa de } \\
\text { Temperatura } \\
\left({ }^{\circ} \mathrm{C}\right)\end{array}$ & $\begin{array}{l}\text { Principais } \\
\text { Vantagens }\end{array}$ & $\begin{array}{c}\text { Principais } \\
\text { Desvantagens }\end{array}$ & Aplicações \\
\hline $\begin{array}{l}\text { Alcalina } \\
\text { AFC }\end{array}$ & $\begin{array}{l}\mathrm{KOH} \\
\left(\mathrm{OH}^{-}\right) \\
2 \mathrm{~mm}\end{array}$ & $60-90$ & Alta eficiência. & $\begin{array}{l}\text { Sensível a } \mathrm{CO}_{2} . \\
\text { Remoção de água. } \\
\text { Gases ultrapuros. }\end{array}$ & $\begin{array}{l}\text { Espaçonaves. } \\
\text { Aplicações } \\
\text { especiais. }\end{array}$ \\
\hline $\begin{array}{l}\text { Membrana } \\
\text { PEMFC }\end{array}$ & $\begin{array}{c}\text { Polímero } \\
\text { Náfion } \\
\left(\mathrm{H}_{3} \mathrm{O}^{+}\right) \\
\text {Aprox. 1mm }\end{array}$ & $80-90$ & $\begin{array}{l}\text { Altas densidades } \\
\text { de potência e } \\
\text { eficiências. } \\
\text { Operação flexível. } \\
\text { Robustas. }\end{array}$ & $\begin{array}{l}\text { Custo da } \\
\text { membrana e } \\
\text { catalisador. } \\
\text { Contaminação da } \\
\mathrm{Pt} \text { por co. } \\
\text { (tolerância máxima } \\
\text { até } 100 \text { ppm) }\end{array}$ & $\begin{array}{l}\text { Veículos. } \\
\text { Espaçonaves. } \\
\text { Unidades } \\
\text { estacionárias. }\end{array}$ \\
\hline $\begin{array}{l}\text { Ácido } \\
\text { Fosfórico } \\
\text { PAFC }\end{array}$ & $\begin{array}{c}\mathrm{H}_{3} \mathrm{PO}_{4} \\
\left(\mathrm{H}_{3} \mathrm{O}^{+}\right) \\
\text {Matriz } \mathrm{SiC} ; \\
0,1 \mathrm{~mm}\end{array}$ & $160-200$ & $\begin{array}{l}\text { Maior } \\
\text { desenvolvimento } \\
\text { tecnológico. }\end{array}$ & $\begin{array}{l}\text { Controle da } \\
\text { porosidade do } \\
\text { eletrodo. } \\
\text { Sensibilidade a CO. } \\
\text { (tolerância máxima } \\
\text { até 1\%) } \\
\text { Eficiência limitada } \\
\text { pela corrosão. }\end{array}$ & $\begin{array}{l}\text { Unidades } \\
\text { estacionárias. } \\
\text { Cogeração } \\
\text { eletricidade/ } \\
\text { Calor. }\end{array}$ \\
\hline $\begin{array}{l}\text { Carbonatos } \\
\text { Fundidos } \\
\text { MCFC }\end{array}$ & $\begin{array}{c}\text { Carbonatos } \\
\text { fundidos } \\
\left(\mathrm{CO}_{3}{ }^{2-}\right) \\
\text { Matriz } \mathrm{LiAlO}_{2} \\
0,5-1,0 \mathrm{~mm}\end{array}$ & $650-700$ & $\begin{array}{l}\text { Tolerância a } \\
\mathrm{CO} / \mathrm{CO}_{2} . \\
\text { Eletrodos a base } \\
\text { de Ni. } \\
\text { Reforma interna } \\
\text { na célula. }\end{array}$ & $\begin{array}{l}\text { Problemas de } \\
\text { Materiais. } \\
\text { Necessidade de } \\
\text { reciclagem de } \mathrm{CO}_{2} \text {. } \\
\text { Interface trifásica } \\
\text { de difícil controle. } \\
\text { Corrosão }\end{array}$ & $\begin{array}{l}\text { Unidades } \\
\text { estacionárias. } \\
\text { Cogeração } \\
\text { eletricidade/ } \\
\text { Calor. }\end{array}$ \\
\hline $\begin{array}{l}\text { Cerâmicas } \\
\text { SOFC }\end{array}$ & $\begin{array}{c}\mathrm{ZrO}_{2} \\
\left(\mathrm{O}_{2}^{-}\right) \\
50-100 \mu \mathrm{m}\end{array}$ & $800-1000$ & $\begin{array}{l}\text { Alta eficiência. } \\
\text { Cinética } \\
\text { favorável. } \\
\text { Reforma interna. }\end{array}$ & $\begin{array}{l}\text { Problemas de } \\
\text { materiais. } \\
\text { Problemas de } \\
\text { expansão térmica. } \\
\text { Necessidade de } \\
\text { pré-reforma. }\end{array}$ & $\begin{array}{l}\text { Unidades } \\
\text { estacionárias. } \\
\text { Cogeração }\end{array}$ \\
\hline
\end{tabular}


Dentro da tecnologia de células a combustível podemos destacar as células do tipo PEMFC (FIG.1) por apresentarem maior flexibilidade quanto as suas aplicações, podendo ser utilizadas em operações portáteis, estacionárias e veiculares, sendo esta última aplicação um destaque motivador de pesquisas principalmente por empresas automobilísticas [3, 23]. Este tipo de célula apresenta ânodo e cátodo compostos por nanopartículas de platina ancoradas em carbono, camada difusora de tecido ou papel de carbono parcialmente teflonadas e a membrana polimérica condutora Náfion como eletrólito [23].

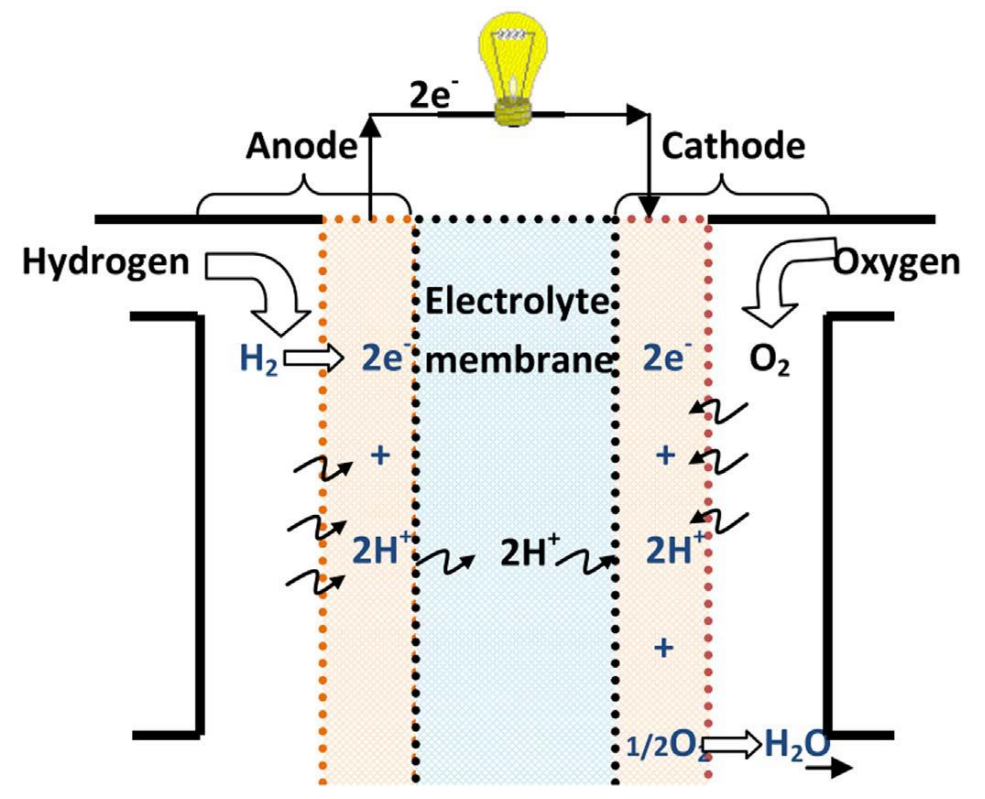

Figura 1. Diagrama e estrutura de uma célula PEMFC [22]

Usando-se hidrogênio e oxigênio em uma célula a combustível não há emissão de poluentes e o produto final desta reação é água e calor conforme as equações 1,2 e 3 [3].

Ânodo: $2 \mathrm{H}_{2(\mathrm{~g})}+4 \mathrm{H}_{2} \mathrm{O}_{(l)} \rightarrow 4 \mathrm{H}_{3} \mathrm{O}^{+}(\mathrm{l})+4 \mathrm{e}^{-}$

Cátodo: $\mathrm{O}_{2(\mathrm{~g})}+4 \mathrm{H}_{3} \mathrm{O}^{+}(\mathrm{l})+4 \mathrm{e}^{-} \rightarrow \mathrm{H}_{2} \mathrm{O}_{(l)}$

Global: $2 \mathrm{H}_{2(\mathrm{~g})}+\mathrm{O}_{2(\mathrm{~g})} \rightarrow 2 \mathrm{H}_{2} \mathrm{O}_{(l)}$

A produção de hidrogênio existente possui ainda um alto custo e pode ser obtido de duas maneiras, através de reforma e da eletrólise da água [24]. A forma 
mais limpa de se produzir hidrogênio é através da eletrólise da água, entretanto por motivos econômicos a produção de hidrogênio a partir de reforma é a mais viável para a produção deste combustível. [24,25].

O uso do hidrogênio puro apresenta alguns inconvenientes, como o seu transporte, armazenamento e distribuição, diante destes fatores há uma tendência ao uso de combustíveis líquidos como no uso de células de metanol direto (DMFC) e células de etanol direto (DEFC) [26].

\subsection{Células a combustível de etanol direto (DEFC)}

O metanol tem sido o álcool mais estudado para aplicação em células a combustível, ele produz densidades de potência da ordem de $350 \mathrm{~mW} \mathrm{~cm}^{-2}$, entretanto, seu uso em células do tipo DMFC apresenta alguns inconvenientes como o fato de ser um combustível tóxico, inflamável e ser extraído principalmente pela destilação destrutiva de madeiras [3,36,37].

O Brasil é o maior produtor de etanol do mundo quando consideramos o uso de cana de açúcar e segundo o ministério da agricultura a projeção para 2019 é que se produzam 58,8 bilhões de litros deste combustível [6]. Este é um dado que demonstra a abundância do etanol e de certa forma atesta a sua viabilidade de estudo em células DEFC.

As vantagens do etanol sobre o hidrogênio são o armazenamento menos perigoso, o manejo por se encontrar no estado líquido e a obtenção por biomassa, esta última tratando-se do Brasil a cana-de-açúcar. Suas desvantagens são objetos de estudo, ou seja, o uso deste combustível produz densidades de correntes menores da ordem de $100 \mathrm{~mW} \mathrm{~cm}^{-2}$ por conta de uma maior demanda de energia para se quebrar a ligação C-C da molécula de etanol. [3]

A formação de intermediários fortemente adsorvidos também são um problema em células a combustível do tipo DEFC, pois desativam o eletrocatalisador diminuindo a densidade de corrente gerada. [3-4]. Portanto o estudo e desenvolvimento de novos eletrocatalisadores neste campo de pesquisa ocorrem afim de se obter atividades eletródicas mais favoráveis no uso de etanol como combustível. 


\subsubsection{Reação de eletro-oxidação do etanol}

O mecanismo de oxidação do etanol pode ocorrer por maneiras diferentes conforme a FIG.2

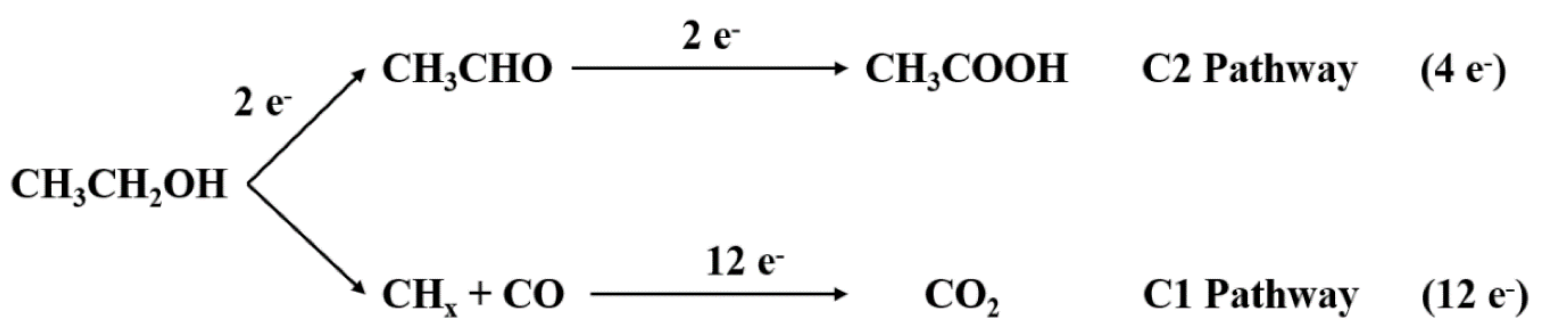

Figura 2. Vias de oxidação do etanol em meio ácido [15]

$\mathrm{Na}$ via $\mathrm{C} 1$ o etanol é completamente oxidado a $\mathrm{CO}_{2}$ fornecendo 12 elétrons enquanto na via $\mathrm{C} 2$ o etanol é parcialmente oxidado a ácido acético fornecendo 4 elétrons ou a acetaldeído fornecendo 2 elétrons. As equações 4,5,6,7 e 8 mostram com mais detalhes os processos que podem ocorrer [15].

$$
\begin{aligned}
& \text { Mecanismo } 12 \mathrm{e}^{-} \\
& \mathrm{CH}_{3} \mathrm{CH}_{2} \mathrm{OH}+3 \mathrm{H}_{2} \mathrm{O} \rightarrow 2 \mathrm{CO}_{2}+12 \mathrm{H}^{+}+12 \mathrm{e}^{-} \\
& \mathrm{CH}_{3} \mathrm{CH}_{2} \mathrm{OH}+5 \mathrm{H}_{2} \mathrm{O} \rightarrow 2 \mathrm{HCO}_{3}{ }^{-}+14 \mathrm{H}^{+}+12 \mathrm{e}^{-} \\
& \mathrm{CH}_{3} \mathrm{CH}_{2} \mathrm{OH}+5 \mathrm{H}_{2} \mathrm{O} \rightarrow 2 \mathrm{CO}_{3}{ }^{2-}+16 \mathrm{H}^{+}+12 \mathrm{e}^{-}
\end{aligned}
$$

Mecanismo $4 \mathrm{e}^{-}$e $2 \mathrm{e}^{-}$

$\mathrm{CH}_{3} \mathrm{CH}_{2} \mathrm{OH}+\mathrm{H}_{2} \mathrm{O} \rightarrow \mathrm{CH}_{3} \mathrm{COOH}+4 \mathrm{H}^{+}+4 \mathrm{e}^{-}$

$\mathrm{CH}_{3} \mathrm{CH}_{2} \mathrm{OH} \rightarrow \mathrm{CH}_{3} \mathrm{CHO}+2 \mathrm{H}^{+}+2 \mathrm{e}^{-}$

Estudos com técnicas espectroscópicas mostram que em meio alcalino predomina-se a formação de acetato conforme FIG.3 [27] 


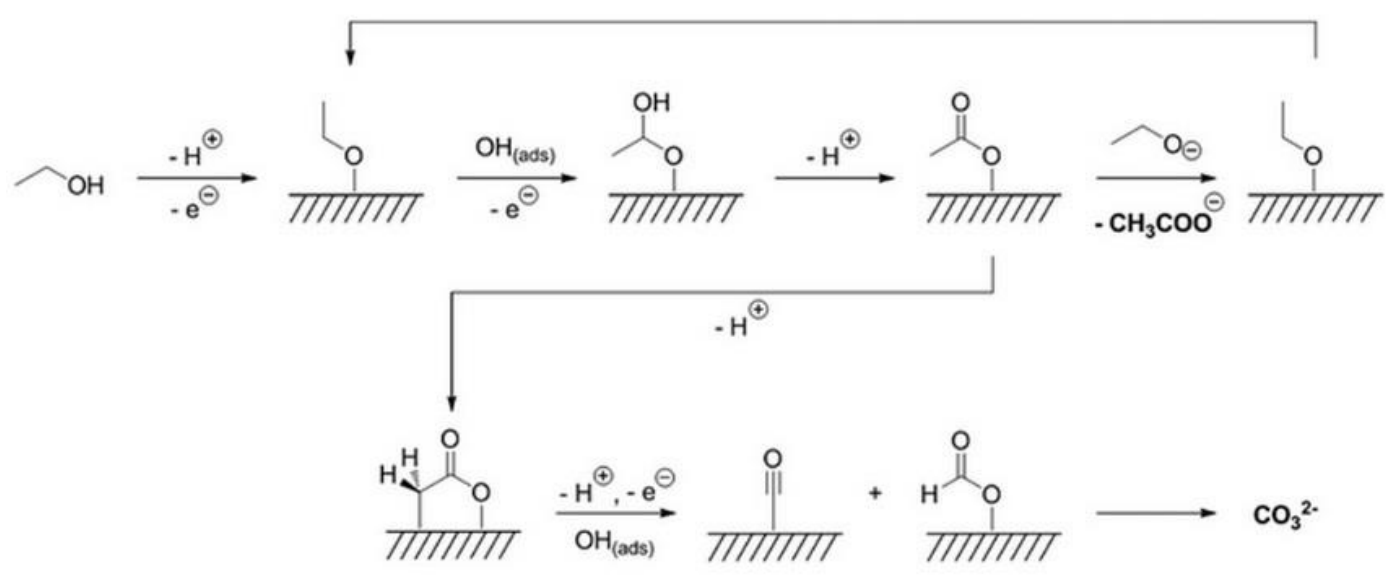

Figura 3. Mecanismo de oxidação do etanol em Pt no meio alcalino [27]

\subsection{Eletrocatalisadores}

A definição de eletrocatálise pode ser entendida como uma reação eletroquímica que é processada com velocidades diferentes dependendo do substrato eletródico quando em um mesmo sobrepotencial. [4, 33].

Define-se eletrocatalisador como um catalisador que participa em reações eletroquímicas. Eles modificam e aumentam a taxa de reações químicas sem serem consumidos no processo [4,33].

Os eletrocatalisadores têm sido utilizados neste processo para aumentar a velocidade das reações eletródicas e proporcionar um aumento de potencial nas células [3].

\subsubsection{Eletrocatalisador de Pt}

O uso de metais nobres para a aplicação em células a combustível está associado a curva de Vulcano FIG.4, onde a platina se mostra como um eficiente eletrocatalisador para o processo de oxidação do hidrogênio e demais reações, pois possui densidade de corrente de troca e entalpia de adsorção relativamente altas [3]. 


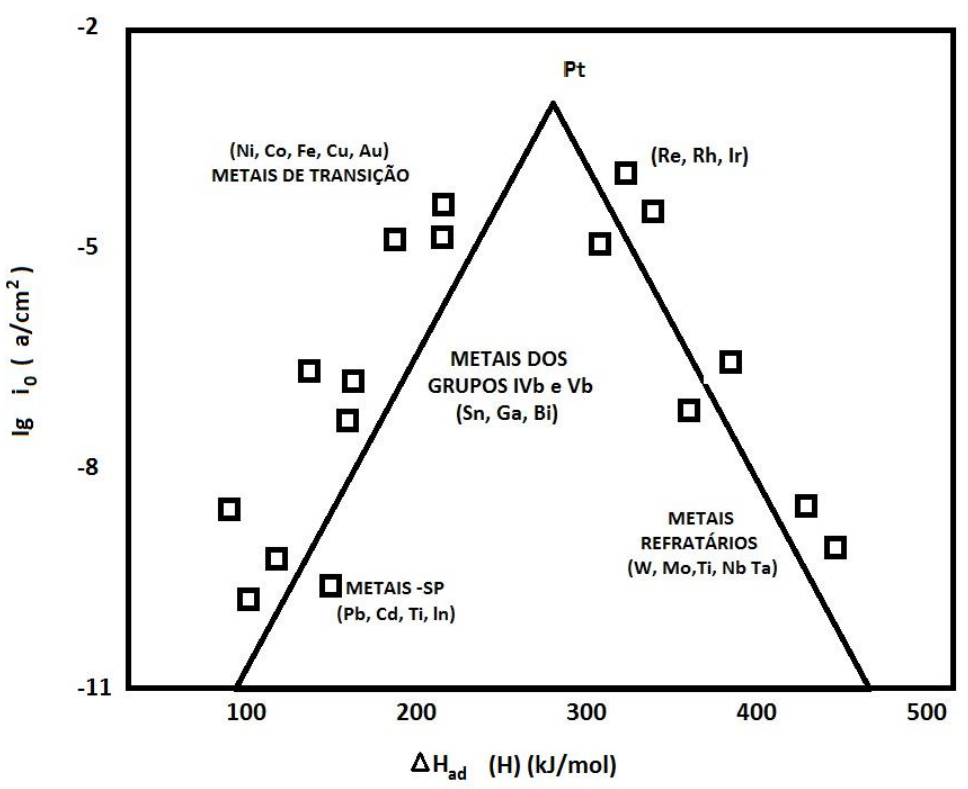

Figura 4. Curva de Vulcano para adsorção de hidrogênio em diferentes metais [3]

A platina é um metal nobre de alto valor no mercado, seu custo é sem dúvida um fator a se considerar, portanto ao incorporar o uso deste metal para a produção de eletrocatalisadores, busca-se adaptar a mínima quantidade possível a uma condição máxima de aproveitamento cinético, o que tem ocorrido com a evolução dos estudos na área. A platina passou a constituir menos custos aos sistemas de célula a combustível devido ao seu uso em tamanho nanométrico. Nanopartículas já são usadas entre 2 e $10 \mathrm{~nm}$ com dispersões de $0,2 \mathrm{mg} \mathrm{cm}^{-2} \mathrm{e}$ áreas específicas da ordem de $60 \mathrm{~m}^{2} \mathrm{~g}^{-1}[3,32,34]$.

O desempenho do eletrocatalisador de platina diminui na presença de $\mathrm{CO}$, $\mathrm{CH}_{\mathrm{x}}$ ou outras espécies contendo um ou dois átomos de carbono. As células a combustível de baixa temperatura de operação sofrem com o uso de combustíveis primários, como: o metanol, o etanol e o gás natural. $O$ hidrogênio gerado na oxidação destes combustíveis contém $\mathrm{CO}$ em valores que ultrapassam a tolerância de $10 \mathrm{ppm}$, podendo chegar até $100 \mathrm{ppm}$ ocasionando o envenenamento total da célula [3,35,38,39]. Para que os intermediários possam ser liberados dos sítios ativos da platina, são necessários elevados potenciais. Em potenciais iguais ou superiores a $0,7 \mathrm{~V}$ vs $E R H$ ocorre a formação das espécies oxigenadas quem atuam como fontes de oxigênio para a oxidação completa a $\mathrm{CO}_{2}$. [38,39]. 
A platina tem sido empregada como o principal eletrocatalisador para a oxidação eletroquímica do etanol em meio ácido, como visto, a formação de intermediários diminui a atividade catalítica deste eletrocatalisador e por conseqüência é necessário adicionar um co-catalisador a platina.

\subsubsection{Co-catalisador de Sn}

Alguns elementos químicos como o $\mathrm{Sn}, \mathrm{Rh}, \mathrm{Ru}, \mathrm{Ce}, \mathrm{Pd}, \mathrm{Au}, \mathrm{Bi}$, Ni entre muitos outros têm sido propostos como co-catalisadores para a platina com o intuito de aumentar sua atividade catalítica e/ou reduzir o envenenamento causado por intermediários formados $[7,8,9,10,11,12,13,14,17,40,41,42]$.

Dentre todos os eletrocatalisadores binários estudados até o momento tem sido mostrado que os eletrocatalisadores $\mathrm{PtSn} / \mathrm{C}$ são mais ativos que os demais eletrocatalisadores binários na oxidação eletroquímica do etanol [7-14]

O co-catalisador de Sn atua em potenciais menos positivos melhorando a atividade eletródica na célula, segundo a literatura este efeito provém da formação de uma liga Pt-Sn ou da formação de $\mathrm{SnO}_{2}$ correspondendo respectivamente a dois efeitos denominados como mecanismo bifuncional e mecanismo eletrônico gerando controvérsias quanto a pertinência da melhora eletródica $[43,44,45]$.

\subsubsection{Mecanismo bifuncional e mecanismo eletrônico}

No mecanismo bifuncional o etanol e os intermediários se adsorvem sobre os sítios de platina enquanto que o segundo metal fornece espécies oxigenadas para oxidar os intermediários fortemente adsorvidos, portanto liberando os sítios de platina para uma nova adsorção do combustível [35,46].

Estas espécies oxigenadas desempenham um papel de oxidantes convertendo $\mathrm{CO}$ à $\mathrm{CO}_{2}$ liberando a superfície do eletrocatalisador. As equações $9,10,11$ e 12 descrevem o processo [47]. 


$$
\begin{aligned}
& \mathrm{Pt}+\mathrm{CO} \rightarrow \mathrm{Pt}-(\mathrm{CO})_{\text {ads }} \\
& \mathrm{M}+\mathrm{H}_{2} \mathrm{O} \rightarrow \mathrm{M}-\mathrm{OH}+\mathrm{e}^{-}+\mathrm{H}^{+} \\
& \mathrm{Pt}+\mathrm{H}_{2} \mathrm{O} \rightarrow \mathrm{Pt}-\mathrm{OH}+\mathrm{e}^{-}+\mathrm{H}^{+} \\
& \mathrm{M}-\mathrm{OH}+\mathrm{Pt}-(\mathrm{CO})_{\text {ads }} \rightarrow \mathrm{Pt}+\mathrm{CO}_{2}+\mathrm{M}+\mathrm{H}^{+}+\mathrm{e}^{-}
\end{aligned}
$$

No mecanismo eletrônico o co-catalisador forma uma liga com a platina e assim contribui para enfraquecer a interação dos intermediários adsorvidos, isto leva a diminuição na força de ligação entre a molécula de $\mathrm{CO}$ e a superfície do eletrocatalisador $[47,48]$. Os parâmetros de rede da platina sofrem alteração com a entrada do co-catalisador, mais especificamente no orbitais da banda "d" o que justifica uma menor força de interação dos intermediários com a platina $[47,49]$.

Um outro efeito encontrado na literatura que justifica o aumento da atividade eletrocatalítica em catalisadores binários e/ou ternários é o processo de-alloying (processo de segregação de determinados átomos em uma liga).

\subsubsection{Processo de-alloying}

Um dos procedimentos que vem sendo estudados em eletrocatalisadores para células a combustível é processo de-alloying [84]. Trata-se de um processo comum de corrosão, no qual o componente mais eletroquimicamente ativo (metal menos nobre) de uma liga é removido por dissolução seletiva [84]. Alguns colaboradores mostram que a oxidação eletroquímica do etanol é favorecida sobre determinados planos cristalográficos da estutura CFC da platina. Segundo o processo de-alloying a remoção de alguns átomos do co-catalisador em ligas de Pt leva a formação de "defeitos" em sua estrutura CFC, que poderiam favorecer uma maior exposição desses planos cristalográficos e, consequentemente, aumentar a eficiência eletródica na oxidação do etanol $[85,86]$. 


\subsection{Carbono e óxidos como suporte}

O uso de eletrocatalisadores por si próprios tem demonstrado eficiências energéticas menores ao longo da história no uso da tecnologia de células a combustível. Pesquisas realizadas em diversos centros internacionais têm levado ao desenvolvimento dos chamados eletrocatalisadores dispersos ou suportados onde os eletrocatalisadores em formas de partículas nanométricas são ancoradas em um suporte adequado [32].

O negro de fumo ou carbono, trata-se de um produto fabricado pela decomposição térmica de hidrocarbonetos. São nanopartículas esféricas de tamanho coloidal. Suas aplicações são encontradas em diversas áreas como na indústria de pneus tintas e plásticos. Entre suas várias propriedades podemos destacar; boa condutividade elétrica, excelente adsorção de luz do infravermelho até o ultravioleta, alta adsorção não polar, baixa gravidade especifica e ser quimicamente inerte [50].

Existem vários tipos de negro de fumo, entre eles, o carbono Vulcan XC 72 que tem sido usado como suporte nos eletrodos em ânodo e cátodo nas células a combustível do tipo PEMFC por apresentarem excelente condutividade em níveis de carga de platina relativamente baixos além de possuir alta área superficial o que contribui para uma boa dispersão dos eletrocatalisadores. Por estas propriedades o carbono Vulcan XC 72 cumpre satisfatoriamente a função de suporte em eletrodos na tecnologia de células a combustível [50].

Uma outra proposta que vem sendo amplamente estudada é o uso de eletrocatalisadores de Pt decorados ou suportados em óxidos como: $\mathrm{TiO}_{2}, \mathrm{SnO}_{2}$, $\mathrm{RuO}_{2}, \mathrm{Sb}_{2} \mathrm{O}_{5}, \mathrm{In}_{2} \mathrm{O}_{3}$ e $\mathrm{CeO}_{2}$, onde estes materiais tem mostrado uma melhora na atividade catalítica por fornecerem espécies oxigenadas (mecanismo bifuncional), maior resistência à corrosão e uma menor diminuição da área real ativa para a eletro-oxidação de etanol em comparação com testes contendo platina suportada em carbono. Dentre todos os materiais relatados acima tem sido dado uma atenção especial ao óxido de índio $\left(\ln _{2} \mathrm{O}_{3}\right)$, este material tem sido amplamente utilizado para reforma de vapor de metanol e de desidrogenação de etanol $[16,17,18,19]$. 


\subsection{Métodos de preparação de catalisadores}

Um dos parâmetros mais importantes no desenvolvimento de eletrocatalisadores é o tamanho das partículas dos metais ancorados no suporte. As reações de oxidação que ocorrem nos eletrodos das células a combustível são heterogêneas e envolvem a adsorção de moléculas eletroativas na superfície dos eletrocatalisadores [51,52].

Muitos são os métodos utilizados na preparação de eletrocatalisadores metálicos suportados em carbono. Spinacé e colabores [52], descrevem alguns métodos como: o método de redução por álcool, o método de precursores poliméricos, o método de Bönnemann e o método de ácido fórmico onde estes métodos estão sendo estudados e/ou desenvolvidos com o intuito de se obter um controle satisfatório do tamanho, da composição e da dispersão das partículas metálicas formadas para as aplicações em células do tipo PEMFC.

\subsubsection{Método de redução por álcool}

O método da redução por álcool foi desenvolvido por Toshima e Yonezawa, para preparar dispersões coloidais de partículas manométricas de tamanho e distribuição bem uniformes. Esta metodologia baseia-se no refluxo de uma solução alcoólica contendo o íon metálico na presença de um agente estabilizante, normalmente um polímero, o que fornece dispersões coloidais homogêneas das nanopartículas metálicas correspondentes. $O$ álcool funciona como solvente e agente redutor, sendo oxidado a aldeídos e cetonas [52]. Conforme a equação 13.

$$
\mathrm{H}_{2} \mathrm{PtCl}_{6}+2 \mathrm{CH}_{3} \mathrm{OH} \rightarrow \mathrm{Pt}^{0}+2 \mathrm{HCHO}+6 \mathrm{HCl}
$$

As principais vantagens do método de redução por álcool são; procedimento muito simples e reprodutível, nanopartículas pequenas e bem distribuídas, dipersões coloidais de nanopartículas com alta atividade catalítica e bastante estáveis, possibilidade de controle do tamanho das nanopoartículas alterando-se as condições de preparação, como a escolha do álcool, a 
temperatura de redução, a quantidade e variedade do agente estabilizante, a concentração do íon metálico e o uso de aditivos [52].

\subsubsection{Método de precursores poliméricos}

O Método de precursores poliméricos, também conhecido como método de Pechini, foi patenteado por Magio Pechini em julho de 1967 [68].

A metodologia consiste na dissolução de um metal em um béquer contendo água deionizada em agitação constante, sob temperaturas que variam de $60^{\circ} \mathrm{C}$ a $70^{\circ} \mathrm{C}$. Em seguida, adicionam-se um ácido e um o poliálcool nas proporções molares corretas. A reação de esterificação ocorre com o aumento da temperatura da solução, para valores entre $85^{\circ} \mathrm{C}$ e $110^{\circ} \mathrm{C}$. Após este procedimento a solução resultante é seca em estufa e depois calcinada para total remoção da água e de materiais orgânicos. Na produção de nanopartículas, a espuma resultante da calcinação, conhecida como "puff", é moída e novamente calcinada a temperaturas mais elevadas. O puff ocorre devido ao aprisionamento dos gases $\mathrm{CO}$ e $\mathrm{CO}_{2}$ durante o processo de calcinação $[68,69]$.

O método de precursores moleculares apresenta boas vantagens como síntese a baixas temperaturas, baixa contaminação e possibilidade de obtenção de pós nanométricos. Suas desvantagens são o alto custo de alguns reagentes e a formação de pós aglomerados [69].

\subsubsection{Método de Bönnemann}

O método de Bönnemann, também conhecido como método coloidal, pode ser aplicado para a obtenção de catalisadores mistos ou sistemas de catalisadores, ternários e quaternários, sobre carvão ativo e carvão ativo grafitizado. Dentre as aplicações esta metodologia destaca-se para obtenção de eletrocatalisadores a base de platina e ligas contendo metais e/ ou óxidos de metais. Em particular, Sn, V, W e Mo e demais elementos de transição, como $\mathrm{Cu}, \mathrm{Fe}, \mathrm{Co}$ e Ni [52].

De maneira mais simples, esta metodologia consiste na preparação de um sistema coloidal em atmosfera inerte, utilizando-se solventes e sais 
desidratados. A principal característica é a dissolução dos sais metálicos em uma solução de tetraidrofurano (THF) onde também se prepara o agente redutor.

A fase final consiste em adicionar a dispersão coloidal vagarosamente à suspensão de pó de carbono (suporte) em THF [52].

A desvantagem principal deste método é o custo, devido ao uso de materiais e ao mantimento de uma atmosfera inerte. Franco e colaboradores prepararam no IPEN/CNEN-SP eletrocatalisadores ternários Pt:Ru:Mo com razões atômicas 1:1:1 e 1:1:0,5 pelo método de Bönnemann. As análises por microscopia eletrônica de transmissão mostraram que, para ambos os eletrocatalisadores, as nanopartículas apresentavam-se bem distribuídas e possuíam tamanhos em torno de $2 \mathrm{~nm}$ [52].

\subsubsection{Método do ácido fórmico}

O método do ácido fórmico [70] foi desenvolvido pelo grupo de eletroquímica do Instituto de Química de São Carlos-USP com a finalidade de preparar eletrocatalisadores de $\mathrm{Pt} / \mathrm{C}$.

Esta metodologia consiste na preparação de eletrocatalisadores via redução química, visando alta atividade catalítica e quantidade reduzida de metal nobre. Inicialmente o carbono Vulcan XC 72 é adicionado a uma solução de ácido fórmico e a mistura é aquecida à $80 \stackrel{\circ}{\circ}$. Posteriormente uma solução contendo os sais de platina e os sais do co-catalisador são adicionados em etapas. Para o controle do andamento da redução, utiliza-se o iodeto de potássio como reagente externo, com a finalidade de indicar a presença de platina em solução apresentando uma coloração vermelha. Após a redução total da platina não se observa mais o tom avermelhado e novas adições da solução contendo os íons metálicos podem ser realizadas. Após a redução total da platina, o catalisador é filtrado, seco e triturado $[52,70]$

Normalmente os eletrocatalisadores utilizados em células a combustível são preparados em nanopartículas metálicas dispersas em um material condutor (suporte) geralmente o carbono Vulcan XC 72 [53] 


\subsubsection{Método de impregnação-redução}

Uma das maneiras mais convencionais de preparação de catalisadores metálicos suportados é a impregnação dos sais metálicos no suporte e sua posterior redução, isso ocorre freqüentemente em fluxo de hidrogênio à alta temperatura [52].

O método de impregnação-redução é frequentemente utilizado na cátalise heterogênea. Ele consiste em ativar o hipoclorito de sódio no suporte de carbono formando grupos de ácido carboxílico superficiais que posteriormente são transformados em sais de amônio após o tratamento com amônia [51]. O sal metálico quando em contato com os grupos amônio substituem sua posição na molécula (sofrem troca) e em seguida o precursor do catalisador é reduzido formando partículas metálicas. Eletrocatalisadores de platina apresentam tamanho de partícula próximos a $2 \mathrm{~nm}$ e boa dispersão sobre o suporte quando utilizados deste método [51].

Uma das limitações desse método é a carga metálica do eletrocatalisador que não excede $10 \%$ de sua massa total sendo um valor muito baixo para a aplicação em células do tipo DAFC [51].

\subsubsection{Método de redução por borohidreto de sódio}

O procedimento de preparação de catalisadores eletroquímicos via redução borohidreto de sódio é uma das variações do método de impregnaçãoredução, além de se poder controlar satisfatoriamente o tamanho, a dispersão e a composição das nanopoartículas, diferentemente do método impregnaçãoredução, pode-se obter também elevadas cargas metálicas de Pt suportadas em carbono [55,56,57].

O borohidreto de sódio $\left(\mathrm{NaBH}_{4}\right)$ é encontrado geralmente na forma de um sólido branco podendo ser um pó ou estar em forma de pelotas. Possui boa solubilidade em metanol $\left(0,13 \mathrm{~g} \mathrm{~mL}^{-1}\right)$, etanol $\left(3,16 \times 10^{-2} \mathrm{~g} \mathrm{~mL}^{-1}\right)$ e em água $(0,54$ $\left.\mathrm{g} \mathrm{mL}^{-1}\right)$. Decompõe-se em etanol e metanol formando boratos. Em água é estável em $\mathrm{pH}$ 14, mas se decompõe em soluções de pH ácido ou neutro [55]

Trata-se de um agente redutor inodoro, bastante utilizado na produção de compostos orgânicos e inorgânicos. Sendo um método de simples execução, 
sua eficácia comprovada na produção de nanopartículas atesta o seu uso neste trabalho. 


\section{MATERIAIS E MÉTODOS}

\subsection{Preparação e caracterização dos eletrocatalisadores}

Os eletrocatalisadores PtSn/C-ITO foram preparados com uma carga metálica de $20 \%$ em massa a partir de sais de Platina (ácido hexacloroplatínico), estanho (cloreto de estanho) e $85 \%$ de suporte de carbono Vulcan XC $72+15 \%$ ITO. Os eletrocatalisadores foram preparados com diferentes composições atômicas binárias 50:50, 70:30 e 90:10, pelo método de redução por borohidreto de sódio.

No método de redução via borohidreto de sódio o suporte de carbono Vulcan XC $72+15 \%$ ITO foram adicionados a uma solução de $25 \mathrm{~mL}$ de água deionizada e $25 \mathrm{~mL}$ de álcool isopropílico junto aos íons metálicos a serem reduzidos. Em seguida, essa mistura ficou em agitação magnética para a total homogeneização por aproximadamente 10 minutos. Com intuito de se obter uma melhor dispersão das partículas metálicas no suporte, esta solução foi levada ao ultrassom por 10 minutos. Posteriormente adicionou-se uma solução aquosa de borohidreto de sódio onde esta solução foi preparada em meio alcalino por hidróxido de sódio 0,01 M para evitar sua decomposição [55]. A mistura final foi constantemente agitada por 30 minutos em temperatura ambiente e ao final do processo a suspensão foi filtrada e o produto resultante lavado com 4 litros de água para remoção de impurezas. Finalmente o material foi seco a $70^{\circ} \mathrm{C}$ em uma estufa por um período de 2 horas [28,29,58,59].

\subsubsection{Preparação do eletrodo de trabalho pela técnica de camada fina porosa}

A técnica utilizada na preparação dos eletrodos foi a de camada finaporosa $[60,61]$.

Primeiramente, $20 \mathrm{mg}$ do eletrocatalisador foram pesados e adicionados a um béquer com $50 \mathrm{~mL}$ de água deionizada e 3 gotas de uma dispersão $6 \%$ de Teflon. Em seguida a mistura foi levada a um sistema de ultrassom por 10 minutos. Após este processo efetuou-se a filtração por um sistema à vácuo. 
Como último passo o filtro com o eletrocalisador filtrado foi alocado em uma placa de Petri na qual a amostra foi retirada por uma espátula e fixada sobre a cavidade do eletrodo de grafite para a efetivação das análises eletroquímicas.

\subsection{Caracterização eletroquímica dos eletrocatalisadores}

As técnicas utilizadas foram a voltametria cíclica e cronoamperometria. Com a técnica da voltametria cíclica foi possível obter o perfil voltamétrico das diferentes formulações preparadas. Por intermédio da técnica cronoamperametria observou-se o decaimento da corrente em função do tempo de operação, nestes estudos considerou-se um potencial fixo, onde o mesmo é fixado com o auxílio de um potenciostato.

Os estudos eletroquímicos em voltametria cíclica e cronoamperometria para o meio ácido foram realizados no potenciostato/galvanostato MQPGMicroquímica em soluções com concentrações $0,5 \mathrm{~mol} \mathrm{~L}^{-1}$ de $\mathrm{H}_{2} \mathrm{SO}_{4}$ na presença de $1,0 \mathrm{~mol} \mathrm{~L}^{-1}$ de etanol. Para obtenção dos resultados de voltametria cíclica e cronoamperometria foram utilizadas células eletroquímicas convencionais de um compartimento, onde o eletrodo de trabalho utilizado foi o de camada fina porosa, o contra eletrodo uma placa de platina e como eletrodo de referência, o reversível de hidrogênio. As voltametrias cíclicas foram obtidas na faixa de potencial de $0,05 \mathrm{~V}$ a $0,8 \mathrm{~V}$ a uma velocidade de $10 \mathrm{mV} \mathrm{s}^{-1}$. Para os estudos com a técnica de cronoamperometria fixou-se o potencial em $0,5 \mathrm{~V}$ por 30 minutos, com 0 objetivo de verificar o decaimento da corrente em função do tempo, além da estabilidade do eletrocatalisador na reação estudada [31]. Durante todas as análises eletroquímicas a solução foi saturada com $\mathrm{N}_{2 \text { (gasoso). }}$

Já os estudos eletroquímicos em voltametria cíclica e cronoamperometria para o meio alcalino foram realizados no potenciostato/galvanostato Autolab PGSTAT 30 em uma solução $1.0 \mathrm{~mol} \mathrm{~L}^{-1}$ de $\mathrm{KOH}$ na presença de $1,0 \mathrm{~mol} \mathrm{~L}^{-1} \mathrm{de}$ etanol. Para obtenção dos resultados de voltametria cíclica e cronoamperometria foram utilizadas células eletroquímicas convencionais de um compartimento, onde o eletrodo de trabalho utilizado foi o de camada fina porosa, o contra eletrodo foi uma placa de platina e como eletrodo de referência o eletrodo de $\mathrm{Ag} / \mathrm{AgCl}\left(3.0 \mathrm{~mol} \mathrm{~L}^{-1} \mathrm{KCl}\right)$. Os voltamogramas cíclicos foram obtidos em um potencial de $-0,85 \mathrm{~V}$ a $0,2 \mathrm{~V}$ a uma velocidade de $10 \mathrm{mV} \mathrm{s}^{-1}$. Para os estudos 
com a técnica de cronoamperometria fixou-se o potencial em $-0,4 \mathrm{~V}$ por 30 minutos. Durante todos os experimentos a solução foi saturada com $\mathrm{N}_{2 \text { (gasoso). }}$

\subsection{Caracterização físico-química dos eletrocatalisadores}

Os eletrocatalisadores $\mathrm{PtSn} / \mathrm{C}$-ITO preparados, foram caracterizados por difração de raios $X$ (DRX), microscopia eletrônica de transmissão (MET) e energia dispersiva de fluorescência de raios $X$ (EDX).

\subsubsection{Técnica de difração de raios $X$ (DRX)}

As medições de difração de raios $\mathrm{x}$ foram realizadas pelo equipamento Rigaku modelo Miniflex II com fonte de radiação de $\operatorname{CuK}_{\alpha}(\lambda=1,54056 \AA$ ), com intervalo de medida em $2 \theta$ de $20^{\circ}$ a $90^{\circ}$, incrementos de $0,05^{\circ}$ e velocidade de varredura de $2^{\circ} \mathrm{min}^{-1}$. Para estes experimentos uma pequena quantidade do eletrocatalisador foi compactada em um suporte de vidro.

A estimativa do tamanho dos cristalitos foi obtida com o auxílio da equação de Scherrer [62] equação 14 . Foi utilizado o pico de reflexão correspondente ao plano (220) da estrutura cúbica de face centrada (cfc) da platina por encontrar-se isolado e ser bem definido, não apresentando contribuições significativas dos demais picos registrados, principalmente do pico de difração largo referente ao suporte de carbono [63].

$$
d=\frac{k \cdot \lambda}{\beta \cos (\theta)}
$$

$\mathrm{Na}$ equação de Scherrer d é o tamanho médio do cristalito dado em angstroms, $k$ é o fator forma (para cristalitos esféricos o valor utilizado é de 0,9 ), $\lambda$ é o comprimento de onda da radiação $(1,5406 \AA$ ) e $\beta$ é a largura do pico de reflexão máxima à meia altura.

O parâmetro de rede é outra informação que se pode obter através da técnica de difração de raios x. Utilizou-se dados da posição $\theta_{\max }$ na reflexão (220) de acordo com a equação 15. 


$$
d=\frac{\sqrt{2} \cdot \lambda}{\operatorname{Sen}(\theta)}
$$

Onde $\lambda$ é o comprimento da onda da radiação (1,54056 Å), $\theta$ é ângulo de difração (ângulo de Bragg) para o ponto de altura máxima do pico analisado (220). A ocorrência de alguma variação nos ângulos de Bragg confirma a inserção de um segundo elemento na estrutura da platina, sendo proporcional ao tamanho do raio atômico desse elemento inserido [66].

A técnica de DRX é geralmente utilizada para cristais de dimensões entre $2 \mathrm{~nm}$ e $50 \mathrm{~nm}$. Uma limitação desta técnica está relacionada ao tamanho da medição dos cristalitos no qual valores acima de $50 \mathrm{~nm}$ apresentam picos de difração muito estreitos dificultando a avaliação, enquanto valores menores que $3 \mathrm{~nm}$ apresentam picos muito achatados, onde a largura dos reflexos aumenta com a diminuição do tamanho da partícula, o que torna o reconhecimento dos picos de difração difíceis [64,65].

Uma segunda limitação consiste no fato de que somente fases cristalinas podem ser registradas, ou seja, fases amorfas existentes permanecem não detectadas no DRX. Um complemento aos estudos com a técnica de difração de raios $X$ pode ser obtido através da técnica de microscopia de transmissão eletrônica (MET).

\subsubsection{Técnica de microscopia eletrônica de transmissão (MET)}

A Microscopia Eletrônica de Transmissão (MET) permite obter informações com respeito ao tamanho e a distribuição de nanopartículas no suporte, consequentemente é possível avaliar se a rota de síntese proposta é efetiva ou não para a preparação dos eletrocatalisadores [30]. Foi utilizado um microscópio eletrônico de transmissão JEOL modelo JEM-2100 (200kV). Para a análise no equipamento foi preparada uma suspensão de cada catalisador em 2-propanol homogeneizada por sistema de ultrassom. Em seguida foi depositada uma alíquota da amostra preparada em um porta amostra de cobre $(0,3 \mathrm{~cm}$ de diâmetro) com um filme de carbono. Para cada amostra foram obtidas oito 
micrografias, com isto a coleção de dados foi suficiente para a construção dos histogramas que representam a distribuição do tamanho das nanopartículas. Foi efetuada a medida de 150 partículas em cada amostra para a construção dos histogramas e o cálculo do tamanho médio entre elas.

\subsubsection{Software Image $\mathbf{J}$}

As micrografias obtidas pelo microscópio de transmissão JEOL modelo JEM-2100 (200 kV) geram imagens contendo as partículas do eletrocatalisadores junto ao suporte. Estas imagens foram analisadas com o auxílio do software Image J 1.50i [54] onde foi possível fazer uma estimativa do tamanho das partículas e da área dos eletrocatalisadores preparados.

\subsubsection{Técnica de espectroscopia de energia dispersiva de raios $x$ (EDX)}

Para os estudos com a técnica de EDX utilizou-se do microscópio eletrônico de varredura Philips, modelo XL30 com feixe de elétrons de $20 \mathrm{keV}$ equipado com microanalisador EDAX modelo DX-4 onde uma pequena quantidade dos eletrocatalisadores era colocada em um porta amostra de alumínio com o auxílio de uma fita dupla face [73].

\subsection{Produção do conjunto membrana-eletrodos (MEA)}

Para a preparação dos eletrodos que foram empregados nos estudos em células a combustível utilizou-se a membrana Nafion 117 (DuPontTM) como eletrólito, enquanto que a camada difusora foi o papel de carbono teflonado ECTP1-060T (30\% teflon) importado pela empresa ElectroChem. A camada catalítica do cátodo foi preparada utilizando o catalisador comercial Pt/C E-TEK (20\% de Pt em massa, lote: C0740621) com 1 mg de Pt cm ${ }^{-2}$ e 30\% de Nafion®, já para a preparação da camada catalítica do ânodo foi utilizado $1 \mathrm{mgPt} \mathrm{cm}^{-2}$ dos eletrocatalisadores preparados e 30\% de Nafion (dispersão 5\% DE520 da DuPontTM) [31]. As camadas catalíticas preparadas foram aplicadas manualmente sobre o papel de carbono pela técnica de pintura por pincel até a total transferência da carga catalítica. Para a formação do MEA os dois eletrodos 
preparados foram prensados junto a membrana de Nafion, a $125{ }^{\circ} \mathrm{C}$ por 1,5 minutos a uma pressão de 5 toneladas (ou $225 \mathrm{kgf} \mathrm{cm}^{-2}$ ) [31].

\subsubsection{Experimentos em célula unitária}

Os experimentos em células para as medidas de polarização foram realizados por uma célula unitária ElectroCell com placas de grafite tipo serpentina com uma área geométrica interna ativa de $5 \mathrm{~cm}^{2}$ que acomodou 0 MEA, com isto houve distribuição homogênea do combustível por todo o eletrodo. Após a montagem da célula com suas devidas conexões, manteve-se o gás oxigênio umidificado por uma garrafa umidificadora controlada a uma temperatura de $85^{\circ} \mathrm{C}$.

A temperatura da célula foi fixada a $90^{\circ} \mathrm{C}$. No meio ácido o ânodo foi alimentado por um fluxo de $1 \mathrm{~mL} \mathrm{~min}{ }^{-1}$ de etanol em uma concentração de $2 \mathrm{~mol}$ $\mathrm{L}^{-1}$. O cátodo foi mantido sob fluxo de oxigênio de $500 \mathrm{~mL} \mathrm{~min}^{-1}$ pressurizado à 2 bar.

No meio alcalino a membrana polimérica Náfion foi submetida à uma solução de $\mathrm{KOH} 6 \mathrm{~mol} \mathrm{~L}^{-1}$ durante 24 horas antes de se confeccionar o MEA. O ânodo foi alimentado por um fluxo de $1 \mathrm{~mL} \mathrm{~min}^{-1}$ de uma solução $2,0 \mathrm{~mol} \mathrm{~L}^{-1}$ de $\mathrm{KOH}$ na presença de $2,0 \mathrm{~mol} \mathrm{~L}^{-1}$ de etanol. $\mathrm{O}$ cátodo foi mantido sob fluxo de oxigênio de $150 \mathrm{~mL} \mathrm{~min}^{-1}$. Os experimentos em célula unitária foram conduzidos em um painel de testes projetados pela empresa Electrocell.

\subsubsection{Curvas de polarização}

A avaliação do desempenho de uma célula a combustível se faz, geralmente, pelo estudo de sua curva de polarização onde obteve-se a densidade de potência pela relação do potencial da célula com sua respectiva densidade de corrente [67].

As curvas de polarização foram obtidas com o auxílio do equipamento potenciostato/galvanostato Autolab PGSTAT 30 diretamente acoplado a célula unitária do painel de testes projetado pela empresa Electrocell. 


\section{RESULTADOS E DISCUSSÃO}

\subsection{Espectroscopia de energia dispersiva de raios $\mathrm{x}$ (EDX)}

\subsubsection{Composição atômica nominal e experimental (EDX)}

Nesta seção, são apresentados os resultados da composição atômica e as imagens das suas respectivas regiões de varredura para os eletrocatalisadores Pt/C, Pt/C-ITO, PtSn/C 70:30, PtSn/C-ITO 50:50, PtSn/C-ITO 70:30 e PtSn/C-ITO 90:10 sintetizados pelo método de redução via borohidreto de sódio. A TAB. 2 apresenta os resultados da razão atômica obtidas por EDX.

TABELA 2. Composição atômica nominal e experimental, obtida pela técnica EDX, para os eletrocatalisadores Pt/C, Pt/C-ITO, PtSn/C 70:30, PtSn/C-ITO 50:50, PtSn/C-ITO 70:30 e PtSn/C-ITO 90:10 sintetizados pelo método de redução via borohidreto de sódio.

\begin{tabular}{|l|c|c|c|c|}
\hline Eletrocatalisador & $\begin{array}{c}\text { Composição } \\
\text { experimental } \\
\text { de Pt }\end{array}$ & $\begin{array}{c}\text { Composição } \\
\text { experimental } \\
\text { de Sn }\end{array}$ & $\begin{array}{c}\text { Composição } \\
\text { nominal de } \\
\text { Pt }\end{array}$ & $\begin{array}{c}\text { Composição } \\
\text { nominal de } \\
\text { Sn }\end{array}$ \\
\hline Pt/C & 100 & 0 & 100 & 0 \\
\hline Pt/C-ITO & 100 & 0 & 100 & 0 \\
\hline PtSn/C 70:30 & 75,24 & 24,76 & 70 & 30 \\
\hline PtSn/C-ITO 50:50 & 59,30 & 40,70 & 50 & 50 \\
\hline PtSn/C-ITO 70:30 & 72,61 & 27,39 & 70 & 30 \\
\hline PtSn/C-ITO 90:10 & 88,90 & 11,10 & 90 & 10 \\
\hline
\end{tabular}




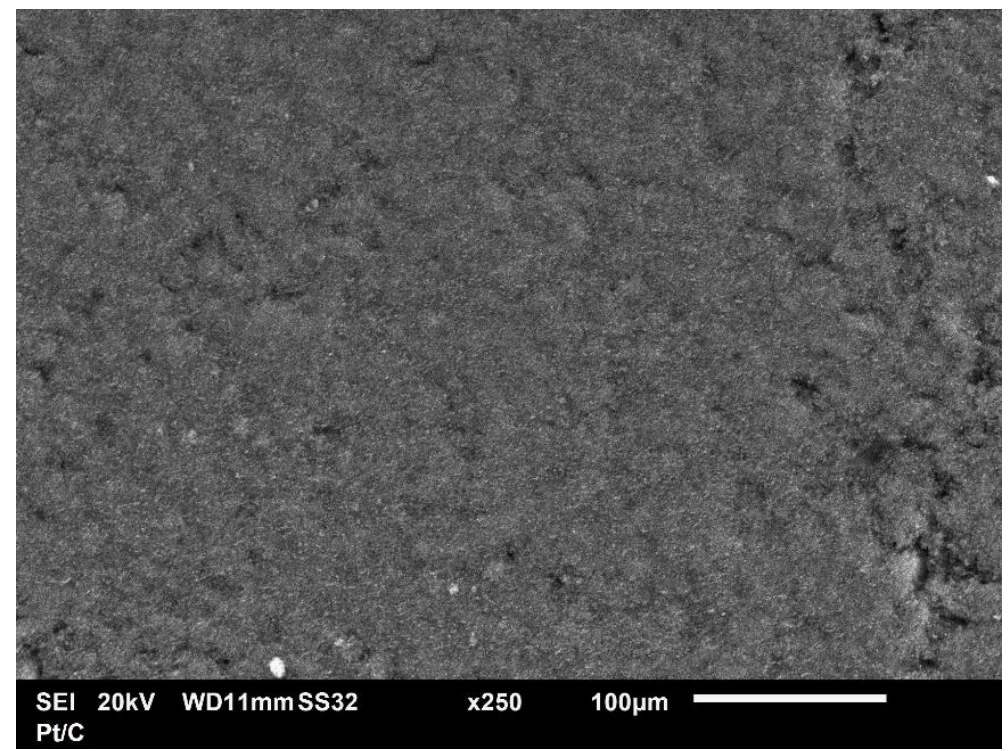

Figura 5. Imagem obtida por microscópio de varredura para o eletrocatalisador $\mathrm{Pt} / \mathrm{C}$.

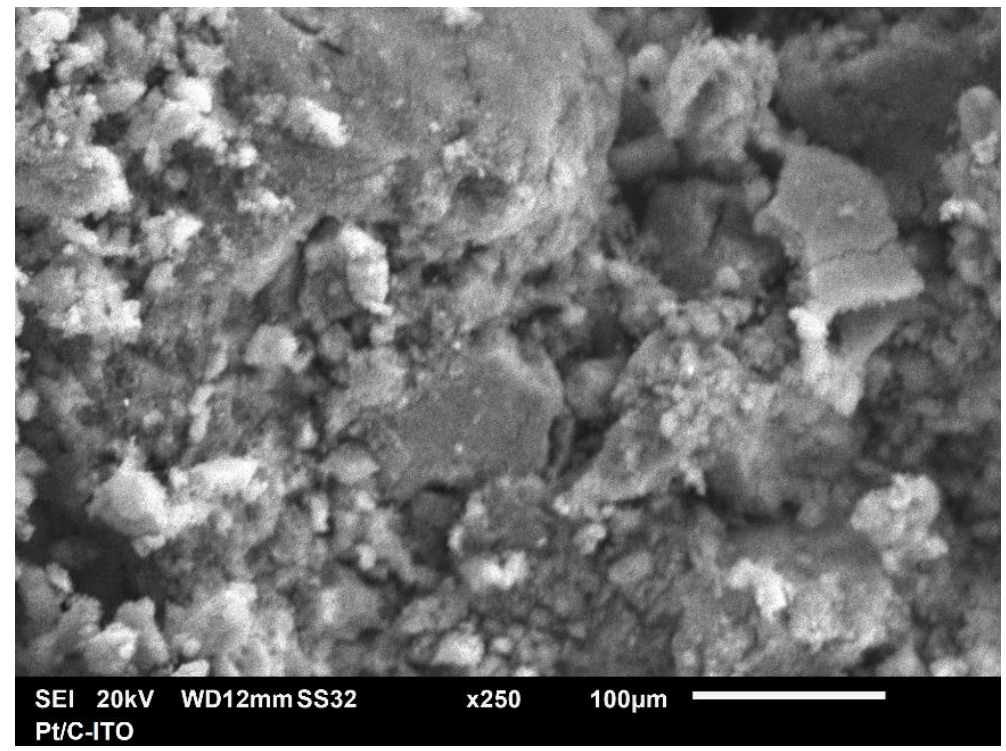

Figura 6. Imagem obtida por microscópio de varredura para o eletrocatalisador Pt/C-ITO. 


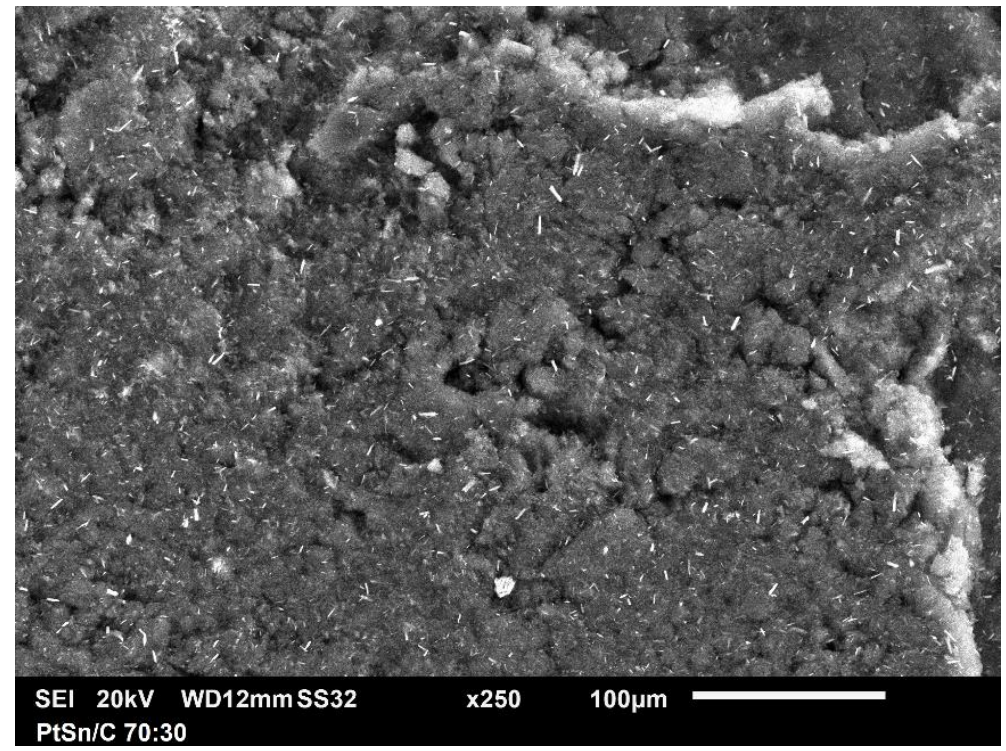

Figura 7. Imagem obtida por microscópio de varredura para o eletrocatalisador PtSn/C 70:30.

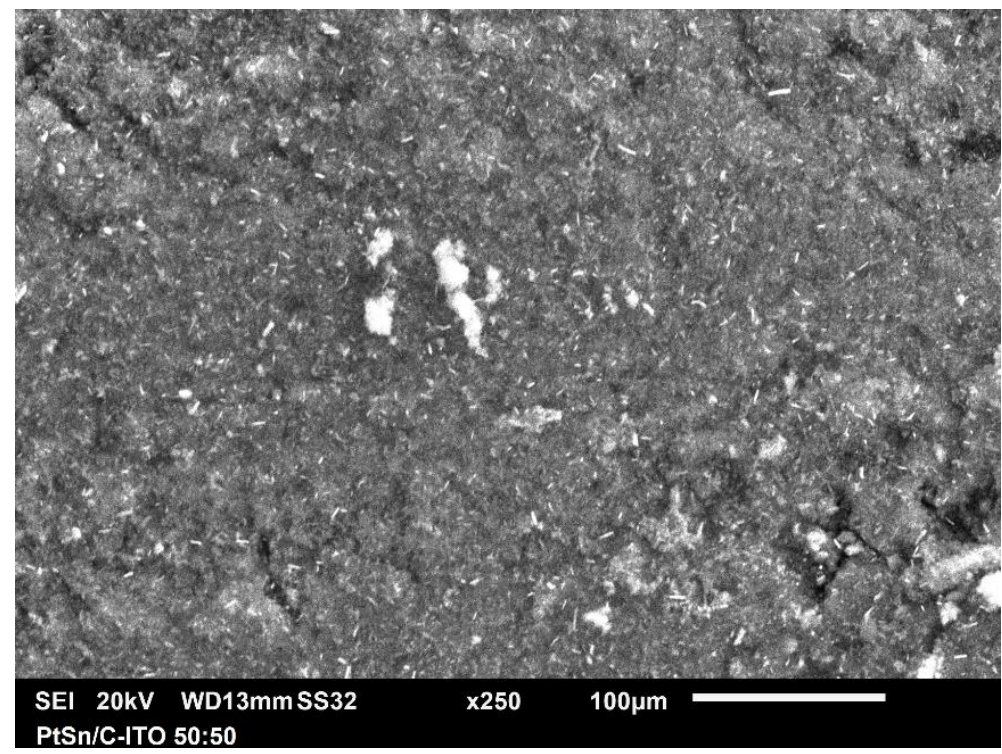

Figura 8. Imagem obtida por microscópio de varredura para o eletrocatalisador PtSn/C-ITO 50:50. 


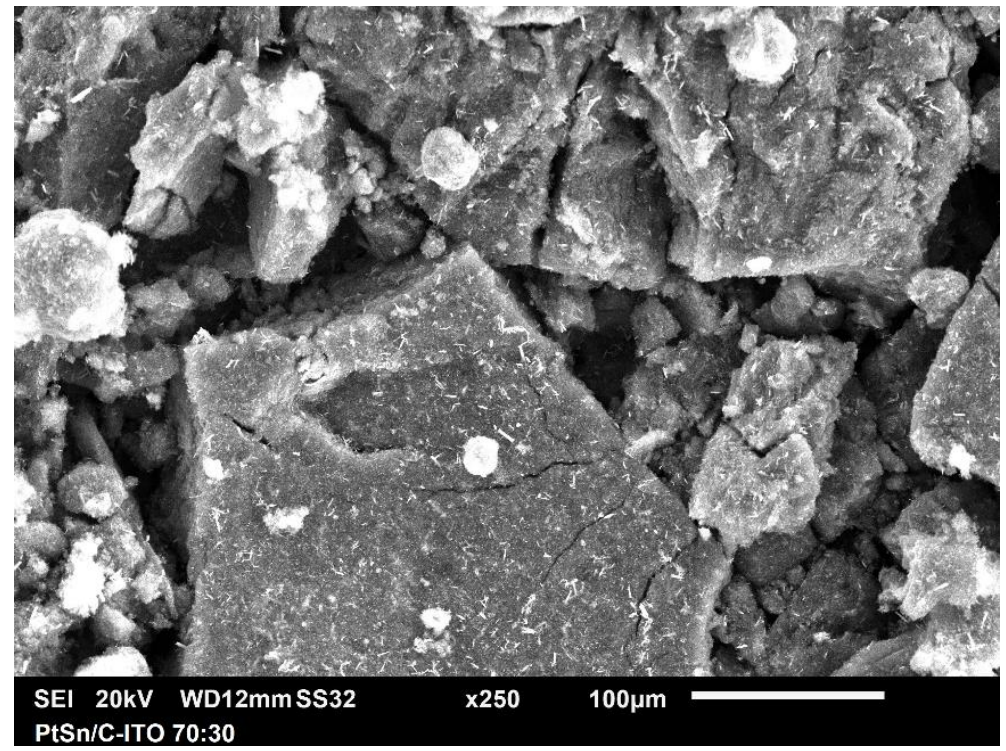

Figura 9. Imagem obtida por microscópio de varredura para o eletrocatalisador PtSn/C-ITO 70:30.

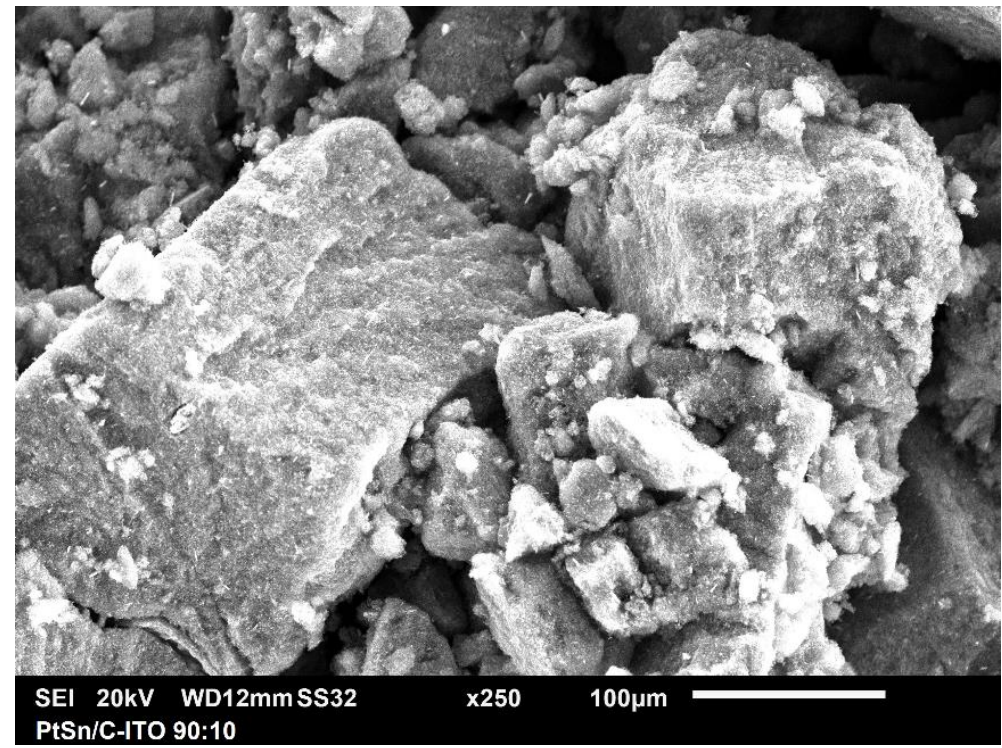

Figura 10. Imagem obtida por microscópio de varredura para 0 eletrocatalisador PtSn/C-ITO 90:10.

As análises por EDX mostraram que as razões atômicas experimentais são similares às composições nominais de partida, exceto o catalisador de PtSn/C-ITO 50:50 que apresentou uma composição experimental de aproximadamente 60:40. 


\subsection{Análise de difração por raios-X (DRX)}

Na FIG.11 são apresentados os difratogramas dos eletrocatalisadores $\mathrm{Pt} / \mathrm{C}, \mathrm{Pt} / \mathrm{C}-$ ITO, PtSn/C 70:30, PtSn/C-ITO 50:50, PtSn/C-ITO 70:30 e PtSn/CITO 90:10.

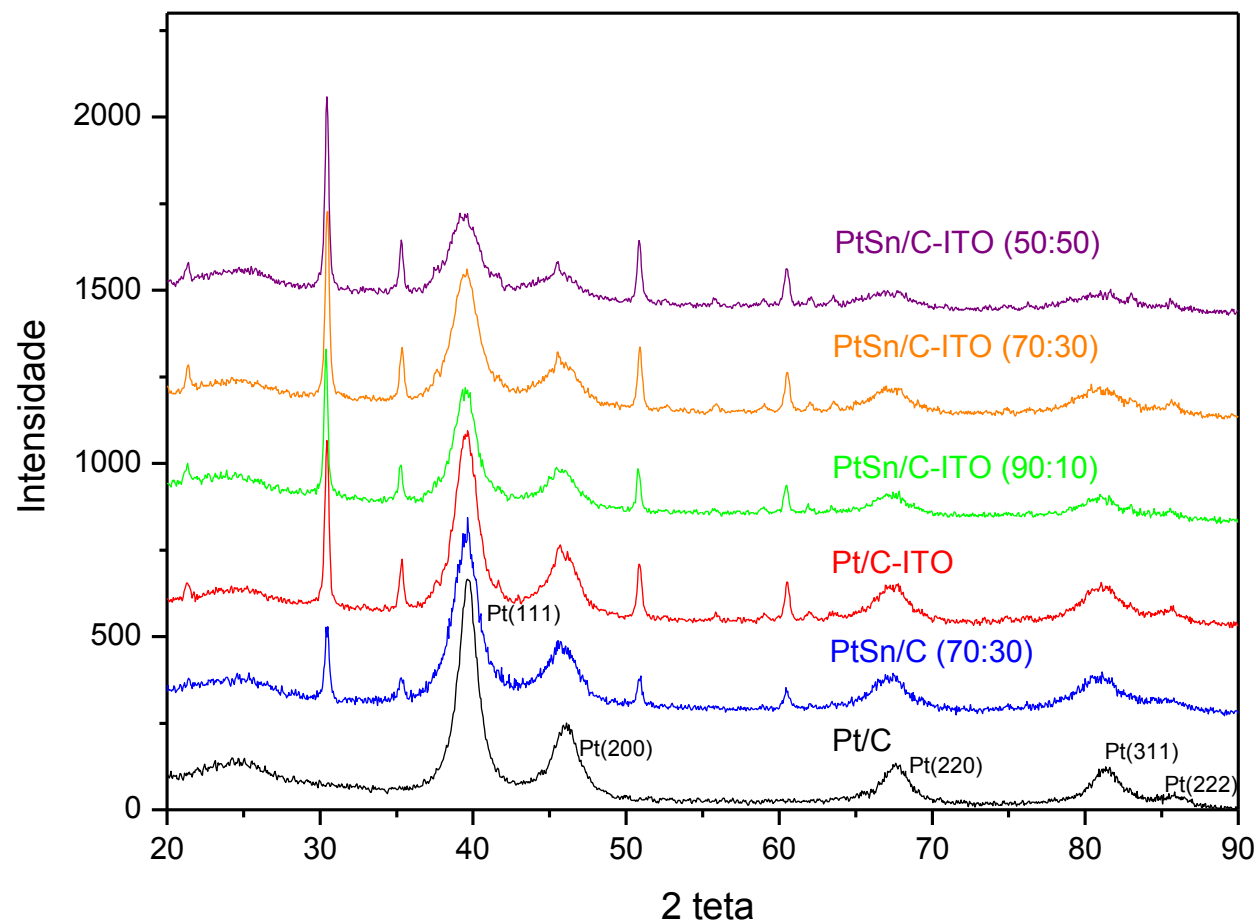

Figura 11. Difratogramas de raios- $x$ dos eletrocatalisadores $\mathrm{Pt} / \mathrm{C}, \mathrm{Pt} / \mathrm{C}-\mathrm{ITO}$, PtSn/C 70:30, PtSn/C-ITO 50:50, PtSn/C-ITO 70:30 e PtSn/C-ITO 90:10.

Em todos os catalisadores é perceptível o pico de difração nas proximidades de $2 \theta=25^{\circ}$ referente ao suporte de carbono Vulcan XC 72 e os picos que aparecem em aproximadamente $2 \theta=40^{\circ}, 46^{\circ}, 67^{\circ}, 80^{\circ}$ e $87^{\circ}$ são associados aos planos (111), (200), (220), (311) e (222) característicos da estrutura cúbica de face centrada da platina. Os picos nas regiões $2 \theta=31^{\circ}, 36^{\circ}$, $51^{\circ}$ e $60^{\circ}$ são perceptíveis nos eletrocatalisadores que contém ITO e correspondem respectivamente aos planos (222), (400), (440), (622) do $\ln _{2} \mathrm{O}_{3}$ que possui estrutura cúbica, estes dados encontrados estão de acordo com os resultados de outros pesquisadores [16,74]. 
A Literatura também indica a incorporação do Sn à Pt, característica que pode ser observada através do deslocamento para menores valores de $2 \theta$ nas posições $40^{\circ}$ e $67^{\circ}$ quando comparado com os picos da estrutura de face centrada encontrados na varredura de difração do eletrocatalisador de Pt/C [71, 73]

Ottoni e colaboradores associam os picos de difração que aparecem nas proximidades de $2 \theta=31^{\circ}, 36^{\circ}, 52^{\circ} \mathrm{E} 62^{\circ}$ a presença dos óxidos de estanho e índio (ITO) [72], fato que leva a crer que tanto o $\mathrm{SnO}_{2}$ quanto o $\ln _{2} \mathrm{O}_{3}$ aparecem nas mesmas regiões do difratograma.

No intervalo da região de $2 \theta=57^{\circ}$ à $2 \theta=64^{\circ}$ é possível visualizar pequenos picos. Ottoni e colaboradores estudaram composições com até $50 \%$ de ITO onde esta região apresentou picos mais intensos a medida que a concentração de ITO aumentava [72]. O eletrocatalisador PtSn/C 70:30 não apresentou estes pequenos picos e, portanto, é possível inferir que esta região nos catalisadores com ITO pode ser atribuída provavelmente aos óxidos de índio.

Os parâmetros de rede para os eletrocatalisadores Pt/C, Pt/C-ITO, $\mathrm{PtSn} / \mathrm{C}$ 70:30, PtSn/C-ITO 50:50, PtSn/C-ITO 70:30 e PtSn/C-ITO 90:10 foram calculados utilizando o pico máximo associado ao plano (220), e são apresentados na TAB 3.

TABELA 3. Parâmetro de rede, para os eletrocatalisadores Pt/C, Pt/C-ITO, $\mathrm{PtSn} / \mathrm{C}$ 70:30, PtSn/C-ITO 50:50, PtSn/C-ITO 70:30 e PtSn/C-ITO 90:10.

\begin{tabular}{|l|c|c|}
\hline \multirow{2}{*}{ Eletrocatalisador } & \multicolumn{2}{|c|}{ DRX } \\
\cline { 2 - 3 } & $\begin{array}{c}\text { Posição do } \\
\text { Pico (graus) }\end{array}$ & $\begin{array}{c}\text { Parâmetro } \\
\text { de rede (nm) }\end{array}$ \\
\hline Pt/C & 67,6 & 0,3917 \\
\hline Pt/C-ITO & 67,45 & 0,3924 \\
\hline PtSn/C 70:30 & 67,45 & 0,3924 \\
\hline PtSn/C-ITO 50:50 & 66,85 & 0,3955 \\
\hline PtSn/C-ITO 70:30 & 67,35 & 0,3929 \\
\hline PtSn/C-ITO 90:10 & 67,6 & 0,3917 \\
\hline
\end{tabular}


O parâmetro de rede dos eletrocatalisadores $\mathrm{Pt} / \mathrm{C}, \mathrm{Pt} / \mathrm{C}-\mathrm{ITO}, \mathrm{PtSn} / \mathrm{C}$ 70:30, PtSn/C-ITO 50:50, PtSn/C-ITO 70:30 e PtSn/C-ITO 90:10 foram respectivamente $0,3917 \mathrm{~nm}, 0,3924 \mathrm{~nm}, 0,3924 \mathrm{~nm}$ e $0,3955 \mathrm{~nm}, 0,3929 \mathrm{~nm}$ e $0,3917 \mathrm{~nm}$. Os cálculos aproximados destes valores indicaram que houve a incorporação do Sn na rede cristalina da platina e conforme a quantidade de Sn foi aumentando, a expansão da rede cristalina da $\mathrm{Pt}$, também foi crescendo, provavelmente pela maior disponibilidade de Sn durante a preparação do eletrocatalisador. Dados que coincidem com a literatura no que se refere ao aumento do parâmetro de rede da Pt à medida que a quantidade de Sn também aumenta $[75,76,77,78]$

A TAB. 4 mostra a estimativa do tamanho de cristalitos calculados pela equação de Scherrer [62].

TABELA 4. Estimativa de tamanho de cristalito calculados pela equação de Scherrer, para os eletrocatalisadores Pt/C, Pt/C-ITO, PtSn/C 70:30, PtSn/C-ITO 50:50, PtSn/C-ITO 70:30 e PtSn/C-ITO 90:10

\begin{tabular}{|l|c|}
\hline & \multicolumn{1}{|c|}{ DRX } \\
\cline { 2 - 2 } Eletrocatalisador & $\begin{array}{c}\text { Estimativa de } \\
\text { tamanho de } \\
\text { cristalito }(\mathbf{n m})\end{array}$ \\
\hline Pt/C & 4 \\
\hline Pt/C-ITO & 4 \\
\hline PtSn/C 70:30 & 3 \\
\hline PtSn/C-ITO 50:50 & 3 \\
\hline PtSn/C-ITO 70:30 & 3 \\
\hline PtSn/C-ITO 90:10 & 4 \\
\hline
\end{tabular}

Os tamanhos médios de cristalito, obtidos pela equação de Scherrer [62], estão na faixa de 3,0 a $4,0 \mathrm{~nm}$ o que indica que o método de redução via borohidreto de sódio foi eficaz para a síntese dos eletrocatalisadores em estudo para a eletro-oxidação do etanol. 


\subsection{Microscopia eletrônica de transmissão (MET)}

A morfologia, o diâmetro médio e a distribuição de tamanho das partículas da superfície de todos os catalisadores foram obtidas por meio da técnica de microscopia eletrônica de transmissão. Os histogramas foram construídos por uma contabilização digital de 150 nanopartículas em diferentes regiões das 8 micrografias para cada amostra.

Nas figuras 12,13,14,15,16 e 17 são apresentados os histogramas e as micrografias com os tamanhos médios das partículas e suas respectivas distribuições para os eletrocatalisadores Pt/C, Pt/C-ITO, PtSn/C 70:30, PtSn/C-ITO 50:50, PtSn/C-ITO 70:30 e PtSn/C-ITO 90:10.

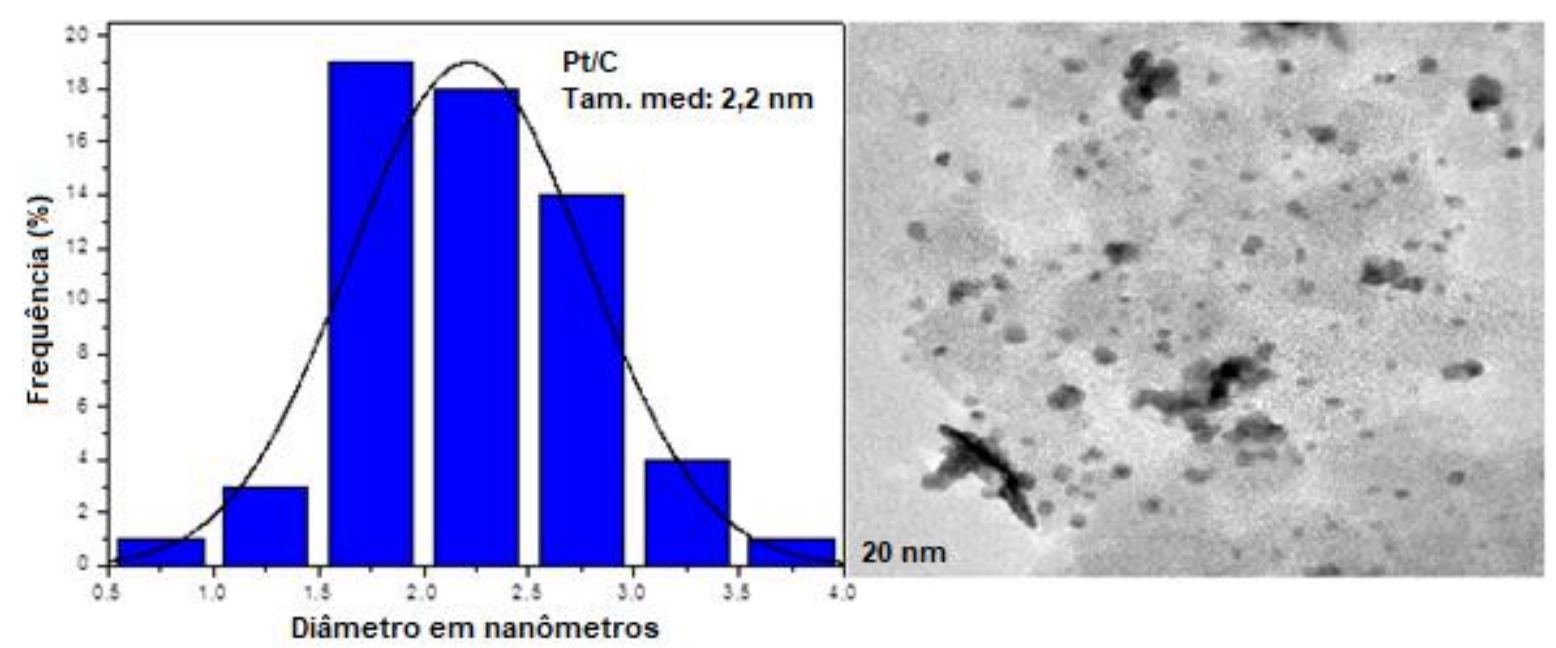

Figura 12. Histograma da distribuição dos tamanhos das partículas do eletrocatalisador Pt/C e micrografia obtida por MET. 


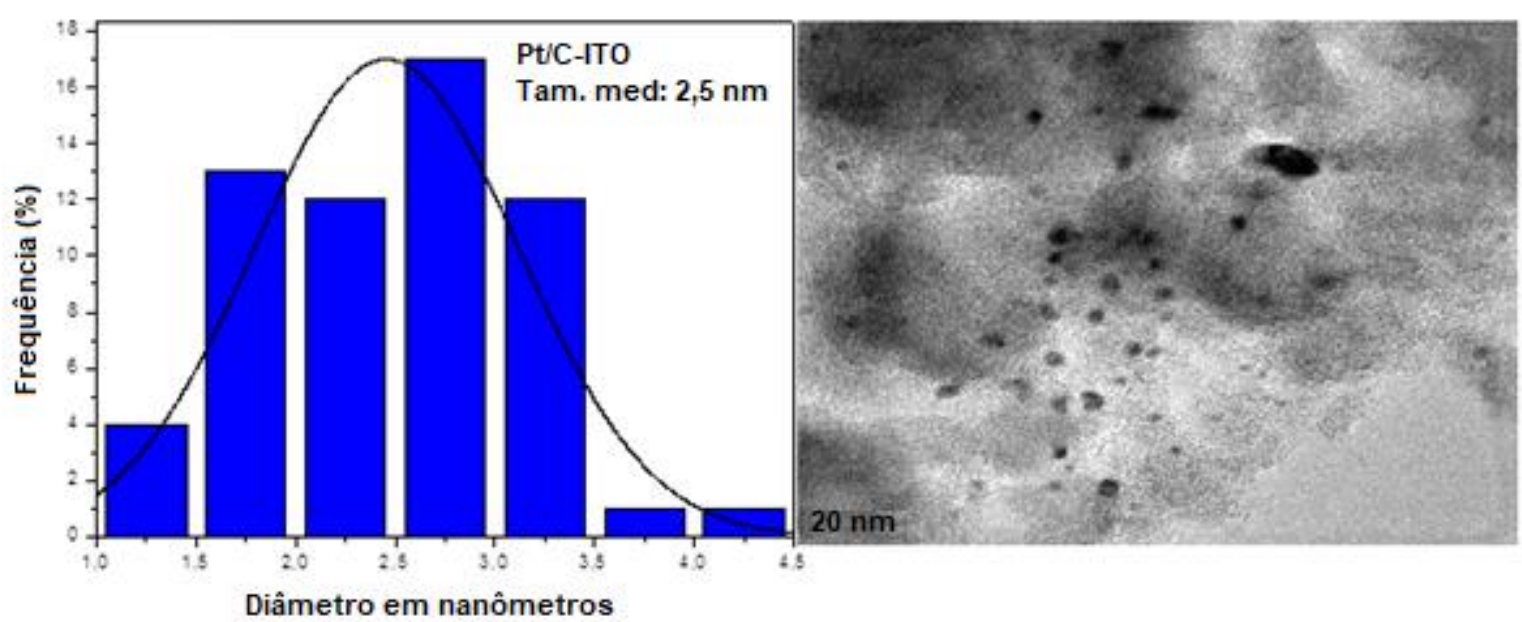

Figura 13. Histograma da distribuição dos tamanhos das partículas do eletrocatalisador Pt/C-ITO e micrografia obtida por MET.

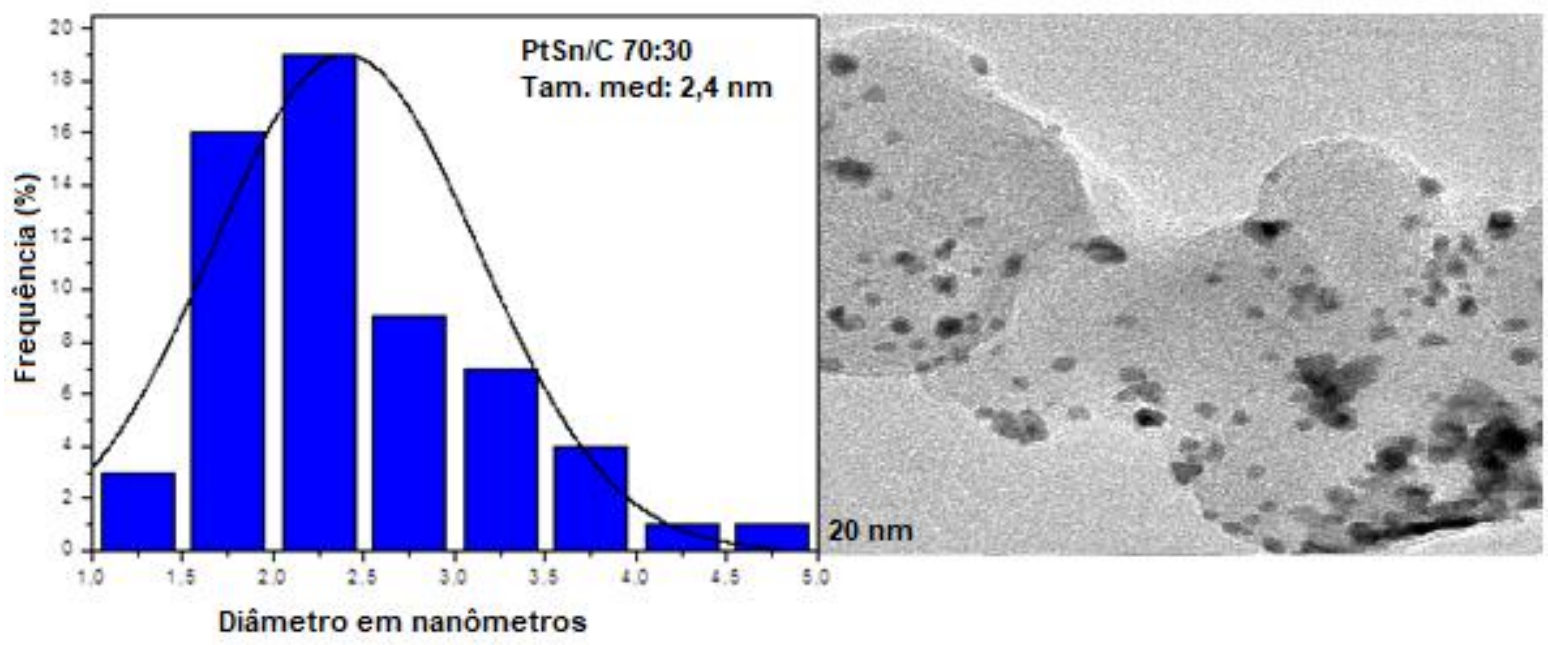

Figura 14. Histograma da distribuição dos tamanhos das partículas do eletrocatalisador PtSn/C 70:30 e micrografia obtida por MET. 


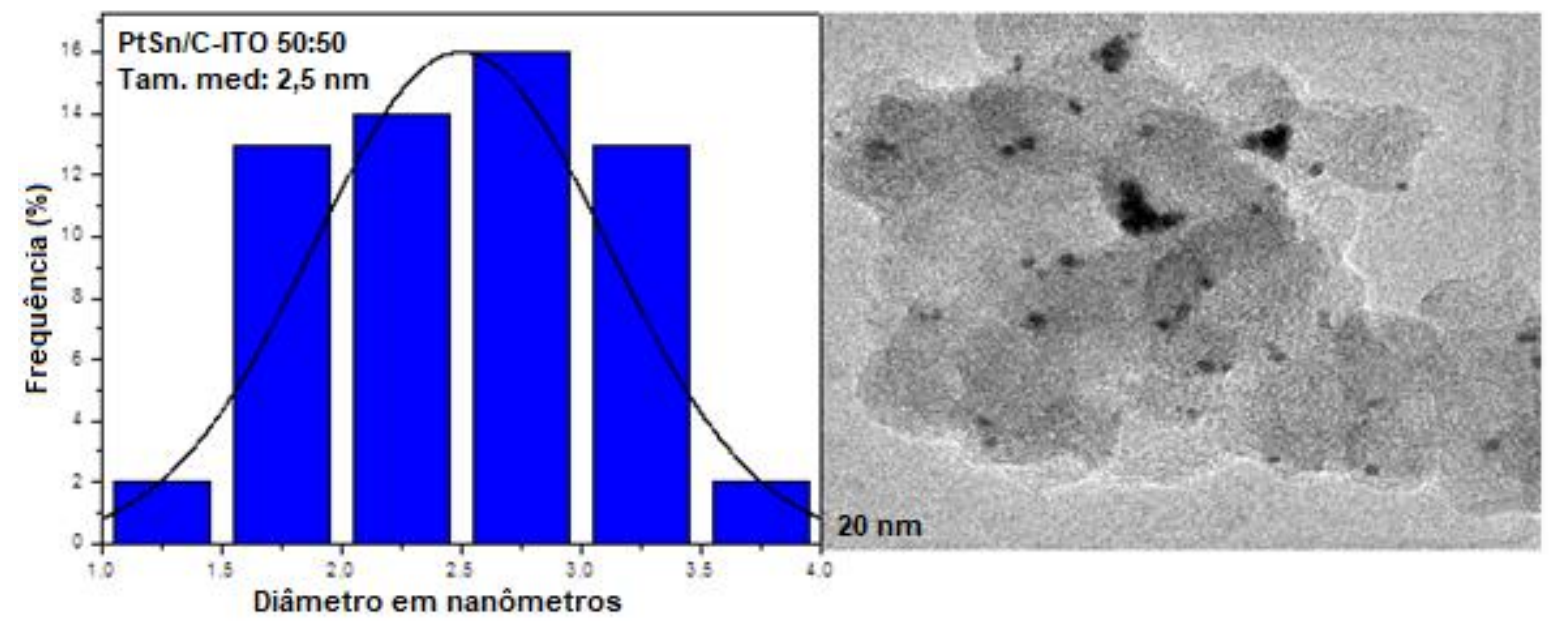

Figura 15. Histograma da distribuição dos tamanhos das partículas do eletrocatalisador PtSn/C-ITO 50:50 e micrografia obtida por MET.

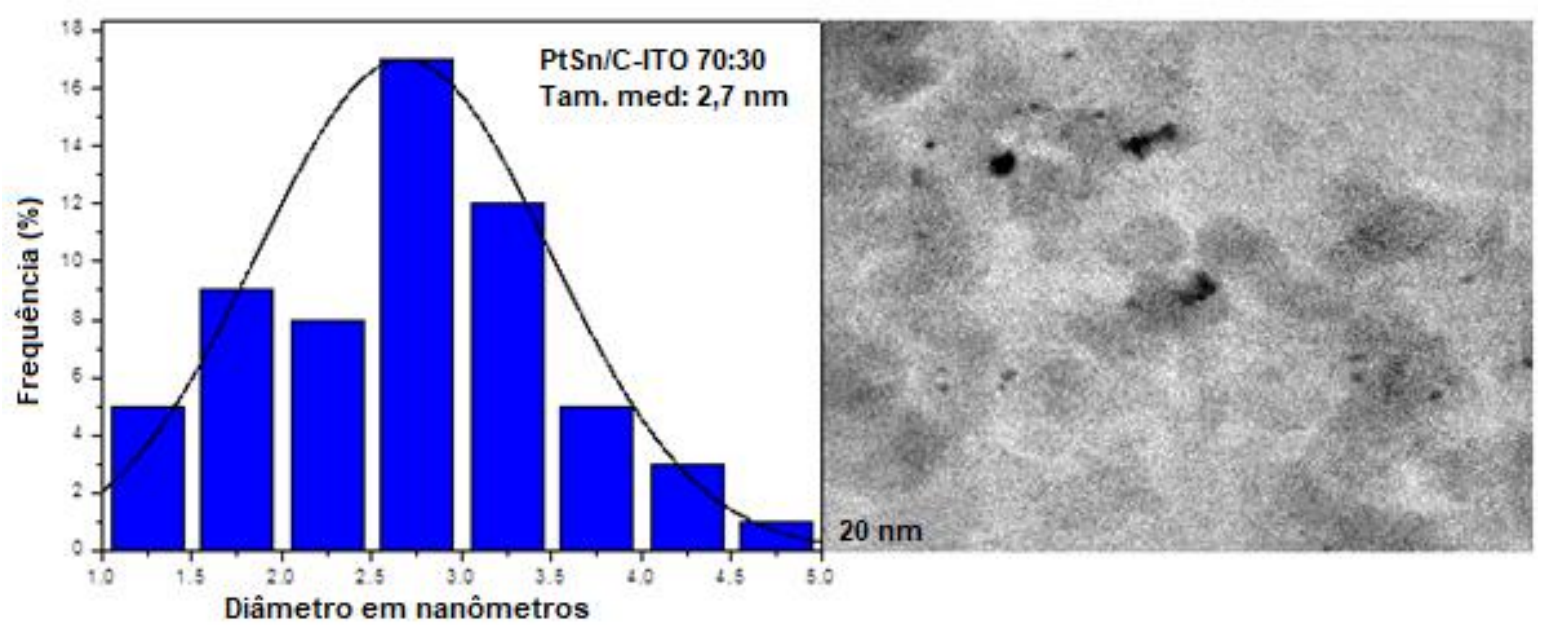

Figura 16. Histograma da distribuição dos tamanhos das partículas do eletrocatalisador PtSn/C-ITO 70:30 e micrografia obtida por MET. 


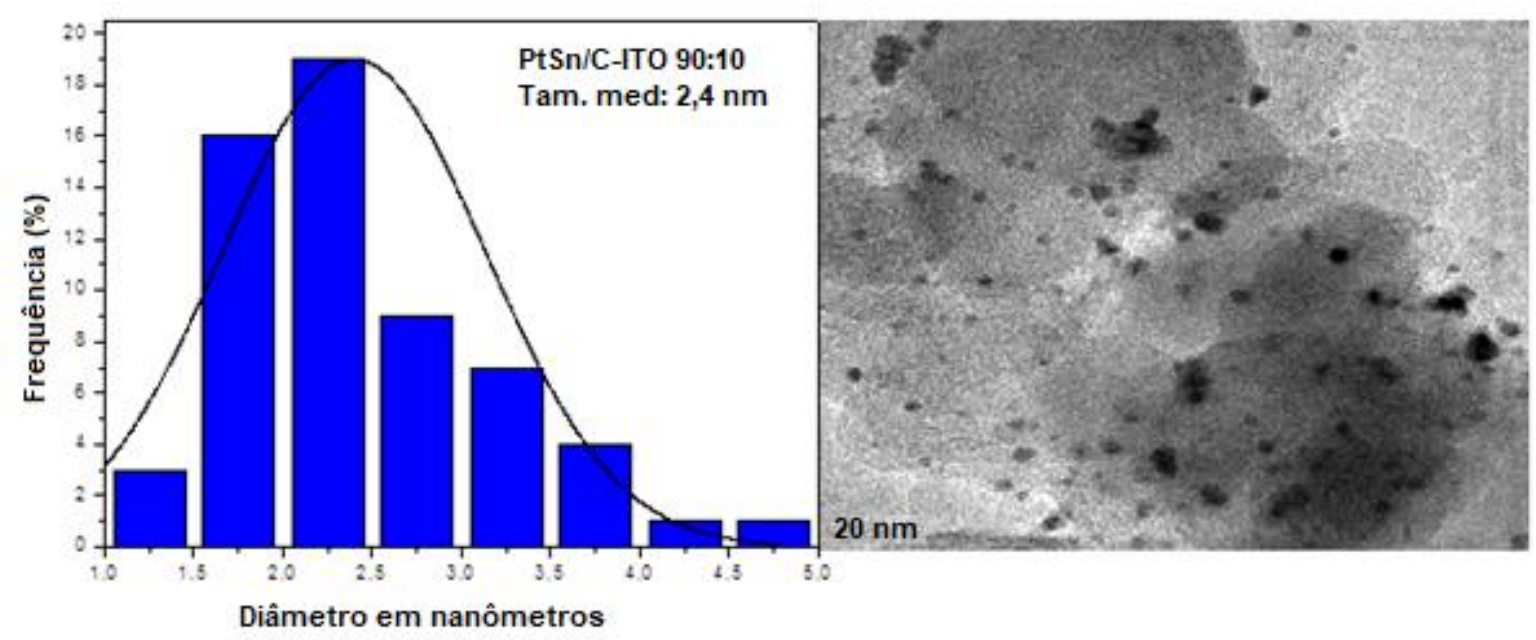

Figura 17. Histograma da distribuição dos tamanhos das partículas do eletrocatalisador PtSn/C-ITO 90:10 e micrografia obtida por MET.

As micrografias dos eletrocatalisadores apresentaram um tamanho médio de partícula muito próximo. A literatura confirma a formação de aglomerados para catalisadores contendo os óxidos de índio e estanho [72]. As concentrações de ITO utilizadas foram de 15\% no suporte de carbono Vulcan XC 72.

A TAB. 5 mostra o tamanho mínimo, médio e máximo das partículas para os eletrocatalisadores estudados pela técnica MET.

TABELA 5. Tamanho mínimo, médio e máximo de partícula para os eletrocatalisadores Pt/C, Pt/C-ITO, PtSn/C 70:30, PtSn/C-ITO 50:50, PtSn/C-ITO 70:30 e PtSn/C-ITO 90:10.

\begin{tabular}{|l|c|c|c|}
\hline & \multicolumn{3}{|c|}{ MET } \\
\cline { 2 - 4 } & $\begin{array}{c}\text { Tamanho } \\
\text { mínimo em } \\
\text { Eletrocatalisador }\end{array}$ & $\begin{array}{c}\text { Tamanho } \\
\text { médio em } \\
\mathbf{n m}\end{array}$ & $\begin{array}{c}\text { Tamanho } \\
\text { máximo em } \\
\text { nm }\end{array}$ \\
\hline Pt/C & 0,52 & 2,2 & 4,1 \\
\hline Pt/C-ITO & 1,1 & 2,5 & 4,4 \\
\hline PtSn/C 70:30 & 1,1 & 2,4 & 4,9 \\
\hline PtSn/C-ITO 50:50 & 1,2 & 2,5 & 3,8 \\
\hline PtSn/C-ITO 70:30 & 1,1 & 2,7 & 4,9 \\
\hline PtSn/C-ITO 90:10 & 1,1 & 2,4 & 4,9 \\
\hline
\end{tabular}


Dong-Ha Lim e colaboradores [78] sintetizaram catalisadores de PtSn/C pelo método de borohidreto de sódio com tamanhos de partículas variando de 1,0 a 4,0 nm. Dados que estão próximos aos valores encontrados para este trabalho, lembrando que a principal diferença foi o uso de 15\% ITO no suporte de carbono Vulcan XC 72 na preparação dos eletrocatalisadores.

\subsection{Medidas eletroquímicas em meio ácido}

\subsubsection{Voltametria cíclica}

A FIG. 18 mostra os voltamogramas cíclicos para os eletrocatalisadores $\mathrm{Pt} / \mathrm{C}, \mathrm{Pt} / \mathrm{C}-I T O, \mathrm{PtSn} / \mathrm{C}$ 70:30, PtSn/C-ITO 50:50, PtSn/C-ITO 70:30 e $\mathrm{PtSn} / \mathrm{C}$-ITO 90:10 com uma velocidade de varredura de $10 \mathrm{mV} \mathrm{s}^{-1}$ em solução de $\mathrm{H}_{2} \mathrm{SO}_{4} 0,5 \mathrm{~mol} \mathrm{~L}^{-1}$ a temperatura ambiente.

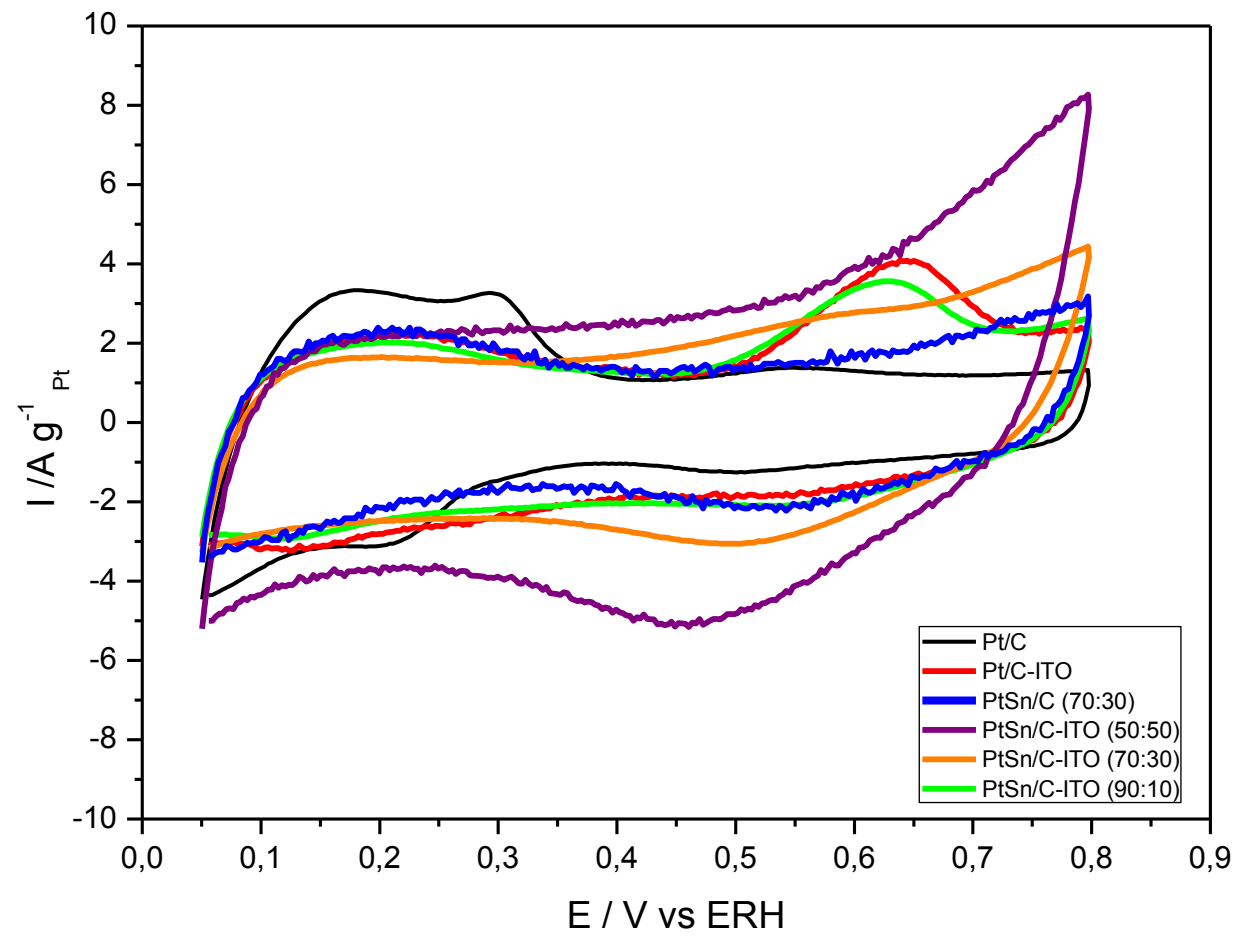

Figura 18. Voltamogramas cíclicos dos eletrocatalisadores Pt/C, Pt/C-ITO, $\mathrm{PtSn} / \mathrm{C}$ 70:30, PtSn/C-ITO 50:50, PtSn/C-ITO 70:30 e PtSn/C-ITO 90:10 em meio ácido $\mathrm{H}_{2} \mathrm{SO}_{4} 0,5 \mathrm{~mol} \mathrm{~L}^{-1}$. 
Os eletrocatalisadores quem contém ITO e o eletrocatalisador de PtSn/C 70:30 nos voltamogramas apresentados mostraram uma região de adsorção/dessorção de hidrogênio pouco definidas com relação ao gráfico de $\mathrm{Pt} / \mathrm{C}$. É possível observar que nas regiões de adsorção/dessorção de hidrogênio $(0,05 \mathrm{~V}$ e $0,4 \mathrm{~V})$ são menos definidas a medida que se aumenta a quantidade de estanho. Provavelmente os sítios da platina se tornam menos disponíveis devido ao recobrimento dos átomos de platina por estanho, por fim impedindo a adsorção de hidrogênio nos sítios de platina, o que segundo a literatura este comportamento é característico da formação de ligas Pt-Sn [79,82,83].

Os eletrocatalisadores Pt/C-ITO, PtSn/C 70:30, PtSn/C-ITO 50:50, $\mathrm{PtSn} / \mathrm{C}$-ITO 70:30 e PtSn/C-ITO 90:10 mostraram um aumento nas correntes para a região da dupla camada elétrica $(0,4$ a $0,8 \quad \mathrm{~V})$ em relação ao eletrocatalisador $\mathrm{Pt} / \mathrm{C}$.

Segunda a literatura este comportamento é explicado pela maior formação de espécies oxigenadas proveniente de uma maior quantidade de estanho na composição dos eletrocatalisadores binários [79].

Para valores acima de $0,5 \mathrm{~V}$ vs $\mathrm{ERH}$ nota-se maiores valores de corrente para os catalisadores PtSn/C-ITO 70:30 e PtSn/C-ITO 50:50 sendo este último o de valor maior. Uma análise da varredura negativa de potenciais também mostrou um aumento nas correntes na região da dupla camada elétrica associado com a redução de óxidos formados durante a varredura positiva de potenciais para os eletrocatalisadores preparados.

\subsubsection{Voltametria cíclica em etanol}

A FIG.19 mostra os voltamogramas cíclicos na presença de etanol 1,0 mol $\mathrm{L}^{-1}$ para os eletrocatalisadores Pt/C, Pt/C-ITO, PtSn/C 70:30, PtSn/C-ITO 50:50, $\mathrm{PtSn} / \mathrm{C}$-ITO 70:30 e PtSn/C-ITO 90:10 com uma velocidade de varredura de $10 \mathrm{mV} \mathrm{s}^{-1}$ em solução de $\mathrm{H}_{2} \mathrm{SO}_{4} 0,5 \mathrm{~mol} \mathrm{~L}^{-1}$ a temperatura ambiente. 


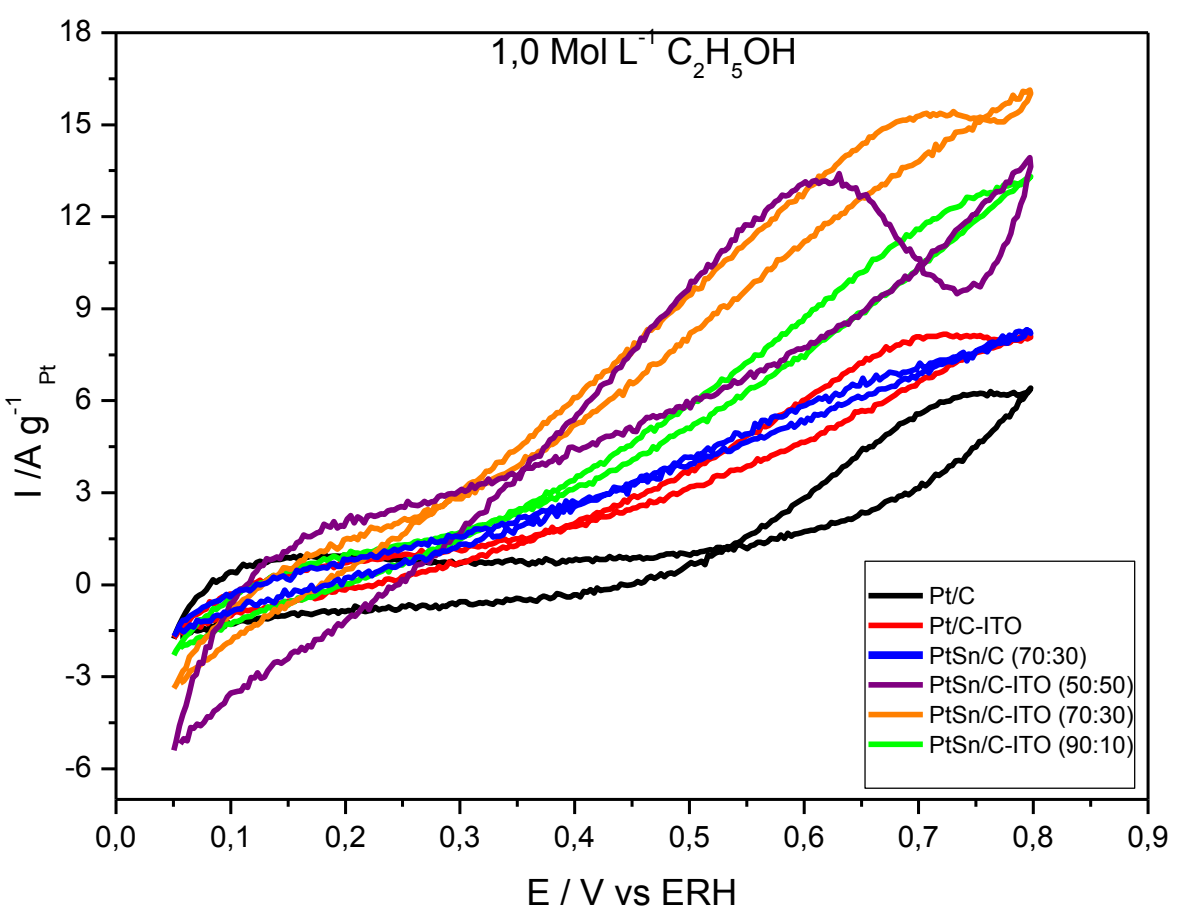

Figura 19. Voltamogramas cíclicos dos eletrocatalisadores Pt/C, Pt/C-ITO, $\mathrm{PtSn} / \mathrm{C}$ 70:30, PtSn/C-ITO 50:50, PtSn/C-ITO 70:30 e PtSn/C-ITO 90:10 em meio ácido $\mathrm{H}_{2} \mathrm{SO}_{4} 0,5 \mathrm{~mol} \mathrm{~L}^{-1}$ na presença de etanol $1 \mathrm{~mol} \mathrm{~L}^{-1}$.

Para auxiliar a interpretação da FIG. 19, construiu-se a TAB. 6 onde estão apresentados os valores do potencial de início da oxidação do etanol referentes aos eletrocatalisadores Pt/C, Pt/C-ITO, PtSn/C 70:30, PtSn/C-ITO 50:50, PtSn/C-ITO 70:30 e PtSn/C-ITO 90:10 em meio ácido $\mathrm{H}_{2} \mathrm{SO}_{4}$ 0,5 mol L-1 na presença de etanol $1 \mathrm{~mol} \mathrm{~L}^{-1}$. 
TABELA 6. Potenciais de início da oxidação do etanol em meio ácido para os eletrocatlisadores de Pt/C, Pt/C-ITO, PtSn/C 70:30, PtSn/C-ITO 50:50, PtSn/C-ITO 70:30 e PtSn/C-ITO 90:10.

\begin{tabular}{|l|c|}
\hline Eletrocatalisador & $\begin{array}{c}\text { Início da oxidação } \\
\text { em etanol para o } \\
\text { meio ácido }\end{array}$ \\
\hline Pt/C & $0,52 \mathrm{~V}$ \\
\hline Pt/C-ITO & $0,35 \mathrm{~V}$ \\
\hline PtSn/C 70:30 & $0,35 \mathrm{~V}$ \\
\hline PtSn/C-ITO 50:50 & $0,35 \mathrm{~V}$ \\
\hline PtSn/C-ITO 70:30 & $0,28 \mathrm{~V}$ \\
\hline PtSn/C-ITO 90:10 & $0,30 \mathrm{~V}$ \\
\hline
\end{tabular}

A eletro-oxidação de etanol sobre o eletrocatalisador Pt/C iniciou-se em, aproximadamente $0,52 \mathrm{~V}$, enquanto para os eletrocatalisadores $\mathrm{Pt} / \mathrm{C}$-ITO, $\mathrm{PtSn} / \mathrm{C}$ 70:30 e PtSn/C-ITO 50:50, o início da oxidação foi em aproximadamente 0,35 V. O eletrocatalisador PtSn/C-ITO 90:10 iniciou a oxidação do etanol em aproximadamente $0,30 \mathrm{~V}$, estes resultados indicam o efeito benéfico da adição do co-catalisador a platina pura.

Todos os eletrocatalisadores apresentaram maiores valores de corrente quando comparados ao eletrocalisador de $\mathrm{Pt} / \mathrm{C}$, destacando-se $\mathrm{o}$ eletrocatalisador PtSn/C-ITO 70:30, que começou a oxidar o etanol a um potencial próximo a $0,28 \mathrm{~V}$.

O bom desempenho dos eletrocatalisadores pode ser atribuído principalmente ao uso do segundo metal, o Sn quando relacionamos aos voltamogramas dos eletrocatalisadores $\mathrm{Pt} / \mathrm{C}$ e $\mathrm{Pt} / \mathrm{C}$-ITO. Isto pode ser explicado pela presença do estanho fornecendo espécies oxigenadas [80,81] (mecanismo bifuncional) e/ou ao efeito eletrônico [87], facilitando assim a oxidação dos intermediários fortemente adsorvidos e por fim permitindo novas adsorções das moléculas de etanol. Pelos resultados de DRX obtidos neste trabalho, é possível afirmar que houve a formação de uma liga Pt-Sn a uma certa extensão e também a presença de óxidos de $\mathrm{Sn}$ e de In no eletrocatalisador sintetizado via redução por borohidreto de sódio, consequentemente isto nos permite inferir que tanto 0 mecanismo bifuncional quanto o efeito eletrônico devem ocorrer na oxidação dos eletrocatalisadores que contém Sn. 


\subsubsection{Cronoamperometria}

A FIG. 20 mostra os resultados da técnica de cronoamperometria para os eletrocatalisadores Pt/C, Pt/C-ITO, PtSn/C 70:30, PtSn/C-ITO 50:50, $\mathrm{PtSn} / \mathrm{C}-\mathrm{ITO}$ 70:30 e PtSn/C-ITO 90:10 obtidos na presença de $\mathrm{H}_{2} \mathrm{SO}_{4}$ 0,5 mol L${ }^{1}$ e de etanol $1 \mathrm{~mol} \mathrm{~L}^{-1}$ a temperatura ambiente. Para os estudos com a técnica de cronoamperometria fixou-se o potencial em $0,5 \mathrm{~V}$ por 30 minutos.

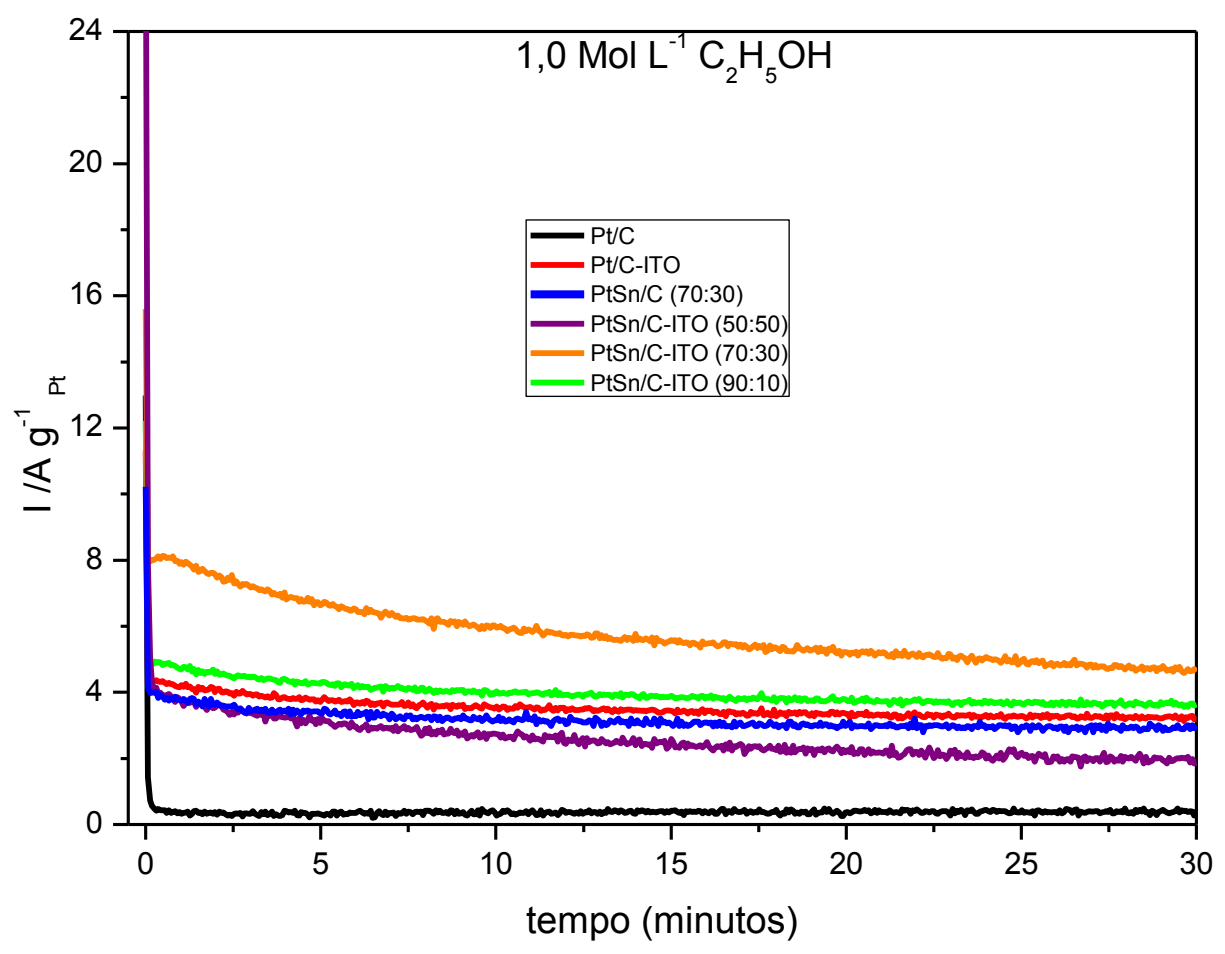

Figura 20. Curva cronoamperométrica para os eletrocatalisadores $\mathrm{Pt} / \mathrm{C}, \mathrm{Pt} / \mathrm{C}$ ITO, PtSn/C 70:30, PtSn/C-ITO 50:50, PtSn/C-ITO 70:30 e PtSn/C-ITO 90:10 na presença de $0,5 \mathrm{~mol} \mathrm{~L}^{-1} \mathrm{H}_{2} \mathrm{SO}_{4}$ e de etanol $1 \mathrm{~mol} \mathrm{~L}^{-1}$.

Em todas as curvas cronoamperométricas há uma queda inicial acentuada de corrente, posteriormente estes valores sofrem um pequeno decréscimo até os 5 minutos iniciais. O eletrocatalisador PtSn/C-ITO 50:50 apresentou menores valores de corrente durante os 30 minutos de operação, apresentando o pior desempenho entre os eletrocatalisadores com e Sn e ITO, indicando provavelmente que muito estanho recobre os sítios ativos de platina 
para adsorção de etanol. Segundo Zhou et al. [75] o aumento na quantidade de Sn pode influenciar em uma maior formação de espécies oxigenadas na superfície do eletrodo, alterações do parâmetro de rede e resistência ôhmica, indicando que uma composição ótima de Sn estaria em torno de 30\% em massa, proporção encontrada por Zhou et al. [75] e também por outros autores para melhor atividade eletrocatalítica do Sn $[82,83]$, no entanto é sabido que os resultados presentes na literatura são contraditórios e as diferenças desses resultados estão associados às diferentes metodologias empregadas pelos pesquisadores, o que de certa forma dificulta a comparação dos resultados em metodologias que não são iguais.

A TAB. 7 mostra os valores de corrente para oxidação do etanol após 30 minutos de operação para os eletrocaltalisadores Pt/C, Pt/C-ITO, PtSn/C 70:30, PtSn/C-ITO 50:50, PtSn/C-ITO 70:30 e PtSn/C-ITO 90:10 fixados em um potencial de $0,5 \mathrm{~V}$ para o meio ácido.

TABELA 7. Valores de oxidação após 30 minutos de operação pela técnica de cronoamperometria em meio ácido para os eletrocatalisadores $\mathrm{Pt} / \mathrm{C}, \mathrm{Pt} / \mathrm{C}-\mathrm{ITO}$, PtSn/C 70:30, PtSn/C-ITO 50:50, PtSn/C-ITO 70:30 e PtSn/C-ITO 90:10.

\begin{tabular}{|l|c|}
\hline & \\
\hline Eletrocatalisador & Meio ácido $\mathbf{~} / \mathbf{A ~}^{-1} \mathbf{~} \mathbf{~}$ \\
\hline Pt/C & 0,43 \\
\hline Pt/C-ITO & 3,18 \\
\hline PtSn/C 70:30 & 3,01 \\
\hline PtSn/C-ITO 50:50 & 1,87 \\
\hline PtSn/C-ITO 70:30 & 4,62 \\
\hline PtSn/C-ITO 90:10 & 3,63 \\
\hline
\end{tabular}

A técnica de cronoamperometria mostrou que o catalisador com melhor desempenho é o PtSn/C-ITO 70:30, apresentando valor de corrente maior ao final da análise. Uma comparação de PtSn/C-ITO 70:30 com Pt/C mostra que os eletrocatalisador proposto neste trabalho tem cerca de 10 vezes mais atividade do que platina pura, portanto eletrocatalisadores do tipo PtSn/C-ITO são promissores para os experimentos em células a combustível alimentadas 
diretamente por etanol. O eletrocatalisador Pt/C-ITO também mostra uma modificação no desempenho da platina pura o que viabiliza o estudo e 0 desenvolvimento de novos suportes em células a combustível.

\subsection{Medidas em célula combustível unitária em meio ácido}

A FIG. 21 mostra o desempenho eletroquímico em meio ácido dos experimentos em célula unitária para eletrocatalisadores $\mathrm{Pt} / \mathrm{C}, \mathrm{Pt} / \mathrm{C}$-ITO, PtSn/C 70:30, PtSn/C-ITO 50:50, PtSn/C-ITO 70:30, PtSn/C-ITO 90:10 empregados no ânodo e alimentados por etanol.

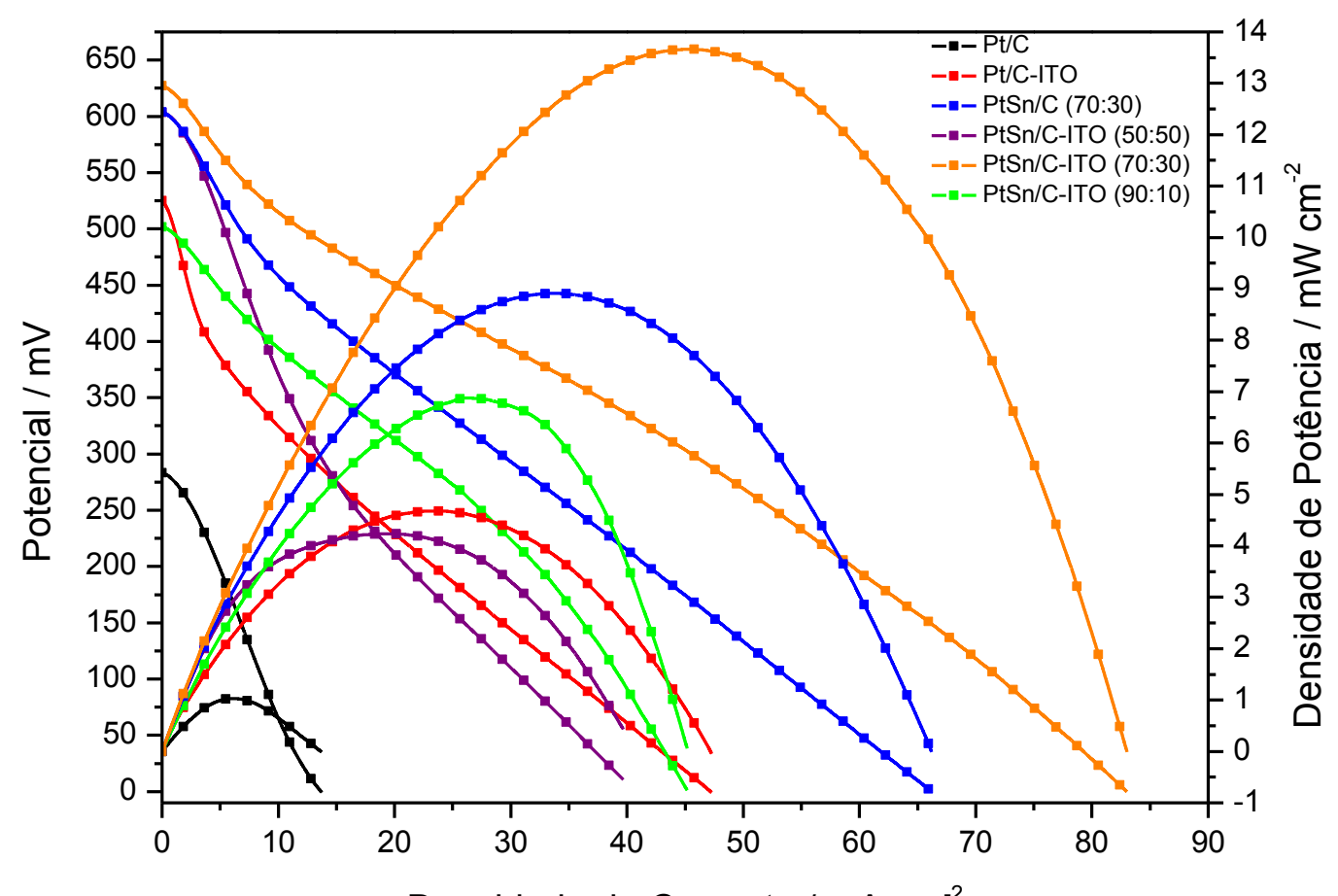

Densidade de Corrente / $\mathrm{mA} \mathrm{cm}^{-2}$

Figura 21. Curvas de Polarização para Pt/C, Pt/C-ITO, PtSn/C 70:30, $\mathrm{PtSn} / \mathrm{C}$-ITO 50:50, PtSn/C-ITO 70:30 e PtSn/C-ITO 90:10, fluxo $=1 \mathrm{~mL} \mathrm{~min}{ }^{-1} \mathrm{de}$ solução etanol 2 mols $\mathrm{L}^{-1}$. Cátodo alimentado com 2 bar de oxigênio puro. Temperatura de operação da célula $=100^{\circ} \mathrm{C}$. Temperatura garrafa umidificadora $=85^{\circ} \mathrm{C}$. 
Para facilitar a visualização dos valores da FIG. 21, elaborou-se a TAB. 8 que mostra os valores de potencial de circuito aberto em $\mathrm{mV}$ e densidade de corrente em $\mathrm{mW}$ obtidos pelos experimentos em célula unitária em meio ácido para os eletrocatalisadores Pt/C, Pt/C-ITO, PtSn/C 70:30, PtSn/C-ITO 50:50, PtSn/C-ITO 70:30 e PtSn/C-ITO 90:10.

TABELA 8. Potencial de circuito aberto em $\mathrm{mV}$ e densidade de corrente em $\mathrm{mW}$ obtidos pelos experimentos em célula unitária em meio ácido para os eletrocatalisadores Pt/C, Pt/C-ITO, PtSn/C 70:30, PtSn/C-ITO 50:50, PtSn/CITO 70:30 e PtSn/C-ITO 90:10.

\begin{tabular}{|l|c|c|}
\hline Eletrocatalisador & $\begin{array}{c}\text { Potencial de circuito } \\
\text { aberto em } \mathbf{~ m V}\end{array}$ & $\begin{array}{c}\text { Densidade de } \\
\text { corrente em mW }\end{array}$ \\
\hline Pt/C & 283 & 1,03 \\
\hline Pt/C-ITO & 524 & 4,68 \\
\hline PtSn/C 70:30 & 603 & 8,91 \\
\hline PtSn/C-ITO 50:50 & 603 & 4,23 \\
\hline PtSn/C-ITO 70:30 & 627 & 13,6 \\
\hline PtSn/C-ITO 90:10 & 501 & 6,87 \\
\hline
\end{tabular}

O eletrocatalisador PtSn/C-ITO 70:30 apresentou o maior valor de densidade de potência e potencial de circuito aberto dentre todos os eletrocatalisadores nos experimentos em célula unitária em meio ácido.

Os eletrocatalisadores $\mathrm{Pt} / \mathrm{C}, \mathrm{Pt} / \mathrm{C}$-ITO e os eletrocatalisadores $\mathrm{PtSn} / \mathrm{C}$ 70:30, PtSn/C-ITO 70:30, se diferenciam apenas pela adição de ITO ao suporte de carbono Vulcan XC 72 (em torno de 15\%). Com base nesta diferença foi possível notar de maneira mais incisa o efeito benéfico dos óxidos de estanho e índio (ITO). A voltagem do potencial de circuito aberto para a célula a combustível contendo o eletrocatalisador $\mathrm{Pt} / \mathrm{C}$ foi de $283 \mathrm{mV}$, enquanto que para o eletrocatalisador Pt/C-ITO o potencial de circuito aberto foi superado encontrando-se o valor de $524 \mathrm{mV}$. A densidade de potência máxima para o eletrocatalisador $\mathrm{Pt} / \mathrm{C}$ foi de $1,03 \mathrm{~mW} \mathrm{~cm}^{-2}$, enquanto que para o sistema $\mathrm{Pt} / \mathrm{C}$ ITO o valor encontrado foi de $4,68 \mathrm{~mW} \mathrm{~cm}^{-2}$.

Os eletrocatalisadores $\mathrm{PtSn} / \mathrm{C}$ 70:30 e PtSn/C-ITO 70:30 possuem aproximadamente $30 \%$ de Sn. Fato que como dito por Zhou et. al [75] e outros 
colaboradores $[82,83]$ demonstra ser a composição ótima de estanho em eletrocatalisadores de Pt para a oxidação de etanol. Verificou-se que a voltagem do potencial de circuito aberto para a célula a combustível contendo o eletrocatalisador PtSn/C 70:30 foi de $603 \mathrm{mV}$, enquanto que para o eletrocatalisador PtSn/C-ITO 70:30 o potencial de circuito aberto foi superado encontrando-se o valor de $627 \mathrm{mV}$.

A densidade de potência máxima para o eletrocatalisador PtSn/C 70:30 foi de $8,91 \mathrm{~mW} \mathrm{~cm}^{-2}$, enquanto que para o sistema PtSn/C-ITO 70:30 o valor encontrado foi de $13,6 \mathrm{~mW} \mathrm{~cm}^{-2}$.

De acordo com a literatura descrita nesse trabalho, $\mathrm{Sn}$ e ITO proporcionam espécies oxigenadas em potenciais de oxidação menores, contribuindo com a oxidação de intermediários como o $\mathrm{CO}, \mathrm{C}_{2} \mathrm{H}_{4} \mathrm{O}$ e $\mathrm{CH}_{3} \mathrm{COOH}$ que envenenam os sítios ativos da Pt na oxidação do etanol. Portanto, estes resultados, demonstram e comprovam a eficácia do uso do Sn e do ITO como agentes promotores para oxidação de intermediários e para o aumento da atividade eletrocatalítica em células PEMFC em meio ácido que usam etanol como combustível. É importante salientar que estes resultados estão de acordo com resultados eletroquímicos, ou seja, os sistemas PtSn/C-ITO apresentam densidades de potência dez vezes maiores que $\mathrm{Pt} / \mathrm{C}$ indicando que esta nova geração de materiais são promissores para os estudos em células a combustível atestando a importância do trabalho desenvolvido, no entanto ainda são necessários informações com respeito a formação e distribuição dos produtos de oxidação do etanol obtidos tanto por rotas eletroquímicas quanto nos experimentoss em células a combustível.

\subsection{Medidas eletroquímicas em meio alcalino.}

Nos últimos anos tem sido reportado estudos para a oxidação do etanol em meio alcalino, muitos destes estudos são realizados a temperatura ambiente e a maioria destes estudos não envolvem estudos em células alcalinas alimentadas diretamente por etanol. Também é visto resultados contraditórios quanto o eletrocatalisador mais ativo para a oxidação do etanol em meio alcalino, ou seja, Paládio tem sido relatado como mais ativo para a oxidação do etanol em relação a platina pura, no entanto quando combinado com um co-catalisador 
tem sem mostrado menos ativo que o sistema binário de platina, estas mudanças estão relacionadas aos diferentes métodos empregado na literatura. É importante salientar que a cinética da oxidação do etanol em meio alcalino é mais rápida do que em meio ácido, como o meio é menos agressivo, no entanto em meio alcalino há a formação de carbonatos que podem entupir a estrutura porosa do eletrodo de difusão gasosa, portanto estudos em meio alcalino são de extrema importância para o avanço dos estudos em células a combustível, por fim os resultados aqui obtidos se fazem importantes.

\subsubsection{Voltametria cíclica}

A FIG.22 mostra os voltamogramas cíclicos para os eletrocatalisadores $\mathrm{Pt} / \mathrm{C}, \mathrm{Pt} / \mathrm{C}$-ITO, PtSn/C 70:30, PtSn/C-ITO 50:50, PtSn/C-ITO 70:30 e PtSn/CITO 90:10 com uma velocidade de varredura de $10 \mathrm{mV} \mathrm{s}^{-1}$ em solução de $\mathrm{KOH}$ $1 \mathrm{~mol} \mathrm{~L}^{-1}$ à temperatura ambiente.

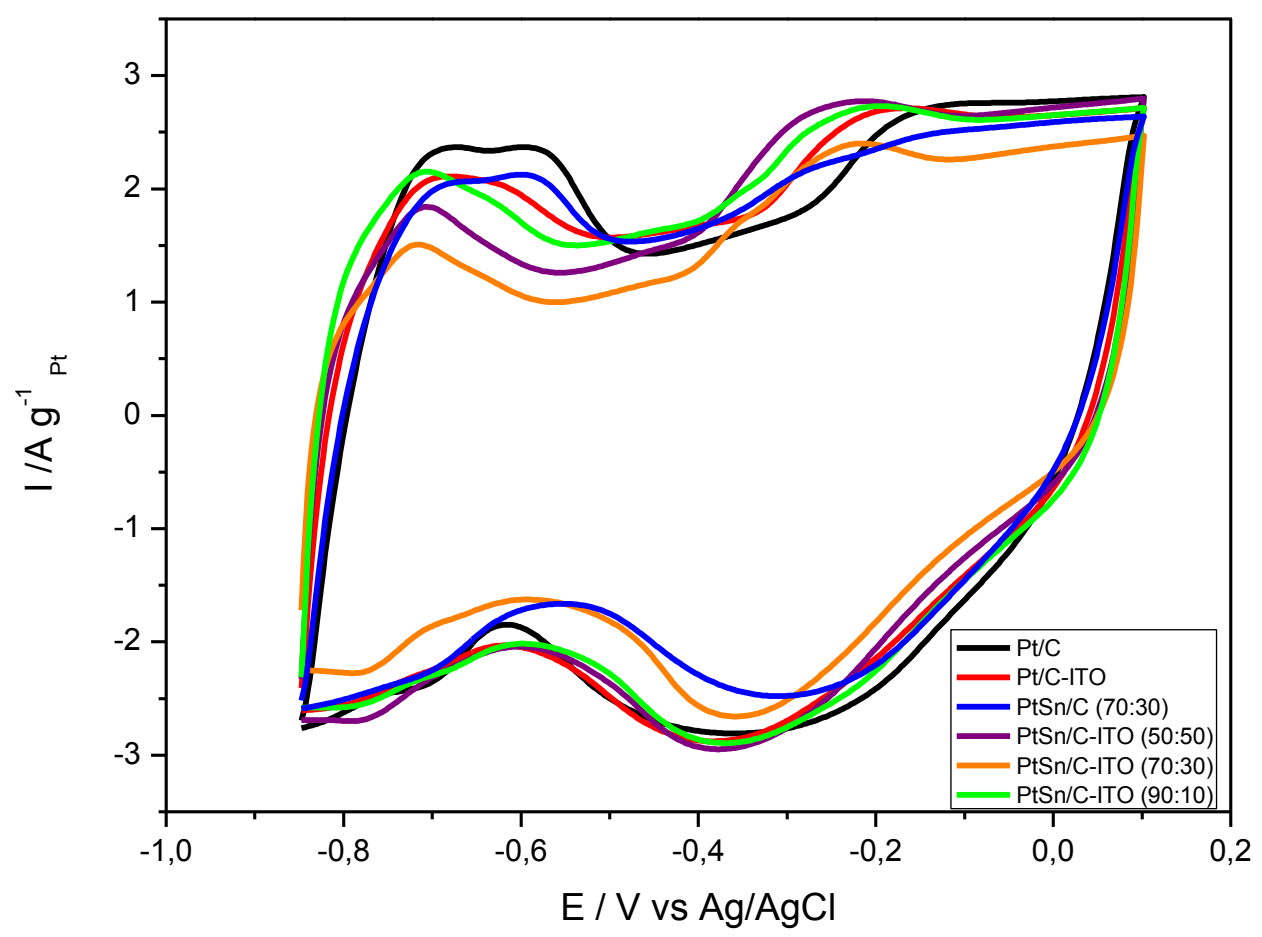


Figura 22. Voltamogramas cíclicos dos eletrocatalisadores $\mathrm{Pt} / \mathrm{C}, \mathrm{Pt} / \mathrm{C}-\mathrm{ITO}$, $\mathrm{PtSn} / \mathrm{C}$-ITO 50:50, PtSn/C 70:30, PtSn/C-ITO 70:30 e PtSn/C-ITO 90:10 em meio alcalino $\mathrm{KOH} 1,0 \mathrm{~mol} \mathrm{~L}^{-1}$.

Todos os eletrocatalisadores apresentaram uma região de adsorção com corrente menor em relação ao eletrocatalisador de $\mathrm{Pt} / \mathrm{C}$. Provavelmente isso se deve ao fato de haver um recobrimento de sítios de platina disponíveis para adsorção de hidrogênio, no entanto diferente do que foi observado no meio ácido a formação de óxidos de estanho parece não ocorrer em meio alcalino. Consequentemente, a adição do Sn nestes catalisadores pode não trazer um benefício para a oxidação do etanol em meio alcalino se comparados com o meio ácido, isso pode ser visto pela similaridade dos voltamogramas expostos.

\subsubsection{Voltametria cíclica em etanol}

A FIG.23 ilustra os voltamogramas cíclicos na presença de etanol $1,0 \mathrm{~mol} \mathrm{~L}^{-1}$ para os eletrocatalisadores $\mathrm{Pt} / \mathrm{C}, \mathrm{Pt} / \mathrm{C}-\mathrm{ITO}, \mathrm{PtSn} / \mathrm{C}$ 70:30, PtSn/C-ITO 50:50, PtSn/C-ITO 70:30 e PtSn/C-ITO 90:10 com uma velocidade

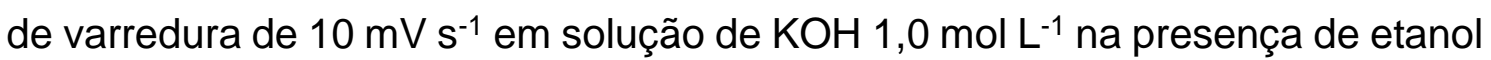
$1,0 \mathrm{~mol} \mathrm{~L}^{-1}$ à temperatura ambiente. 


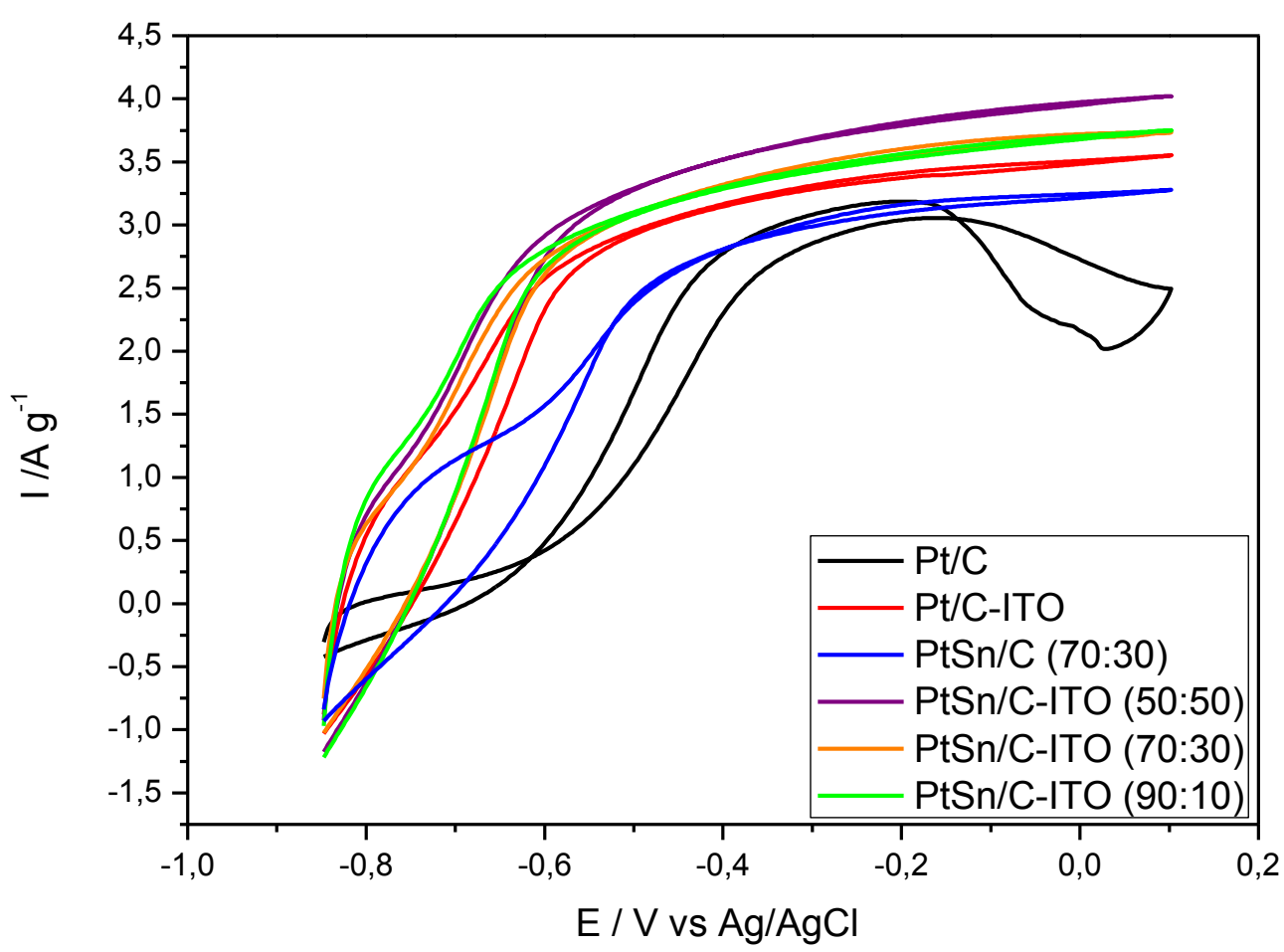

Figura 23. Voltamogramas cíclicos dos eletrocatalisadores $\mathrm{Pt} / \mathrm{C}, \mathrm{Pt} / \mathrm{C}$-ITO, $\mathrm{PtSn} / \mathrm{C}$ 70:30, PtSn/C-ITO 50:50, PtSn/C-ITO 70:30 e PtSn/C-ITO 90:10 em meio alcalino $\mathrm{KOH} 1,0 \mathrm{~mol} \mathrm{~L}^{-1}$ na presença de etanol $1 \mathrm{~mol} \mathrm{~L}^{-1}$.

Para auxiliar a interpretação da FIG. 23, construiu-se a TAB. 9 onde estão apresentados os valores do potencial de início da oxidação do etanol referentes aos eletrocatalisadores Pt/C, Pt/C-ITO, PtSn/C 70:30, PtSn/C-ITO 50:50, $\mathrm{PtSn} / \mathrm{C}$-ITO 70:30 e PtSn/C-ITO 90:10 em meio alcalino $\mathrm{KOH}$ 1,0 mol L-1 na presença de etanol $1 \mathrm{~mol} \mathrm{~L}^{-1}$.

TABELA 9. Potenciais de início da oxidação do etanol em meio alcalino para os eletrocatlisadores Pt/C, Pt/C-ITO, PtSn/C 70:30, PtSn/C-ITO 50:50, PtSn/C-ITO 70:30 e PtSn/C-ITO 90:10.

\begin{tabular}{|l|c|}
\hline Eletrocatalisador & $\begin{array}{c}\text { Início da oxidação } \\
\text { em etanol para o } \\
\text { meio alcalino }\end{array}$ \\
\hline Pt/C & $-0,60 \mathrm{~V}$ \\
\hline
\end{tabular}




\begin{tabular}{|l|l|} 
Pt/C-ITO & $-0,80 \mathrm{~V}$ \\
\hline PtSn/C (70:30) & $-0,83 \mathrm{~V}$ \\
\hline PtSn/C-ITO (50:50) & $-0,80 \mathrm{~V}$ \\
\hline PtSn/C-ITO (70:30) & $-0,80 \mathrm{~V}$ \\
\hline PtSn/C-ITO (90:10) & $-0,80 \mathrm{~V}$ \\
\hline
\end{tabular}

A eletro-oxidação de etanol sobre o eletrocatalisador Pt/C iniciou-se em, aproximadamente - 0,60 V, enquanto para os eletrocatalisadores Pt/C-ITO, $\mathrm{PtSn} / \mathrm{C}$-ITO 50:50, PtSn/C-ITO 70:30, PtSn/C-ITO 90:10 o início da oxidação foi aparentemente na mesma região de $-0,80 \mathrm{~V}$. O eletrocatalisador PtSn/C 70:30 iniciou a oxidação do etanol em aproximadamente $-0,83 \mathrm{~V}$.

Todos os eletrocatalisadores apresentaram maiores valores de corrente quando comparados ao eletrocalisador de $\mathrm{Pt} / \mathrm{C}$, de certa forma, houve um efeito benéfico para adição de estanho e ITO a platina. Os eletrocatalisadores com Sn e/ou ITO, apresentaram um perfil similar nas voltametrias, destacando-se o eletrocatalisador PtSn/C-ITO 50:50 por apresentar maior valor de corrente. Rizo e colaboradores prepararam catalisadores pelo método do ácido fórmico para oxidação do etanol em meio alcalino na presença de $0,1 \mathrm{~mol} \mathrm{NaOH}$ e encontraram melhor atividade para o eletrocatalisador PtSn/C 1:1 (50:50) [90]. Trabalhos utilizando o método de redução por borohidreto de sódio para oxidação de etanol em meio alcalino para eletrocatalisadores $\mathrm{PtSn} / \mathrm{C}$ e PtSn/CITO não foram encontrados até o presente momento.

\subsubsection{Cronoamperometria}

A FIG. 24 mostra os resultados da técnica de cronoamperometria para os eletrocatalisadores Pt/C, Pt/C-ITO, PtSn/C 70:30, PtSn/C-ITO 50:50,

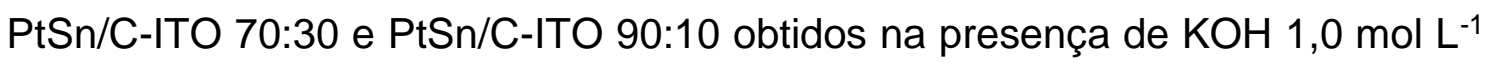
e etanol $1 \mathrm{~mol} \mathrm{~L}^{-1}$ a temperatura ambiente. Para os estudos com a técnica de cronoamperometria fixou-se o potencial em $-0.4 \mathrm{~V}$ por 30 minutos. 


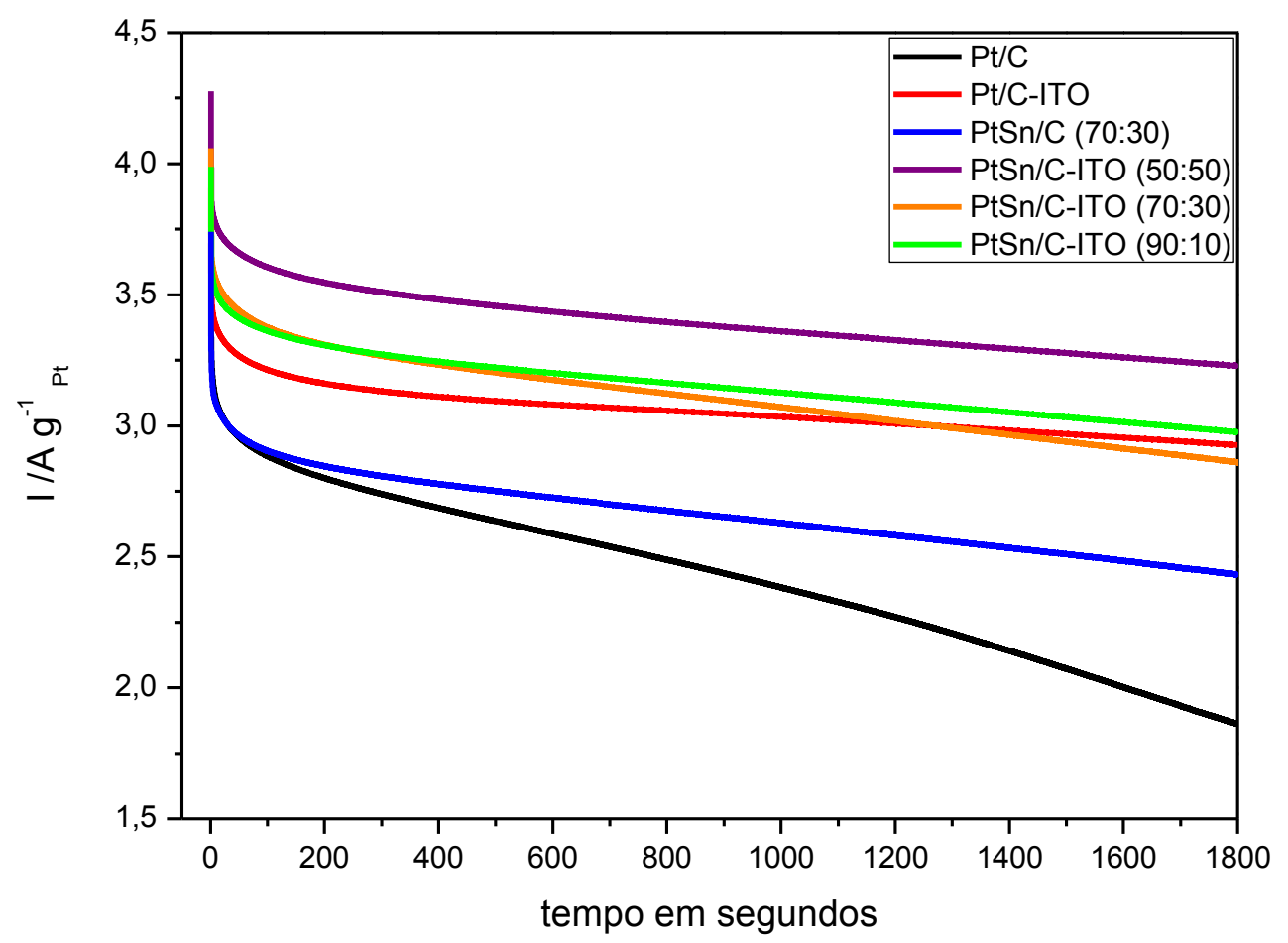

Figura 24. Curva cronoamperométrica para os eletrocatalisadores $\mathrm{Pt} / \mathrm{C}, \mathrm{Pt} / \mathrm{C}$ ITO, PtSn/C 70:30, PtSn/C-ITO 50:50, PtSn/C-ITO 70:30 e PtSn/C-ITO 90:10 na presença de $1,0 \mathrm{~mol} \mathrm{~L}^{-1}$ de $\mathrm{KOH}$ e etanol $1 \mathrm{~mol} \mathrm{~L}^{-1}$.

Em todas as curvas cronoamperométricas há uma queda inicial acentuada de corrente, posteriormente estes valores sofrem um pequeno decréscimo até os 200 segundos iniciais. O eletrocatalisador PtSn/C 70:30 apresentou menor corrente após os 30 minutos de operação entre os eletrocatalisadores com e Sn e ITO, indicando que a ausência do ITO causou menor desempenho, fato que foi confirmado ao comparar-se com 0 eletrocatalisador PtSn/C-ITO 70:30.

A TAB. 10 mostra os valores de corrente para oxidação do etanol após 1800 segundos de operação para os eletrocaltalisadores Pt/C, Pt/C-ITO, PtSn/C 70:30, PtSn/C-ITO 50:50, PtSn/C-ITO 70:30 e PtSn/C-ITO 90:10 fixados em um potencial de $-0,4 \mathrm{~V}$ para o meio alcalino. 
TABELA 10. Valores de oxidação após 1800 segundos de operação pela técnica de cronoamperometria em meio alcalino para os eletrocatalisadores $\mathrm{Pt} / \mathrm{C}, \mathrm{Pt} / \mathrm{C}$ ITO, PtSn/C 70:30, PtSn/C-ITO 50:50, PtSn/C-ITO 70:30 e PtSn/C-ITO 90:10.

\begin{tabular}{|l|c|}
\hline & \\
Eletrocatalisador & Meio alcalino I/A $\mathbf{~ g}^{-1} \mathbf{~ P t}$ \\
\hline Pt/C & 1,86 \\
\hline Pt/C-ITO & 2,92 \\
\hline PtSn/C (70:30) & 2,43 \\
\hline PtSn/C-ITO (50:50) & 3,22 \\
\hline PtSn/C-ITO (70:30) & 2,85 \\
\hline PtSn/C-ITO (90:10) & 2,95 \\
\hline
\end{tabular}

O eletrocatalisador que apresentou melhor desempenho foi 0 $\mathrm{PtSn} / \mathrm{C}$-ITO 50:50, fato também comprovado no voltamograma com etanol. Isto confirma o efeito benéfico do estanho na composição dos eletrocatalisadores preparados. Em termos de corrente final PtSn/C-ITO mostrou 2 vezes mais corrente do que $\mathrm{Pt} / \mathrm{C}$, diferente do que foi observado em meio ácido, de certa forma atestando que estes sistemas são mais efetivos no meio ácido do que em eletrólito alcalino, no entanto em meio alcalino Pt/C sofre uma menor desativação em relação aos estudos em meio ácido, este efeito pode estar relacionado a interação da platina com espécies $\mathrm{OH}$ do meio reacional, em meio ácido estas espécies são formadas em potenciais acima de 0,6 V.

\subsection{Medidas em célula combustível unitária em meio alcalino}

A FIG. 25 mostra o desempenho eletroquímico em meio alcalino dos experimentos em célula unitária com eletrocatalisadores Pt/C, Pt/C-ITO, PtSn/C 70:30, PtSn/C-ITO 50:50, PtSn/C-ITO 70:30, PtSn/C-ITO 90:10 empregados no ânodo e alimentados por etanol. 


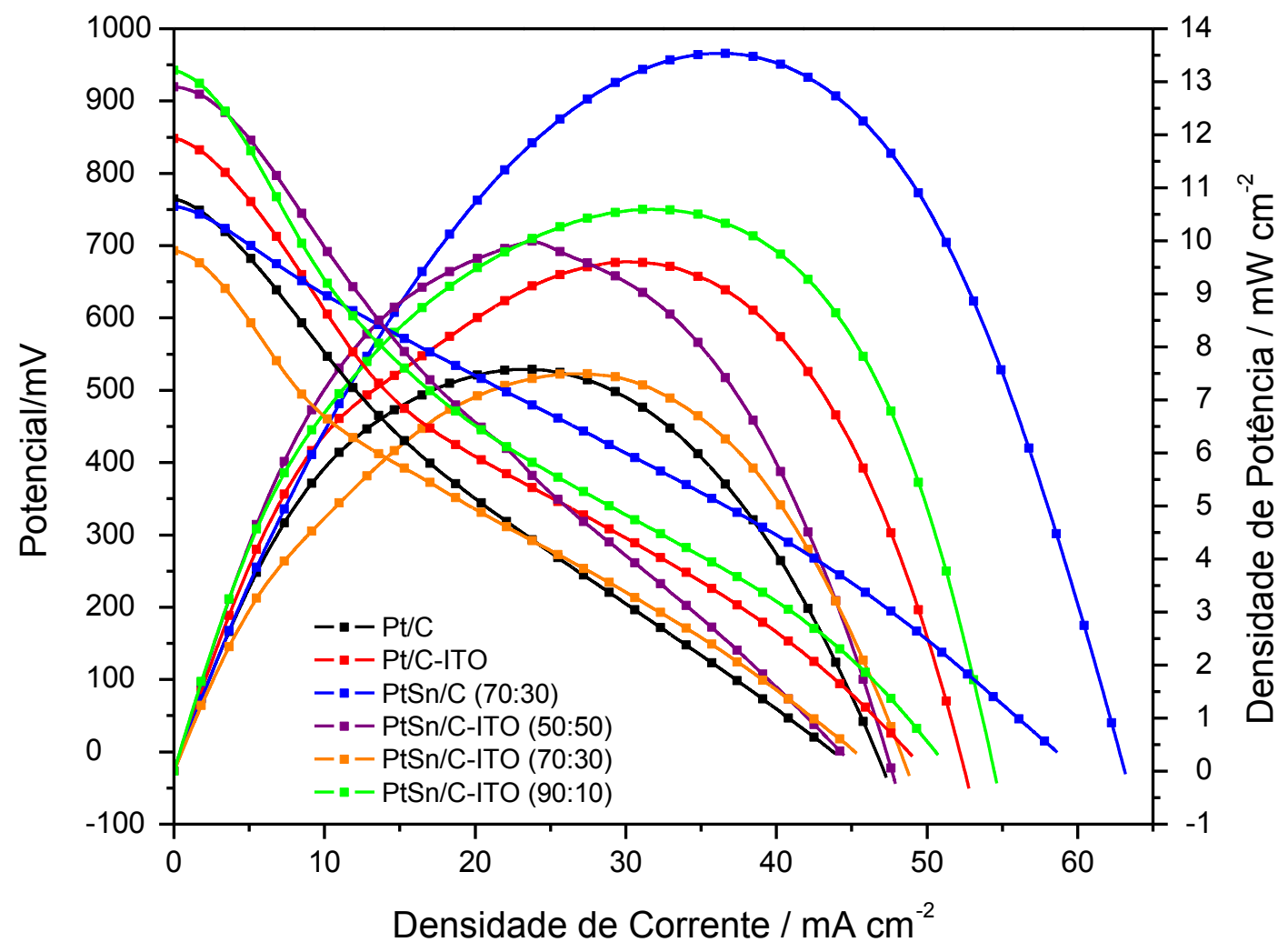

Figura 25. Curvas de Polarização para Pt/C, Pt/C-ITO, PtSn/C 70:30, PtSn/C-

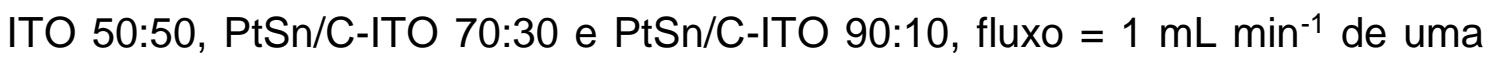
solução etanol $2 \mathrm{~mol} \mathrm{~L}^{-1}$ de $\mathrm{KOH}$ na presença de 2,0 $\mathrm{mol} \mathrm{L}^{-1}$ de etanol. O cátodo foi mantido sob fluxo de oxigênio de $150 \mathrm{~mL} \mathrm{~min}^{-1}$. Temperatura de operação da célula $=100^{\circ} \mathrm{C}$. Temperatura garrafa umidificadora $=85^{\circ} \mathrm{C}$.

Para facilitar a visualização dos valores da FIG. 25, elaborou-se a TAB. 11 que mostra os valores de potencial de circuito aberto em $\mathrm{mV}$ e densidade de corrente em $\mathrm{mW}$ obtidos pelos experimentos em célula unitária em meio alcalino para os eletrocaltalisadores Pt/C, Pt/C-ITO, PtSn/C 70:30, PtSn/C-ITO 50:50, PtSn/C-ITO 70:30 e PtSn/C-ITO 90:10. 
TABELA 11. Potencial de circuito aberto em $\mathrm{mV}$ e densidade de corrente em $\mathrm{mW}$ obtidos pelos experimentos em célula unitária em meio alcalino para os eletrocatalisadores Pt/C, Pt/C-ITO, PtSn/C 70:30, PtSn/C-ITO 50:50, PtSn/C-ITO 70:30 e PtSn/C-ITO 90:10.

\begin{tabular}{|l|c|c|}
\hline Eletrocatalisador & $\begin{array}{c}\text { Potencial de circuito } \\
\text { aberto em } \mathbf{~ m V}\end{array}$ & $\begin{array}{c}\text { Densidade de } \\
\text { corrente em mW }\end{array}$ \\
\hline Pt/C & 764 & 7,58 \\
\hline Pt/C-ITO & 848 & 9,60 \\
\hline PtSn/C 70:30 & 754 & 13,5 \\
\hline PtSn/C-ITO 50:50 & 920 & 10,0 \\
\hline PtSn/C-ITO 70:30 & 693 & 7,50 \\
\hline PtSn/C-ITO 90:10 & 942 & 10,6 \\
\hline
\end{tabular}

Os eletrocatalisadores PtSn/C-ITO 90:10 e PtSn/C-ITO 50:50 apresentaram os maiores valores de potencial de circuito aberto com valores próximos de $942 \mathrm{mV}$ e $920 \mathrm{mV}$ respectivamente. O eletrocatalisador PtSn/C 70:30 apresentou potencial de circuito aberto de $693 \mathrm{mV}$ e dentre todos os eletrocatalisadores em estudo, este foi o que apresentou menor resistência ôhmica. O eletrocatalisador Pt/C apresentou maior potencial de circuito aberto com relação aos eletrocatalisadores PtSn/C 70:30 e PtSn/C-ITO 70:30, entretanto, ele também foi o eletrocatalisador que apresentou maior resistência ôhmica, neste sentido a adição de Sn e ITO foi benéfica.

A densidade de potência máxima foi maior para o eletrocatalisador $\mathrm{PtSn} / \mathrm{C}$ 70:30 com um valor de 13,5 mW. É provável que a menor resistência ôhmica justifique o valor mais elevado de densidade de potência dentre todos os eletrocatalisadores estudados.

Estes resultados estão em desacordo com os resultados eletroquímicos no meio alcalino em que o eletrocatalisador PtSn/C-ITO 50:50 obteve destaque nos resultados. Estas diferenças podem estar relacionadas a temperatura da célula unitária e também com a normalização por massa de Pt na hora de se efetuar a pintura dos eletrodos para a produção do MEA.

As análises eletroquímicos são realizados em temperatura ambiente, enquanto os experimentos em célula unitária trabalham com uma temperatura de $100^{\circ} \mathrm{C}$. A normalização por massa faz com que o eletrocatalisador PtSn/C- 
ITO 50:50 tenha mais massa por $\mathrm{cm}^{2}$ no eletrodo do MEA, fazendo-se então necessário uma maior quantidade do eletrocatalisador preparado para se obter quantidades de Pt proporcionais aos demais. Isto pode levar a uma maior resistência ôhmica e também a tornar os sítios de Pt menos disponíveis para adsorção do combustível.

Um outro fator que fortalece a diferença nos resultados entre as análises eletroquímicos e os experimentos em célula unitária em meio alcalino é a similaridade nas análises de voltametria cíclica com etanol mostrando que a adição de Sn e ITO não demonstram variação significativa de atividade eletródica, levando a crer que que o mecanismo de oxidação do etanol é diferente em meio alcalino sendo necessário um estudo sobre o mecanismo de oxidação do etanol sobre os materiais $\mathrm{PtSn} / \mathrm{C}$ e PtSn/C-ITO e suas composições ótimas.

\subsection{Meio ácido $\mathrm{x}$ meio alcalino}

Ao se comparar as correntes obtidas e os potenciais de início de oxidação nas voltametrias cíclicas para a reação de oxidação de etanol, claramente, as correntes mais altas e os menores potenciais de início de oxidação foram observadas no meio alcalino.

A literatura retrata dois fenômenos que explicam essa superioridade em meio alcalino. O primeiro se deve à ausência de sulfatos provenientes do ácido sulfúrico no meio alcalino, que se adsorve na Pt deixando assim seus sítios mais impedidos [88]. O segundo reporta a disponibilidade de íons $\mathrm{OH}$ adsorvidos em potenciais mais baixos, que auxiliam a remoção de etóxidos e outros intermediários durante a reação de oxidação do etanol [89].

A TAB. 12 mostra os valores de corrente para oxidação do etanol após 30 minutos de operação para os eletrocaltalisadores Pt/C, Pt/C-ITO, PtSn/C 70:30, $\mathrm{PtSn} / \mathrm{C}$-ITO 50:50, PtSn/C-ITO 70:30 e PtSn/C-ITO 90:10 fixados em um potencial de $0,5 \mathrm{~V}$ para o meio ácido e - $0,4 \mathrm{~V}$ para o meio alcalino. 
TABELA 12. Comparação dos valores de oxidação após 30 minutos de operação pela técnica de cronoamperometria do meio ácido com o meio alcalino para os eletrocatalisadores Pt/C, Pt/C-ITO, PtSn/C70:30, PtSn/C-ITO 50:50, PtSn/C-ITO 70:30 e PtSn/C-ITO 90:10.

\begin{tabular}{|c|c|c|}
\hline Eletrocatalisador & Meio ácido $/ \mathrm{A} \mathrm{g}^{-1} \mathrm{Pt}$ & Meio alcalino $\mathrm{I} / \mathrm{A} \mathrm{g}^{-1} \mathrm{Pt}$ \\
\hline $\mathrm{Pt} / \mathrm{C}$ & 0,43 & 1,86 \\
\hline Pt/C-ITO & 3,18 & 2,92 \\
\hline PtSn/C 70:30 & 3,01 & 2,43 \\
\hline PtSn/C-ITO 50:50 & 1,87 & 3,22 \\
\hline PtSn/C-ITO 70:30 & 4,62 & 2,85 \\
\hline PtSn/C-ITO 90:10 & 3,63 & 2,95 \\
\hline
\end{tabular}

Verificou-se que o eletrocatalisador PtSn/C-ITO 70:30 em meio ácido apresentou maior valor de corrente ao final da análise, sendo, portanto, o mais ativo entre todos. Para a análise de cronoamperometria, todos os eletrocatalisadores se beneficiaram da adição do ITO e do Sn quando comparados ao eletrocatalisador de Pt/C. No entanto é importante afirmar que a platina sofre uma menor desativação em meio alcalino quando comparada ao meio ácido. Este efeito pode estar associado a interação de sítios de platina com espécies $\mathrm{OH}$ do meio reacional. Para os sistemas PtSn/C-ITO os valores de correntes são maiores em meio ácido em comparação com meio alcalino indicando que estes sistemas são mais efetivos neste meio racional estudado, portanto o excesso de espécies $\mathrm{OH}$ no meio alcalino pode prejudicar $\mathrm{o}$ desempenho destes eletrocatalisadores tendo em vista que as espécies $\mathrm{OH}$ podem adsorver nos sítios de platina, situação que leva a limitar novas adsorções de moléculas de etanol a temperatura ambiente. 


\section{CONCLUSÕES}

O método da redução via borohidreto, foi efetivo para a produção de eletrocatalisadores em estudo para a eletro-oxidação do etanol.

Os resultados de EDX mostraram que os valores das razões atômicas Pt/C, Pt/C-ITO, PtSn/C 70:30, PtSn/C-ITO 70:30 e PtSn/C-ITO 90:10 são similares aos valores nominais, exceto o catalisador de PtSn/C-ITO 50:50 que apresentou uma composição experimental de aproximadamente 60:40

Os difratogramas de raios $X$ dos eletrocatalisadores $\mathrm{Pt} / \mathrm{C}, \mathrm{Pt} / \mathrm{C}-\mathrm{ITO}$, PtSn/C-ITO 50:50, PtSn/C 70:30, PtSn/C-ITO 70:30 e PtSn/C-ITO 90:10 mostraram uma estrutura cúbica de face centrada, característica do metal platina. Para os sistemas com ITO e Sn foi observado a presença de seus respectivos óxidos (óxidos de estanho e índio para catalisadores com ITO e óxidos de estanho para o catalisador $\mathrm{PtSn} / \mathrm{C}$ 70:30), onde observou-se pelo difratograma a estrutura cúbica do $\ln _{2} \mathrm{O}_{3}$. Foi possível verificar também que com o aumento da quantidade de estanho nos eletrocatalisadores preparados, aumentou-se o parâmetro de rede da Pt.

Nas análises eletroquímicas, os eletrocatalisadores em meio ácido mostraram boa concordância com os resultados obtidos nos experimentos em célula unitária em que o eletrocatalisador PtSn/C-ITO 70:30 apresentou melhor performance estando de acordo com alguns pesquisadores que afirmam uma razão ótima de 3:1 para eletrocatalisadores de PtSn/C.

As análises eletroquímicas em meio alcalino apresentaram resultados divergentes aos experimentos em célula unitária no qual a justificativa pode estar relacionada a um mecanismo diferente de oxidação do etanol comparado ao mecanismo que ocorre em meio ácido, ao uso de temperatura nos experimentos em célula unitária e a normalização por massa de platina para a pintura dos eletrodos na confecção do ânodo no MEA.

O uso do ITO mostrou-se efetivo nas análises eletroquímicas tanto para o meio ácido quanto para o meio alcalino quando comparados ao eletrocatalisador $\mathrm{Pt} / \mathrm{C}$. Entretanto, vale salientar que um estudo sobre quantidade de ITO utilizado no suporte seria benéfico para otimização 
eletrocatalítica já que foi usado um valor fixo de 15\% dentro do suporte de carbono Vulcan XC 72. 


\section{REFERÊNCIAS BIBLIOGRÁFICAS}

[1] FARIAS, M.L; SELLITTO, A.M. Uso da energia ao longo da história: evolução e perspectivas futuras. Revista Liberato. Novo Hamburgo. v. 12, n. 17, p. 01-10. 2011.

[2] WILSON, M. A Energia. Rio de Janeiro.: Livraria José Olympio Editora, 1967.

[3] LINARDI, M. Introdução à Ciência e Tecnologia de Células a Combustível. 1.ed. São Paulo.: Artiliber, 2010.

[4] TICIANELLI, E.A.; GONZALEZ, E.R. Eletroquímica. 2.ed. São Paulo.: Editora da Universidade de São Paulo, EDUSP, 2013.

[5] GAO, L.; ABEYSIRI, M. C.; WINFIELD, Z. C. Evaluating the Energy Consumption and Emissions of Direct Alcohol Fuel Cells. International Journal of Energy Science. v.2, p. 211-216, 2012.

[6] Ministério da Agricultura. Cana de açúcar. 2015 Disponível em: $<$ http://www.agricultura.gov.br/vegetal/culturas/cana-de-acucar> Acesso em: 13 jul. 2015.

[7] VIGIER, F.; COUTANCEAU, C.; PERRARD, A.; BELGSIR, E.M.; LAMY, C. Development of anode catalysts for a direct ethanol fuel cell. J. Appl. Electrochem. v.34, p. 439-446, 2004.

[8] SOUZA, J. P. I.; RABELO, F. J. B.; MORAES, I. R.; NART, F. C. Performance of a co-electrodeposited Pt-Ru electrode for the electrooxidation of ethanol studied by in situ FTIR spectroscopy. J. of Electroanalytical Chemistry, v.420, p.17-20, 1997.

[9] KOWAL, A.; LI, M.; SHAO, M.; SASAKI, K.; VUKMIROVIC, M.B.; ZHANG, J.; MARINKOVIC, N. S.; LIU, P.; FRENKEL, A. I.; ADZIC, R. R. Ternary $\mathrm{Pt} / \mathrm{Rh} / \mathrm{SnO}_{2}$ electrocatalysts for oxidizing ethanol to $\mathrm{CO}_{2}$. Nature Materials. v.8, p.325-330, 2009. 
[10] NETO, A. O.; LINARDI, M.; ANJOS, D. M.; TREMILIOSI-FILHO, G.; SPINACÉ, E. V. Electro-oxidation of ethanol on $\mathrm{PtSn} / \mathrm{CeO}_{2}-\mathrm{C}$ electrocatalyst. J. Appl Electrochem. v.39, p.1153-1156, 2009.

[11] LAMY, C.; ROUSSEAU, S.; BELGSIR, E.M.; COUNTECEAU, C.; LÉGER, J. M. Recent progress in the direct ethanol fuel cell: development of new platinum-tin electrocatalysts. Electrochim. Acta. v.49, p.3901-3908, 2004.

[12] ZHOU, W.; ZHOU, Z.; SONG, S.; LI, W.; SUN, G.; TSIAKARAS, P.; XIN, Q. Pt based anode catalysts for direct ethanol fuel cells. Appl. Catal. B Environ. v.46, p.273-285, 2003.

[13] ZHOU, W.J.; ZHOU, B.; LI, W.Z.; ZHOU, Z.H.; SONG, S.Q.; SUN, G.Q.; XIN, Q.; DOUVARTZIDES, S.; GOULA, M.; TSIAKARAS, P.

Performance comparison of low-temperature direct alcohol fuel cells with different anode catalysts. J. Power Sources. v.126, p.16-22, 2004.

[14] ZHOU, W.J.; LI, W.Z.; SONG, S.Q.; ZHOU, Z.H.; JIANG, L.H.; SUN, G.Q.; XIN, Q.; POULIANITIS, K.; KONTOU, S.; TSIAKARAS, P. Bi- and tri-metallic Pt-based anode catalysts for direct ethanol fuel cells. $J$.

Power Sources. v.131, p.217-223, 2004.

[15] WANG, Y.; ZOU, S.; CAI, W. B. Recent Advances on Electro-Oxidation of Ethanol on Pt- and Pd-Based Catalysts: From Reaction Mechanisms to Catalytic Materials. Catalysts, v.5, p.1507-1534, 2015.

[16] PARRONDO, J.; SANTHANAM, R.; MIJANGOS, F.; RAMBABU, B. Electrocatalytic Performance of $\ln _{2} \mathrm{O}_{3}$-Supported Pt/C Nanoparticles for Ethanol Electro-oxidation in Direct Ethanol Fuel Cells. Int. J.

Electrochem. Sci. v.5, p.1342, 2010.

[17] SPINACÉ, E. V.; DIAS, R.R.; BRANDELISE, M.; LINARDI, M.; NETO, A.O. Electrooxidation of ethanol using PtSnRh/C electrocatalysts prepared by an alcohol-reduction process. Ionics. v.16, p.91, 2010. 
[18] NETO, A.O.; BRANDELISE, M.; DIAS, R.R.; AYOUB, J.M.S.; SILVA, A.C.; PENTEADO, J.C.; LINARDI, M.; SPINACÉ, E.V. The performance of $\mathrm{Pt}$ nanoparticles supported on $\mathrm{Sb}_{2} \mathrm{O}_{5} . \mathrm{SnO}_{2}$, on carbon and on physical mixtures of $\mathrm{Sb}_{2} \mathrm{O}_{5} . \mathrm{SnO}_{2}$ and carbon for ethanol electro-oxidation. International Journal of hydrogen energy. v.35, p. 9177, 2010.

[19] CHU, D.; WANG, J.; WANG, S.; ZHA, L.; HE, J.; HOU, Y.; YAN, Y.; LIN, $\mathrm{H}$.; TIAN, Z. High activity of $\mathrm{Pd}-\ln _{2} \mathrm{O}_{3} / \mathrm{CNTs}$ electrocatalyst for electrooxidation of ethanol. Catalysis Communications; v.10, p.955, 2009.

[20] PARK, I.S.; LEE, E.; MANTHIRAM, A. Electrocatalytic Properties of Indium Tin Oxide-Supported Pt Nanoparticles for Methanol Electrooxidation. J. Electrochem. Soc. p. B251, v.157, 2010.

[21] Universidade Federal de Viçosa. Centro de Ciências Agrárias. Célula a Combustível. Departamento de Energia Agrícola. Minas Gerais, 1999.

[22] DADDA, BACHIR.; ABBOUDI, SAID.; ZARRIT, RIDA.; GHEZAL, ABDERRAHMANE. Heat and mass transfer influence on potential variation in a PEMFC membrane. Int. J. Hydrogen Energy. v.39, p.15238-15245, 2014.

[23] WENDT, H.; GÖTZ, M.; LINARDI, M. Tecnologia de células a combustível. Química Nova. v. 23, p. 538-546, 2000.

[24] HARVEY, L.D.D. Energy and the new reality 2: carbon-free energy supply. London.: Earthscan, 2010.

[25] ANANTHACHAR, V.; DUFFY, J.J. Efficiencies of hydrogen storage systems onboard fuel cell vehicles. Solar Energy. v.78, p. 687-694, 2005.

[26] BERGAMASKI, K.; GOMES, J.F.; GOI, B.E.; NART, F.C. Effect of alcohol concentration and electrode composition on the ethanol electrochemical oxidation. Eclética Química, v. 28, p. 87-92, 2003.

[27] CHRISTENSEN, P.A.; JONES, S.W.M.; HAMNETT, A. In situ FTIR studies of ethanol oxidation at polycrystalline $\mathrm{Pt}$ in alkaline solution. $\boldsymbol{J}$. Phys. Chem. C. v.116, p.26109-26109, 2012. 
[28] SPINACÉ, E.V.; VALE, L.A.I.; NETO, A.O.; LINARDI, M. Preparation of $\mathrm{PtRu} / \mathrm{C}$ Anode Electrocatalysts using $\mathrm{NaBH}_{4}$ as Reducing Agent and $\mathrm{OH}-$ íons as Stabilizing Agent. ECS Transactions. v. 5, p. 89-94, 2007.

[29] SILVA, J. C. M.; BUZZO, G. S.; SOUZA, R. F. B.; SPINACÉ, E. V.; NETO, A. O.; ASSUMPÇÃO, M. H. M. T. Enhanced Electrooxidation of Ethanol Using $\mathrm{Pd} / \mathrm{C}+\mathrm{TiO}_{2}$ Electrocatalysts in Alkaline Media.

Electrocatalysis. v.6, p.86-91, 2015.

[30] KIRKLAND, A.I.; HUTCHISON, J.L. Nanocharacterization. 1.ed. Cambridge.: RSC Publishing, 2007.

[31] BONIFACIO, R. N.; NETO, A.O.; LINARDI, M. Influence of the relative volumes between catalyst and Nafion ionomer in the catalyst layer efficiency International Journal of hydrogen energy. v.39, p.14680, 2014.

[32] GONZALEZ, E. Eletrocatálise e poluição ambiental. Química Nova. v.23, p.262-266, 2000.

[33] TICIANELLI, E. A.; CAMARA, G. A.; SANTOS, L. G. R. A. Eletrocatálise das reações de oxidação de hidrogênio e de redução de oxigênio.

Química Nova. v. 28, p. 664-669, 2005.

[34] GONZALEZ, E. R.; TICIANELLI, E. A.; PINHEIRO, A. L. N.; PEREZ, J. Processo de Obtenção de Catalisadores de Platina Dispersa Através da Redução por Ácido. Patente Brasileira INPI - SP, n.9.702.816-9. 1997.

[35] WENDT, H.; SPINACÉ, E.V.; NETO, A.O.; LINARDI, M. Electrocatalysis and electrocatalysts for low temperature fuel cells: fundamentals, state of the art, research and development. Química Nova, v.28, n. 6, p. 10661075, 2005.

[36] LIU, H.; SONG, C.; ZHANG. L.; ZHANG, J.; WANG, H.; WILKINSON, D.P. A review of anode catalysis in the direct methanol fuel cell. Journal of Power Sources, v.155, n. 2, p. 95-110, 2006. 
[37] ZHOU, W.J.; ZHOU, B.; LI, W,Z.; ZHOU, Z.H.; SONG, S.Q.; SUN, G.Q.; XIN, Q.; DOUVARTZIDES, S.; GOULA, M.; TSIAKARAS, P.

Performance comparison of low-temperature direct alcohol fuel cells with diferente anode catalysts. Journal of Power Sources, v. 126, n. 1-2, p. 16-22, 2004.

[38] DOS ANJOS, D.M. Preparação, caracterização e estudo eletroquímico de ligas $P t / M$ e $P t / M_{1} M_{1}\left(M_{1} M_{1}=M o\right.$, Sn, Ru, Os e W) para eletrooxidação de etanol com aplicações em DEFC. 2007. Tese (Doutorado) - Universidade de São Paulo - Instituto de Química de São Carlos.

[39] BORGES, J. Desenvolvimento de catalisadores nanoparticulados do tipo Pt-M1-M2 (M1 e M2 = Sn e Re) para aplicação em células a combustível direta de etanol. 2008. Dissertação (Mestrado) Universidade de São Paulo - Instituto de Química de São Carlos.

[40] ZHU, M. Y.; SUN, G. Q.; YAN, S. Y.; LI, H. Q.; XIN, Q. Preparation, Structural Characterization, and Activity for Ethanol Oxidation of CarbonSupported PtSnIn Catalyst. Energy \& Fuels. v.23, p.403-407, 2009.

[41] DE SOUZA, R. F. B.; FLAUSINO, A. E. A.; RASCIO, D. C.; OLIVEIRA, R. T. S.; NETO, E. T.; CALEGARO, M. L.; SANTOS, M. C. Ethanol oxidation reaction on $\mathrm{PtCeO}_{2} / \mathrm{C}$ electrocatalysts prepared by the polymeric precursor method. Applied Catalysis B: Environmental. v.91, p.516-523, 2009.

[42] ZOLADEK, S.; RUTKOWSKA, I. A.; KULESZA, P. J. Enhancement of activity of platinum towards oxidation of ethanol by supporting on titanium dioxide containingphosphomolybdate-modified gold nanoparticles.

Applied Surface Science. v.257, p.8205-8210, 2011.

[43] DE SOUZA, R.F.B.; SILVA, J.C.M.; ASSUMPÇÃO, M.H.M.T.; NETO, A.O.; SANTOS, M.C. Ethanol Oxidation Reaction Using PtSn/C+Ce/C Electrocatalysts: Aspects of Ceria Contribution. In Electrochimica Acta. v.117, p. 292-298, 2014. 
[44] COLMATI, F.; ANTOLINI, E.; GONZALEZ, E. R. Ethanol oxidation on a carbon-supported Pt75Sn25 electrocatalyst prepared by reduction with formic acid: Effect of thermal treatment. Applied Catalysis B:

Environmental. v.73, p.106-115, 2007.

[45] PURGATO, F. L. S.; OLIVI, P.; LÉGER, J. M.; DE ANDRADE, A. R.; TREMILIOSI-FILHO, G.; GONZALEZ, E. R.; LAMY, C.; KOKOH, K. B., Activity of platinum-tin catalysts prepared by the Pechini-Adams method for the electrooxidation of ethanol. Journal of Electroanalytical Chemistry. v.628, p.81-89, 2009.

[46] LIU, J.; CAO, J.; HUANG, Q.; LI, X.; ZOU, Z.; YANG, H., Methanol oxidation on carbonsupported Pt-Ru-Ni ternary nanoparticle electrocatalysts. Journal of Power Sources. v.175, p.159-165, 2008.

[47] FREITAS, K.S. Eletrocatalisadores de ligas de platina dispersos em substratos de óxidos para a reação de oxidação de hidrogênio puro e na presença de CO. 2009. Tese (Doutorado) - Instituto de Química de São Carlos, da Universidade de São Paulo.

[48] ZHU, M.; SUN, G.; XIN, Q. Effect of alloying degree in PtSn catalyst on the catalytic behavior for ethanol electro-oxidation. In Electrochimica Acta. v.54, p.1511-1518, 2009.

[49] LIMA, F.H.B.; GONZALEZ, E.R. Ethanol electro-oxidation on carbonsupported Pt-Ru, Pt-Rh and Pt-Ru-Rh nanoparticles. Electrochimica Acta, v. 53, n. 6, p. 2963-2971, 2008.

[50] LIU, H., SONG, C., ZHANG, L., ZHANG, J., WANG, H., WILKINSON, J. A. Review of Anode Catalysis in the Direct Methanol Fuel Cell. J. Power Sources, v. 155, p. 95-110, 2006.

[51] COUTANCEAU, C.; et al. Review of different methods for developing nanoelectrocatalysts for the oxidation of organic compounds.

Electrochimica Acta. v.53, p. 6865-6880, 2008. 
[52] SPINACE, E. V.; et al. Métodos de preparação de nanopartículas metálicas suportadas em carbono de alta área superficial, como eletrocatalisadores em células a combustível com membrana trocadora de prótons. Química Nova. São Paulo. v.27, n. 4, p. 648-654, 2004.

[53] CALEGARO, M.L.; et al. Preparation, characterization and utilization of a new electrocatalyst for ethanol oxidation obtained by the sol-gel method. J. Power Sources. v.156, p.300-305, 2006.

[54] WAYNE RASBAND. Image J, version 1.50 i: National Institutes of Health, 1997-2016.

[55] GOMES, W. S.; SILVA, U. L. V.; SOUZA, J. P. I. Influência do método de preparação de eletrocatalisadores $\mathrm{PtRu} / \mathrm{C}$ sobre a atividade catalítica frente à reação de oxidação de etanol em meio ácido. Química Nova. São Paulo. v. 36, n. 4, p. 507-512, 2013.

[56] HYUN, M. S.; et al. Effect of $\mathrm{NaBH}_{4}$ concentration on the characteristics of $\mathrm{PtRu} / \mathrm{C}$ catalyst for the anode of DMFC prepared by the impregnation method. Catalysis Today. v.132, p.138-145, 2008.

[57] CHANG, J.; et al. Bimetallic nanoparticles of copper and indium by borohydride reduction. Thin Solid Films, v.519, p. 2176-2180, 2011.

[58] HENRIQUE, R.S.; DE SOUZA, R.F.B.; SILVA, J.C.M.; Ayoub, J.M.S.; PIASENTIN, R.M.; LINARDI, M.; SPINACÉ, E.V.; SANTOS, M.C.; NETO, A.O. Preparation of $\mathrm{Pt} / \mathrm{C}-\mathrm{In}_{2} \mathrm{O}_{3}$ center dot $\mathrm{SnO}_{2}$ electrocatalysts by borohydride reduction process for ethanol electro-oxidation. Int. J. Electrochem. Sci. v.7, p.2036-2046, 2012.

[59] NETO, A.O.; TUSI, M.M.; OLIVEIRA, P.N.S.; SILVA, S.G.; COELHO, S. M.; SPINACÉ, E.V. PdBi/C electrocatalysts for ethanol electro-oxidation in alkaline medium. Int. J. Hydrogen Energy. v.36, p.10522-10526, 2011.

[60] ZHOU, W.; et al. Pt based anode catalyst for direct ethanol fuell cells. Appl.Catal.B:Environ. v.46, p.273-285, 2003. 
[61] NETO, A.O. Eletro-oxidação de etanol sobre eletrocatalisadores PtRh/C, $\mathrm{PtSn} / \mathrm{C}$ e PtSnRh/C preparados pelo método da redução por álcool. Eclética Química. v.31, p. 81-88, 2006.

[62] CULLITY, B.D. In Elements of X-Ray Diffraction. Addison Wesley Publishing Co. 1980.

[ 63] BARRETA, L.F.N. Estudo da reação de redução de oxigênio em meio ácido em eletrocatalisadores de platina e paládio disperses em carbono. 2009. Dissertação (Mestrado) - Instituto de Química de São Carlos, da Universidade de São Paulo.

[64] PIASENTIN, R.M.; et al. Electro-oxidation of Ethanol on PtPdSn/C$\mathrm{Sb}_{2} \mathrm{O}_{5} . \mathrm{SnO}_{2}$ electrocatalysts prepared by borohydride reduction. International Journal of Electrochemical Science. v.8, p. 435-445, 2013.

[65] BORTHOLIN, E.C. Preparação de ligas binárias e ternárias de Pt, We Os para a oxidação de metanol em células a combustível de baixa temperatura. 2006. Tese (Doutorado) - Instituto de Química de São Carlos, da Universidade de São Paulo.

[66] LAMY, C.; ROUSSEAU, S.; BELGSIR, E.M.; COUTANCEAU, C.; LÉGER, J.-M. Recent progress in the direct ethanol fuel cell: development of new platinum-tin electrocatalysts. Electrochimica Acta. v. 49, n. 22-23, p. 3901-3908, 2004.

[67] WU, J.; YUAN, X.Z.; WANG, H.; BLANCO, M.; MARTIN, J.J.; ZHANG, J. Diagnostic tools in PEM fuel cell research: Part I Electrochemical techniques. International Journal of Hydrogen Energy, v. 33, n. 6, p. 1735-1746, 2008.

[68] PECHINI, M.P. Method of Preparing Lead and Alkaline-earth Titanates and Niobates and Coating Method Using the Same to form Capacitors, US Patent no 3330697, 1967.

[69] LESSING, P. A. Mixed-cation oxide powders via polymeric precursors. Am. Ceram. Soc. Bull. v. 68, p.1002-1007, 1989. 
[70] GONZALEZ, E.R.; TICIANELLI, E.A.; PINHEIRO, A.I.N.; PEREZ, J. Brazilian Patent, INPI-SP no. 00321. 1997

[71] TAYAL, J.; RAWAT, B.; BASU, S. Bi-metallic and tri-metallic Pt-Sn/C, $\mathrm{Pt}-\mathrm{Ir} / \mathrm{C}, \mathrm{Pt}-\mathrm{Ir}-\mathrm{Sn} / \mathrm{C}$ catalysts for electro-oxidation of ethanol in direct ethanol fuel cell. Int. J. Hydrogen Energy. v.36, p.14884-14897, 2011.

[72] OTTONI, C. A.; RAMOS, C. E. D.; GOMES, S. S.; SPINACÉ, E. V.; BRAMBILLA, S. R. F.; NETO, A. O. Glycerol and Methanol Electrooxidation at Pt/C-ITO under Alkaline Condition. Electroanalysis. v.28, p.2552-2558, 2016.

[73] DE SOUZA.; et. al. Study of etanol electrooxidation in acid environment on $\mathrm{Pt}_{3} \mathrm{Sn} / \mathrm{C}$ anode catalysts prepared by a modified polymeric precursor method under controlled synthesis conditions. Journal of Power Sources. v.195, p.1589-1593, 2010.

[74] HENRIQUE, R.S.; et. al. Preparation of $\mathrm{Pt} / \mathrm{C}-\mathrm{In}_{2} \mathrm{O}_{3} . \mathrm{SnO}_{2}$ Electrocatalysts by Borohydride Reduction Process for Ethanol Electro-Oxidation. Int. J. Electrochem. Sci. v.7, p.2036-2046, 2012.

[75] ZHOU, W.; et al. Direct ethanol fuel cells based on PtSn anodes: the effect of Sn content on the fuel cell performance. Journal of Power Sources. v.140, p.50-58, 2005.

[76] JIANG L.; et. Al. Preparation and characterization of PtSn/C anode electrocatalysts for direct ethanol fuel cell. In Catalysis Today. v.93-95, p.665-670, 2004.

[77] YONGLANG, G.; YANZHEN, Z.; MEIHUA, H. Enhanced activity of $\mathrm{PtSn} / \mathrm{C}$ anodic electrocatalyst prepared by formic acid reduction for direct ethanol fuel cells. In Electrochimica Acta. v.53, p.3102-3108, 2008.

[78] DONG-HA LIM.; DONG-HYEOK CHOII.; WEON-DOO LEE.; HO-IN LEE. A new synthesis of a highly dispersed and $\mathrm{CO}$ tolerant $\mathrm{PtSn} / \mathrm{C}$ electrocatalyst for low-temperature fuel cell; its electrocatalytic activity and long-term durability. In Applied Catalysis B: Environmental. v.89, p.484-493, 2009. 
[79] SPINACÉ, E.V.; LINARDI, M.; NETO, A.O. Co-catalytic effect of nickel in the electro-oxidation of ethanol on binary Pt-Sn electrocatalysts. In Electrochemistry Communications. v.7, p.365-369, 2005.

[80] VIGIER, F.; COUTANCEAU, C.; HAHN, F.; BELGSIR, E.M.; LAMY, C. On the mechanism of ethanol electro-oxidation on Pt and PtSn catalysts: electrochemical and in situ IR reflectance spectroscopy studies. In Journal of Electroanalytical Chemistry. v. 563, p.81-89, 2004.

[81] JIANG L.; et al. Structure and chemical composition of supported Pt-Sn electrocatalysts for ethanol oxidation. In Electrochimica Acta. v. 50, p.5384-5389, 2005.

[82] KIM, J. H.; CHOI, S. M.; NAM, S. H.; SEO, M. H.; CHOI, S. H.; KIM, W. B. Influence of Sn content on PtSn/C catalysts for electrooxidation of C1C3 alcohols: Synthesis, characterization, and electrocatalytic activity. Applied Catalysis B: Environmental. v.82, p.89-102, 2008.

[83] LIM, D.-H.; CHOI, D.-H.; LEE, W.-D.; LEE, H.-I. A new synthesis of a highly dispersed and $\mathrm{CO}$ tolerant $\mathrm{PtSn} / \mathrm{C}$ electrocatalyst for lowtemperature fuel cell; its electrocatalytic activity and long-term durability. Applied Catalysis B: Environmental. v.89, p.484-493, 2009.

[84] KLOKE, A.; VON STETTEN, F.; ZENGERLE, R.; KERZENMACHER, S. Strategies for the Fabrication of Porous Platinum Electrodes. Advanced Materials. v. 23, p. 4976-5008, 2011.

[85] CRISAFULLI, R.; ANTONIASSI, R.M.; NETO, A. O.; SPINACÉ, E.A. Acid-treated $\mathrm{PtSn} / \mathrm{C}$ and $\mathrm{PtSnCu} / \mathrm{C}$ electrocatalysts for ethanol electrooxidation. In International Journal of Hydrogen Energy. v.39, p.56715677, 2014.

[86] FENG, Y.; WANG, C.; BIN, D.; ZHAI, C.; REN, F.; YANG, P.; DU, Y. One-pot Synthesis of PtSn Bimetallic Composites and Their Application as Highly Active Catalysts for Ethanol Electrooxidation.

ChemPlusChem. v.81, p.93-99, 2016.

[87] ANTOLINI, E.; GONZALEZ, E.R. The electro-oxidation of carbon monoxide, hydrogen/carbon monoxide and methanol in acid medium on 
Pt-Sn catalysts for low-temperature fuel cells: A comparative review of the effect of Pt-Sn structural characteristics. In Electrochimica Acta. v.56, p.1-14, 2010.

[88] TRIPKOVIC, D.V.; STRMCNIK, D.; VAN DER VLIET, D.; V. STAMENKOVIC, V.N.M. The role of anions in surface electrochemistry. Markovic Faraday Discuss. v.140, p.25-40, 2009.

[89] JIANG, L.; HSU, A.; CHU, D.; CHEN, R. Ethanol electro-oxidation on $\mathrm{Pt} / \mathrm{C}$ and $\mathrm{PtSn} / \mathrm{C}$ catalysts in alkaline and acid solutions. In International Journal of Hydrogen Energy. v.35, p.365-372, 2010.

[90] RIZO, R.; SEBASTIÁN, D.; Lázaro, M.J.; Pastor, E. On the design of PtSn efficient catalyst for carbon monoxide and ethanol oxidation in acid and alkaline media. In Applied Catalysis B: Environmental. v.200, p.246-254, 2017. 